\title{
The Cult of Hecate in Lydia: Evidence from the Manisa Museum
}

\author{
N. Eda AKYÜREK ȘAHİN*
}

This paper is dedicated to the memory of my husband Professor Dr. Sencer Şahin

The French epigraphist and philologist L. Robert, who had a deep knowledge not only of Greek and Latin epigraphy, but also of ancient history, mythology and classical cultures, stated in one of his papers in 1955 that the cult of Hecate ${ }^{1}$ was documented quite rarely in the region of Lydia. ${ }^{2}$ Robert points out that there is no mention of Hecate in the significant contribution of J. Keil regarding the cults of Lydia, entitled 'Die Kulte Lydiens'3 published in 1923. ${ }^{4} \mathrm{He}$ also emphasized that there were

\footnotetext{
${ }^{\otimes}$ Prof. Dr. N. Eda Akyürek Şahin, Akdeniz University, Faculty of Letters, Dept. of Ancient Languages and Cultures, Campus 07058 Antalya (edasahin@akdeniz.edu.tr).
}

In August 2005 I had the chance to work in the Manisa Museum and to record the monuments which I introduce in this paper. I am grateful to the authorities of the Ministry of Culture and Tourism, the General Directorate for Cultural Assets and Museums for the permission granted to work on the Hecate monuments in the museum. I thank Ms Müesser Tosunbaş, the director of the museum who permitted and supported my work in the museum and also the archaeologist, Sevgi Soyeker. I also thank my assistant Hüseyin Uzunoğlu, who translated this paper into English and Michael P. Duggan and for polishing the translation. I would also like to thank Charlotte Roueché for her substantial support.

${ }^{1}$ My research work for the corpus of the monuments concerning the cult of Hecate in Asia Minor is still in progress. On one hand, I am still collecting the documents regarding the cult; on the other hand, I have started publishing some of the monuments. For the already published articles see Akyürek Şahin 2006; Akyürek Şahin 2007, 92-94 no. 67-69; Akyürek Şahin 2011. In addition, I am preparing all the Hecate monuments in the museums of Kütahya, Afyon, Eskişehir, Uşak, Efes, İzmir and Bodrum to be published soon. This article was actually prepared for the Festschrift of my husband Sencer Şahin prior to his sudden death in 2014. Since the publication of the memorial volume has regrettably been so much delayed and for other reasons, I withdrew my paper from that volume. The Hecate statuettes and the reliefs in the Manisa museum treated here are now also published in the Sculpture Catalogue of Manisa Museum; see Durugönül et al. 2015, 140150. I provided the editors of the Catalogue with the relevant material in order that they could use it for their studies. However, since the publication of my contribution is somewhat late, these monuments, which should have been published first here, have already been included in their catalogue. I express my sincerest thanks to Prof. Dr. Serra Durugönül (Mersin University), one of the editors and authors of that volume, for sharing her ideas with me. She read my article critically and made some valuable suggestions and corrections especially concerning my archaeological terms and discussions. I would also like to thank Asst. Prof. Dr. Münteha Dinç (Uşak University), who helped identify the male figure in no. 1 as Men and also provided me with the relevant literature cited in cat. no. 1.

${ }^{2}$ Robert, Hellenica X, 1955, 115: 'Les documents du culte d'Hécate sont rares en Lydie.' See also Kraus 1960, 52 fn. 249; Akyürek Şahin 2006, 65 fn. 6.

${ }^{3}$ See Keil 1923. On the content of the article see Hanfmann 1983, 219; Petzl 1995, 37-38; Paz de Hoz 1999, 1-2; Petzl 2002, 381; Petzl 2003, 93. 
no votive inscriptions to Hecate in Lydia. In that article Robert published the stele, presented here as cat. no. 7 , citing only a few documents known at that time. ${ }^{5}$ Over the course of time, however, new monuments associated with Hecate in Lydia have been published, and other relevant objects have been brought to the Manisa museum. The aim of this paper is to provide a survey of the cult of Hecate in Lydia as well as of its geographical distribution within the region. For this I will make use of both new and already published material in the Museum of Manisa, but I will also fall back on monuments which do not have any connection with this museum.

Because of the limited evidence, the cult of Hecate in Lydia has to date not been the subject of a major study, although relevant documetns have been published in other collections. In terms of ancient Greek inscriptions Lydia is one of the richest regions in Asia Minor. In comparison with other regions of Asia Minor ${ }^{6}$ the inscriptions of the region have also been more intensively studied and many corpora have already been published. The vast quantity of epigraphic material now published has enabled a move to more specific studies, for example onthe religious structures and cults of the region. As early as 1923, so many inscriptions ${ }^{7}$ were known that J. Keil could present the important study mentioned above providing a general overview of the regional cults through dividing them into groups according to their place of origins. Due to the large number of new documents recovered since Keil's publication and new data obtained from them, an overall re-evaluation of the Lydian cults has become unavoidable and M. Paz de Hoz, almost eighty years after Keil's paper and still following Keil's methodology published a doctoral dissertation on the issue in $1999 .{ }^{8}$

${ }^{4}$ Robert, Hellenica X, 1955, 115 fn. 1 . The name of Hecate is not even mentioned in Keil's article. This is a clear indication that no epigraphic documents concerning the cult were known prior to 1923.

${ }^{5}$ There are some monuments which Robert overlooked, see for instance no. 15. Robert refers to the Hecate monuments in other regions, primarily in Phrygia, see Robert, ibid., 115-116. He also noted that he was much impressed by the contrast between the abundance of records concerning Hecate in Phrygia and their rarity in Lydia, see ibid. 115, fn. 2, esp. the last sentence. Cf. Kraus 1960, 52 fn. 249.

${ }^{6}$ See for example Buckler - Robinson 1932; Herrmann 1962; Herrmann - Polatkan 1961; Robert 1964; Herrmann - Polatkan 1969; IMagnesia; Naour 1981; Herrmann, TAM V 1; Herrmann, TAM V 2; Gauthier 1989; Malay 1994; Petzl 1994; Malay 1999; Petzl, TAM V 3 (The older publications are not cited here).

${ }^{7}$ In his paper, Keil relied on 354 inscriptions from Lydia. For the comments on it, see Schuler 2002, 458. On the epigraphic richness of the region, especially of the area of the 'Katakekaumene', see Herrmann - Varinlioğlu 1984, 1 .

${ }^{8}$ In general see, Paz de Hoz 1999. In contrast to Keil's paper, more than 800 inscriptions with regard to religion and cult are used in this book. The general results of her study are: Inscriptions providing evidence for cult in Lydia date mostly from the Hellenistic and Roman Periods; yet the overwhelming majority of the extant inscriptions date from the Roman Imperial Age, i.e. from the first three centuries A.D. (although one should keep in mind that the inscriptions known till now are only a small part of the total quantity). The religious practices and cults in Lydia differ from area to area, such as the northwest, the northeast, and the central part of Lydia extending to the east and the Caystros Valley. Due to its rough terrain, the eastern part of the region became Hellenized much later, whereas central Lydia and the sites in the Caystros Valley obviously were Hellenized as well as urbanised from the Hellenistic Age onwards. With the Hellenization of the western parts of Lydia the cults practised there also came under Greek influence. The striking point in the cultic inscriptions of the region is that the cult practices had a general, public and official character supported and executed by the authorities, which is reflected in the inscriptions. The eastern parts of Lydia show the contrary. Here, the traditional local Anatolian gods are still dominant in the religious beliefs and cults, with the in- 
Although the study of Paz de Hoz has been criticized, ${ }^{9}$ it is both a valuable and a fundamental study in terms of having provided an comprehensive view of the Lydian cults ${ }^{10}$ and reached new conclusions; it is now easy to find all the inscriptionsrelevant to the cults of the region. ${ }^{11}$ But anyone looking for Hecate in this study will quickly realise that with the exception of one new document there is little new information since L. Robert's compilation. ${ }^{12}$ The only inscription concerning the cult of Hecate presented by Paz de Hoz (a verse prayer for Hecate; here cat. no. 6) was published by Herrmann and Polatkan in $1961 .{ }^{13}$ That inscription was indeed to that date the only epigraphic document on Hecate in Lydia. However, a second inscription regarding Hecate (here cat. no. 8) was published by H. Malay in 1999, already after the study of Paz de Hoz, so that this document was not included and discussed in her work. ${ }^{14}$ Except for these two inscriptions, no inscribed documents for the cult of Hecate in Lydia are known at present, whereas some uninscribed monuments relating directly to the goddess are available, most of which are preserved in the museum of Manisa. ${ }^{15}$ Below I present the catalogue of monuments concerning the cult of Hecate in Lydia; I have in-

scriptions mostly reflecting the personal beliefs of the people and the communities. Generally speaking, the Hellenization of the Lydian cults is seen mostly in the cities, while local gods and syncretic gods appear in the countryside. The study of inscriptions with religious content throughout the region of Lydia allows us to say that Anatolian gods are named far more than the gods of Greek origin. The religious beliefs and cults of other cultures which could influence Lydia appear not to have become dominant, notwithstanding the traces they left in the region. The dominance of the local Anatolian gods in eastern Lydia only started to decrease when Christianity became widespread. Furthermore, the intense syncretism of local Anatolian, Greek, Persian and other gods is a noteworthy phenomenon of the region.

${ }^{9}$ See Schuler 2002. Schuler objects that in this book the inscriptions are unnecessarily compiled in a comprehensive and detailed catalogue, that the material in this catalogue is not really used and not sufficiently assessed by the author and that many important issues are omitted. In his opinion, the book contains major flaws and does not meet his expectations.

${ }^{10}$ Emperor worship and Christianity in Lydia are excluded in Paz de Hoz's book; only the pagan cults are examined.

${ }^{11}$ Providing researchers with an opportunity for a quick view of the material, this catalogue serves a very useful purpose for those who work on Lydian cults. Therefore, as opposed to the opinion of Schuler, I think that M. Paz de Hoz deserves praise for collecting these inscriptions. It would likewise be very beneficial to research other regions rich in cultic documents. For example, corpora of inscriptions concerning the gods and cults of Ionia, Caria, Lycia, Pamphylia, Bithynia, Phrygia etc. are still lacking. There are so many different religious landscapes in ancient Asia Minor, and the panthea of the more than 400 cities differ significantly from each other so that it is very difficult to get an overview. Beside the coins the inscriptions doubtlessly provide the most comprehensive information regarding the gods and cults, but furthermore thousands of uninscribed monuments exist. There have been so many examples of inscribed materials recorded from different regions of Asia Minor to date, that it is almost impossible to make any general assessment and comment on the religious history of the country in antiquity without firstly evaluating these inscriptions thoroughly in their entirety and in respect to their regions; see Schuler 2002, 458.

${ }^{12}$ Paz de Hoz 1999, 15 no. 19; 68-69; 195 no. 19.1.

${ }^{13}$ Herrmann - Polatkan, 1961, 125-126 no. 15 Pl. IV. For the further editions of the inscriptions, see here cat. no. 6 .

${ }^{14}$ Malay 1999, 47-48 no. 36 fig. 36.

${ }^{15}$ Greenewalt and Payne briefly refer to the Hecate cult in Sardis and throughout Lydia in a book published in 1978 (Ritual Dinners in Early Historic Sardis) which mentions the monuments that were known un- 
cluded those monuments which very probably come from Lydia. The catalogue is divided into five parts. In the first part, the monuments in the museum, whose find-spots are known, are listed. The second part of the catalogue comprises those monuments whose find-spots are not given in the inventory or are unknown. The third part is devoted to monuments outside the museum. Coins with the depiction of Hecate minted by Lydian cities are presented in the fourth part. The fifth and final part deals with two monuments, which may possibly have a connection to Hecate which, however, cannot be regarded as fully proved.

Hecate is a multi-dimensional goddess whose existence is first attested in the $7^{\text {th }}$ c. B.C. by Hesiod, the first documentary evidence dates from the $5^{\text {th }}$ c. B.C. ${ }^{16}$ and she ${ }^{17}$ was commonly associated with ghosts, spirits and witches in later centuries. Those who wanted to protect themselves from Hecate and her attendants mostly placed a triple-bodied Hecate statuette $\left(\right.$ Hecateion $\left.^{18}\right)$ at the crossroads or in front of their homes or near the doorways. ${ }^{19}$ That Hecate was worshipped over a large area

til then; see Greenewalt - Payne 1978, 44 fn. 15. In this footnote, they pointed to the existence of some monuments in the Manisa Museum with their inventory numbers, which I introduced in this paper for the first time. However, a relief (?) relating to Hecate (from Sidas/Inncikler), whose inventory number is given as 151, is not presented in my catalogue, because I could not find it in the museum.

${ }^{16}$ Hesiodos mentions Hecate in his Theogonia, see Hes. Theog., 411-452 (West 1966). For the earliest documents, see the compilations of Nilsson 1906, 394-395; Kraus 1960, 58-64; Sarian, LIMC VI, 985; Johnston 1998, 268; Lautwein 2009, 64-80.

${ }^{17}$ As the cult of Hecate is intensively attested also beyond Asia Minor, especially in mainland Greece and in its environments, there are quite a few studies of the cult in those areas. Even though the studies on the cult of Hecate have increased in recent years owing to the new material obtained from surveys and excavations, a general publication relating to the situation and the spread of the cult in the ancient world is still a desideratum. Some of the main studies concerning the goddess accomplished in the last 20-25 years are cited in Akyürek Şahin 2011, 238 fn. 10. For some important general studies in recent years see ibid., 238, fn. 9. For general studies providing useful information about Hecate and her cult see Steuding 1884-1890; Roscher 18861890; Nilsson 1906, 394-400; Heckenbach 1912; Nilsson 1948, 71-73; Nilsson 1955, 722-725; Stiegler 1967; Berg 1974; Roloff 1994; Kehl 1988; Johnston 1998.

${ }^{18}$ The words Hecateion or Hecataion means "triple statue or statuette of Hecate" and at the same time refer to a small sanctuary in honour of her; see Eckstein 1965, 27 fn. 1 and Akyürek Şahin 2011, 237 fn. 1. In this paper, I have preferred to use 'Hecateion'.

${ }^{19}$ On this issue, see Nilsson 1906, 395-396. It is documented that Hecate statuettes were also placed as apotropaic within the wall niches of private houses to protect the houses and their inhabitants; see Filges 1999, 426 fn. 232 (on Delos island). Not much is known about the cult of Hecate, whereas we possess a wealth of information about the goddess herself (Brahms 1994, 177). The sizes of Hecateia led scholars to think that they functioned either as votive offerings or as cult statues (Kraus 1960,155). The large sized ones, being few in number, are considered as cult statues. The small sized ones must have functioned as both for votive offerings and for use in households, near the doorsteps or at the crossroads to repel evil, as mentioned above. Tiny ivory or bronze Hecateion figures, which were used as apotropaic objects and which were worn around the neck, have been discovered (Brahms 1994, 179.) For the functions of Hecateia and the considerations as to where they could be set up, see Akyürek Şahin 2011, 240-241. D. Willers $(1990,302)$ asserted that all the extant Hecateia are statuettes and that they are monuments pertaining to the sphere of private piety of individuals ("Alle erhaltene Hekateia haben Statuettengrösse, gehören also in den Bereich der privaten Frömmigkeit und waren kaum öffentliche Denkmäler"). Although the idea of Willers is not without basis, it is now well known that all the extant Hecateia do not always take the form of statuettes. 
around the Mediterranean was already recorded in an earlier time and T. Kraus compiled all the relevant documents in $1960 ;{ }^{20}$ since then many further votive offerings to Hecate have been published, together with studies concerning her cult. ${ }^{21} \mathrm{~A}$ large number of unpublished material relating to her cult can, however, still be found in Turkish museums. ${ }^{22}$ Uninscribed monuments in museum depots have not attracted scholarly interest for years, whereas cultic inscriptions were mostly included in the corpora. Considering both the inscribed and uninscribed documents as a whole, it becomes clear that the cult of Hecate was widespread in Asia Minor primarily in Caria and then in Phrygia. Lydia, bordering Caria and Phrygia, was deeply influenced by the culture and cults of its neighbours. Lydia's areas bordering Caria were influenced by the Carians, while the areas bordering Phrygia are in a similar manner under the influence of Phrygia. The documents collected for this paper suggest that the cult of Hecate does not exist throughout Lydia, but rather in the eastern area, which in academic publications is generally termed 'North-eastern Lydia'. ${ }^{23}$

In one of his papers, ${ }^{24} \mathrm{Chr}$. Naour in 1981 explains the existence of the cult of Hecate in 'North-eastern Lydia' (to the south of Mysia Abbaitis) by the fact that the Phrygian region had a strong influence upon that region, which is indeed the case; ${ }^{25}$ it is now well established that Phrygia had a deep cultural influence upon north-eastern Lydia. ${ }^{26}$ As the monuments brought together in this pa-

${ }^{20}$ See in general Kraus 1960.

${ }^{21}$ See the publication list given above fn. 17.

${ }^{22}$ These monuments are being collected in a corpus by me and will be commented one by one in this corpus, cf. fn. 1.

${ }^{23}$ The eastern area of the east of Lydian Region is named as 'North-eastern Lydia', 'Katakekaumene' or 'Maionia' in various publications. The use of 'North-eastern Lydia' (= Nordostlydien), which was firstly employed by P. Herrmann, has now become common in scientific circles, see Lochman 2003, 204 fn. 27. However, Chr. Naour stated in a series of publications based on his surveys and epigraphical studies that this area in fact belongs to Mysia Abbaïtis and forms the south of this region, and that it was actually not a part of Lydia as was previously alleged; see Naour 1981 and Naour 1983. For other relevant papers of the author, see Lochman 2003, $30 \mathrm{fn}$. 31. But, as T. Lochmann states, the practise of terming the region incorrectly as northeastern Lydia still continues, Lochman, ibid., $204 \mathrm{fn}$. 28. Lochman also states that P. Herrmann (Herrmann Varinlioğlu 1984, 1 fn. 1) did not come to definite decision about using this term (to the south of Mysia Abbaitis) even after Naour's articles, see Lochman 2003, $204 \mathrm{fn}$. 28. Although I agree with the observations of Chr. Naour and the critisim of T. Lochmann, I consciously prefer the term 'northeastern Lydia' instead of 'south of Mysia Abbaïts' in order not to confuse the readers, both because I deal with the Lydian Region in this article and also because the term 'south of Mysia Abbaïtis' has not become widespread in academic publications. For the problem, especially for the wide distribution of Mysian settlements in Lydia cf. Nollé 2010, 71-126, esp. 77-81.

${ }^{24}$ Naour 1981, 20 fn. 37. T. Lochman also agrees with Naour, see. Lochman 2003, 198, fn. 16.

${ }^{25}$ A detailed study on the Hecate cult in Phrygia is still missing and I intend to prepare such a study. On this issue, see Lochman 1990,1, 457-458 and Lochman 2003, 90-91; 205; 264; 285. The iconographic appearance in Asia Minor of Hecate, whose cult is also widespread in Phrygia, is explained by Lochman by suggesting that her cult in Greece influenced and spread into Asia Minor; see Lochman 1990,1, 458 and Lochman 2003, 205 fn. 39

${ }^{26}$ Naour 1981, 16, 20, 24-27, 43; Naour 1983, 111, 126, 129-132, 139; Lochman 2003, 204 fn. 29. See Lochman's remarks on this issue: 'Lydia is a strongly Hellenized area and is not under the influence of Phrygia. However, a much different cultural situation appears in mountainous Mysia Abbaïtis, which is situated be- 
per indicate, Hecate is scarcely documented in the western areas of Lydia (only in Thyateira and some vague traces in Sardis), while there is an intense record of Hecate in the eastern areas, which in my opinion can certainly be related to this Phrygian influence. It seems clear that Hecate was not much worshipped in the Hellenized western part of Lydia.

So, to the findspots of the monuments treated in this paper, including the coins (largely preserved in the Manisa Museum), whose provenances are certainly known: Philadelphia: cat. no. 1-3 and the coins; Maionia: cat. no. 4-6 and maybe cat. no. 15 and the coins; Satala: cat. no. 7; Thyateira: cat. no. 8; Kollyda: cat. no. 16 and maybe cat. no. 17. The monuments of unknown provenances (cat. no. 912 and no. 18) were most probably found within the above-mentioned areas (see the map below for these areas). The ones numbered 13 and 14 are irrelevant to the cult of Hecate in Lydia since they belong stylistically to the Phrygian region. So, apart from the coins, the number of monuments found in Lydia and evaluated in this paper is 16. Information concerning their find-spots is given below.

Philadelphia: In the catalogue, there are a large relief block and two Hecateia certainly found in Philadelphia (Alaşehir). The city minted coins on which Hecate is thought to be depicted (see the section 'Coins'). It is clear that the goddess had a cult in Philadelphia; yet we do not have any epigraphic evidence from the city, whereas coins, reliefs and statuettes of Hecate have been found. ${ }^{27}$ We can therefore assume a Hecate sanctuary in the city or within its territory, despite the scarcity of evidence.

Maionia: ${ }^{28}$ In the catalogue, there are a small stele with relief, a large stele with relief and one inscription (cat. no. 6) in Maionia (Gökçeören village). Another stele with relief was possibly found there (cat. no. 15). Coins, which are thought to be related to Hecate, are minted by the city. Herrmann and Polatkan underline that on the basis of the this evidence we must take it for granted that the cult of Hecate existed in Maionia $^{29}$, so that we have to reckon with a sanctuary of hers in the city of Maionia.

Satala: The stele (cat. no. 7), found in this settlement and depicting the one-bodied goddess is not secure evidence for a cult of Hecate at Satala.

Thyateira: An inscribed altar found on the territory of the city is dedicated to Hecate, to the emperor Antoninus Pius and the empress Faustina (cat. no. 8). It is evidence for a more or less locally important Hecate sanctuary in Thyateira's countryside, but we do not know whether there existed an important cult of the goddess in the city of Thyateira itself. Till now no coins minted by Thyateira indicate the importance of Hecate for the city state of Thyateira.

tween these both cultural landscapes as a geographic buffer zone and has a relation to Phrygia rather than to Lydia in terms of its religious history and mentality'. As Lochman considers north-eastern Lydia as a part of Mysia Abbaitis, he does not refer to this detail again and uses the term 'Mysia Abbaitis' in general as in his above cited article. The cultural interaction he mentioned already includes the whole of Mysia Abbaitis.

${ }^{27}$ No inscription is recorded in the corpus of Petzl, TAM V 3.

${ }^{28}$ Sometimes the name of Maionia is applied to north-eastern Lydia, whereas Homer uses it for the whole Lydia. In this paper, "the city of Maionia" is meant.

${ }^{29}$ Herrmann - Polatkan 1961, 126 and here fn. 43. 
Sardis: In this catalogue it is demonstrated that the Hecateion which has allegedly been found in Sardis is actually of Phrygian origin (see cat. no. 14). Even if it was found in Sardis, it does not indicate a Lydian cult of Hecate, because it is not a Lydian monument. It may show that foreigners from Phrygia continued their traditional cults in the Lydian capital. Furthermore, ritual food deposits discovered among the pottery vessels in Sardis and consisting of puppies inclined scholars to think that these animals might well have been sacrificed to Hermes or Hecate (see footnote 34). Yet, even these archaeological findings are not unambiguous evidence for a cult of Hecate in Sardis.

Kollyda: In quite early publications a small Hecateion (cat. no. 16) is mentioned as well as an inscribed votive stele with a Hecateion relief on it (cat. no. 17). The Hecateion listed under cat. no. 16, about which we do not have much published information, may be identical with one of the monuments of unknown provenance given in this catalogue. The inscription of the votive stele (cat. no. 17) is fragmentary. It is possible that it was dedicated to Hecate because of the Hecateion relief it carries. Since the origins of both objects are doubtful, they do not provide secure evidence for a Hecate cult in Kollyda.

Sidas (İcikler): Greenewalt and Payne (1978, 44 fn. 15) make mention of a relief housed in the museum of Manisa (inv. no. 151), which has to do with Hecate, but I could not find it in the museum, cf. fn. 15.

All the Hecate monuments examined in this paper are from the Roman Imperial Period. Only the inscription documented under cat. no. 17 is dated to the early Imperial Age., with dating by the Sullan Era to the years of 15-16 A.D. Apart from this monument, which is moreover not certainly related to Hecate, it is possible to date all of our monuments to the $2^{\text {nd }}$ century A.D. There are no Hecate monuments in this area which can be securely dated to the Hellenistic or earlier periods apart from some vague traces in Sardis. So the cult, which became widespread in North-eastern Lydia under Phrygian influence, may be conceived as a phenomenon of the Roman Imperial Age. Based on the documents and information compiled in this paper, we can conclude that the monuments regarding Hecate are not many in number and that geographically they are mainly documented in the east of Lydia. As emphasized above, this phenomenon must be explained by the influences of Phrygian cult and culture on that area. Since in the Hellenized parts of western Lydia the cult of Hecate is barely attested, we tend to assume that the Hecate worshipped much more intensively in the eastern parts, is the Hellenized version of a goddess of Anatolian origin, as was the case in Phrygia. 


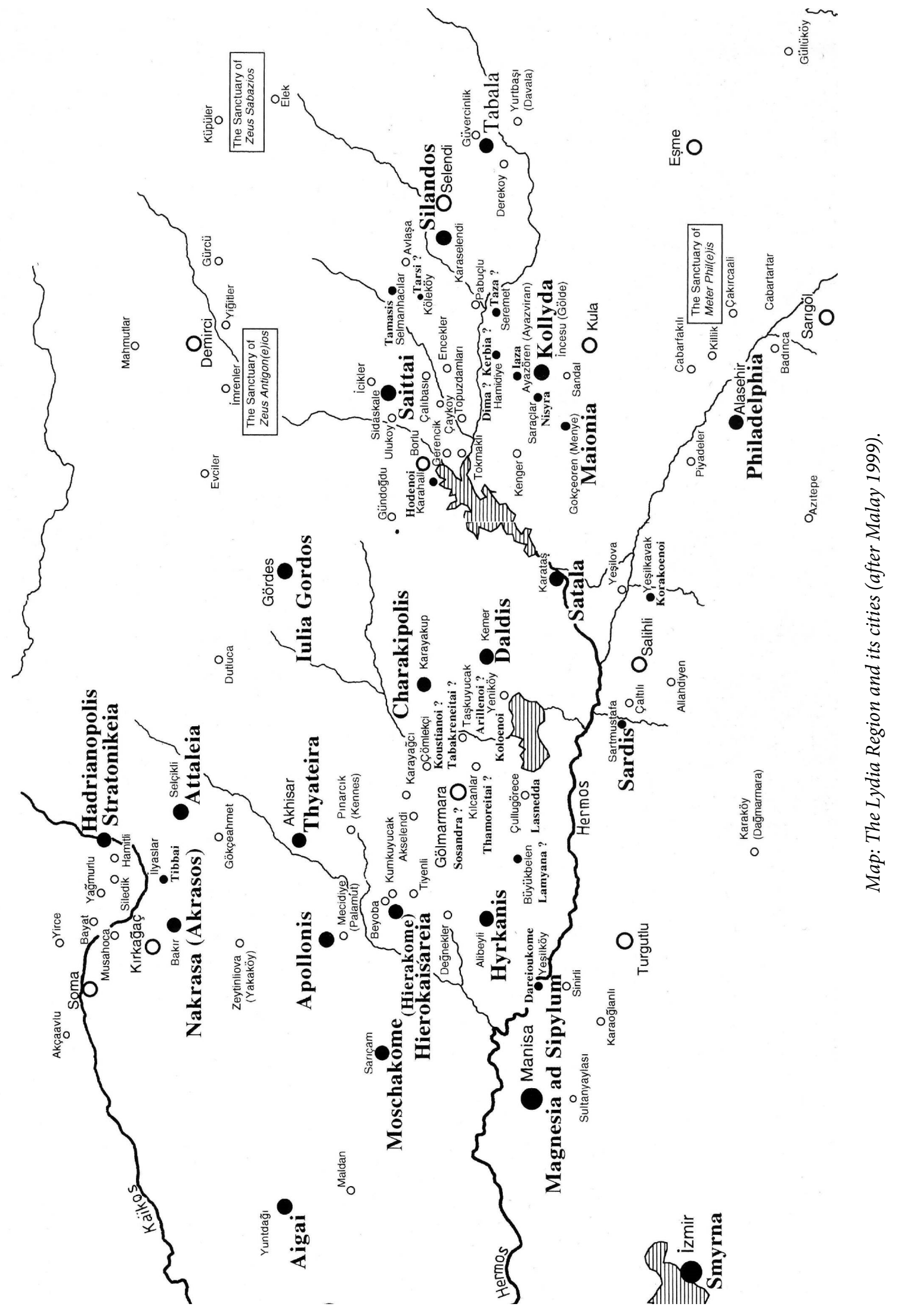




\section{The catalogue of Monuments concerning the Cult of Hecate in Lydia ${ }^{30}$}

\section{Monuments in the Manisa Museum with known provenances}

\section{Philadelpheia}

\section{Block from frieze (Figs. 1 a-f)}

Limestone; Inv. No.: 6449; Find-spot: Philadelpheia (Alaşehir)/Manisa (this block was found during canalisation work in front of a shop on Filadelfiya Street, no. 130a in Alaşehir in 1985 and transferred to the museum by the Alaşehir excavation team). H.: $136 \mathrm{~cm}$; L.: (upper) $120 \mathrm{~cm}$; (lower) 122 cm; D.: 25-35 cm.

Ed.: Meriç 1987, 262 and 27 fig. 9 (only stating that the monument was discovered and providing a photo). The photo is also given in Akyürek Şahin 2006, 65 fig. 9 and Durugönül et al. 2015, 140-141 no. 79. This monument is not included in the inscription corpus of Philadelphia as it does not carry an inscription. But G. Petzl, the editor of the corpus, indicates that he is aware of the monument by mentioning the publication of R. Meriç in the index of his work, see Petzl, TAM V 3, p. 305 (Index Götter...) s. v.'Екátๆ.

It is impossible to say whether the monument was found in situ or not, since it was not discovered in a systematic excavation. The fact that this frieze block was presumably employed in a major building, but was found during canalisation work in an unknown structure may imply that it did not stand in situ. The hole, which in my opinion was cut at a later period, confirms this hypothesis. This relief block may have been built into an orthostat wall.

While the block is broken left and above, it is nonetheless largely complete. In the lower part there is a space (figs. 1a and e) with two thin and distinct mouldings functioning as a baseline for the reliefs. The moulding profiles are partly broken and the space between them is smooth. There is no ornament or decoration on this part. On its upper part, the level of the block is lowered and in this space figures in high relief are depicted (figs. la and b). In the middle of the upper moulding of the base there is a hole (figs. 1a and e). It does not make sense to consider that this was already cut in antiquity. There are no traces to think that the block was employed in a water-related construction. It seems more reasonable to claim that the hole was made in order to revise it for a fountain. Because the upper part is broken, the exact height of the block is unknown. However, the height of the relief figures gives us an idea. The block is bordered by a thin and smooth moulding profile on the right, indicating that the relief was not continued to the right. Although the left side of the block is to a large extent broken, the high and broken protrusion on the left of the carving of the dog (fig. 1f) indicates that the moulding profile on the right also exists on the left. Therefore, it is a relief block framed and bordered all around by a thin moulding profile. The high reliefs show two main figures. On the left side there is a triadic figure of Hecate (fig. 1c), on the right a figure of Men (fig. 1d). Hecate (fig. 1c) is depicted as a full frontal figure with two three-quarter figures on her right

\footnotetext{
${ }^{30}$ In this paper, all the photographs employed in this catalogue nos. 1-13 belong to the author.
} 
and left side. All three figures spread their arms wide and hold short torches in both hands. ${ }^{31}$ There are six torches on the relief in total.

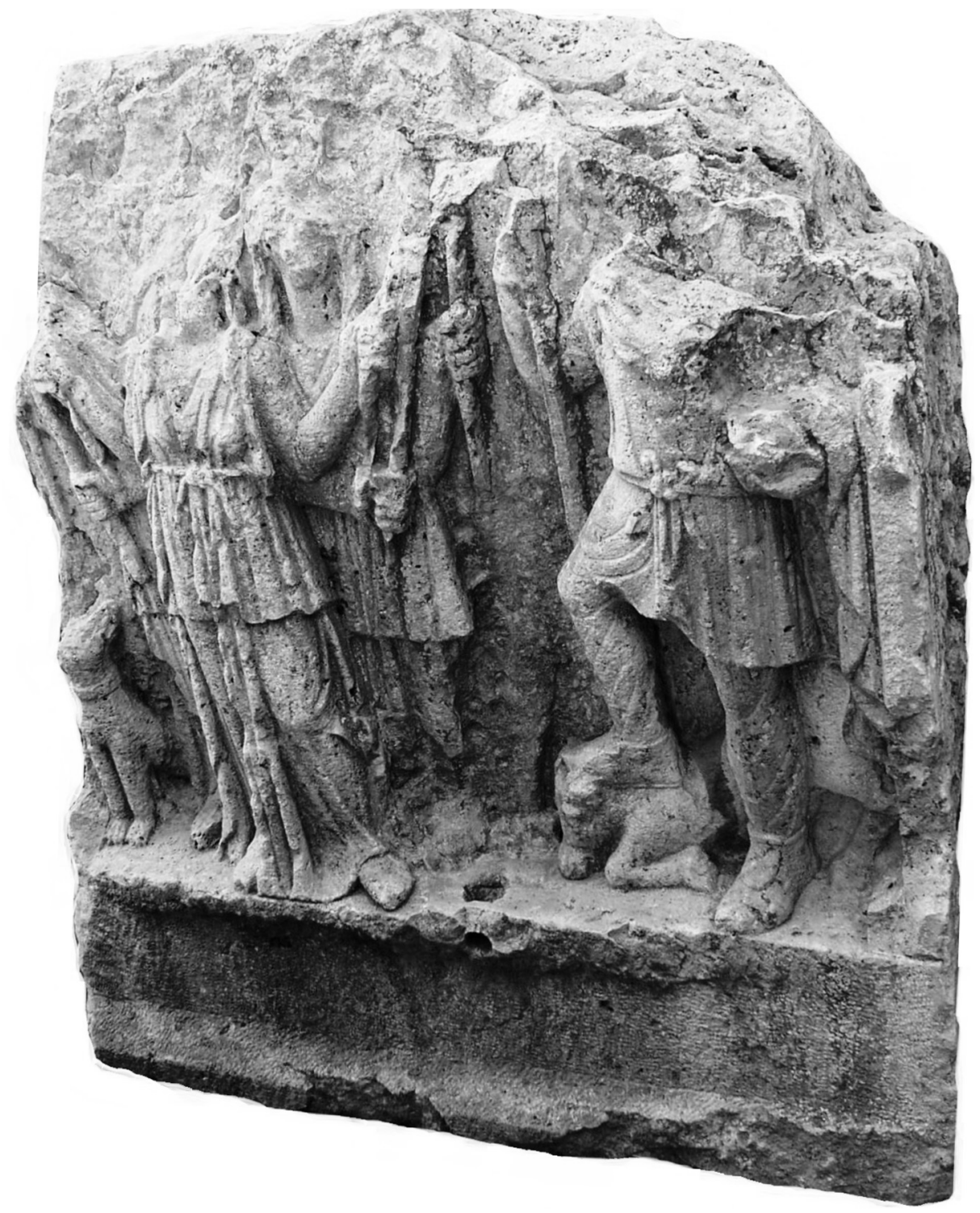

Fig. $1 a$

The frontal figure is resting on her right foot; her left foot extends to the left and her leg is lightly bent at the knee. Her feet appear beneath the hem of her dress. Only one foot of the side-figures can be seen. All three figures wear peploi $i^{32}$ and the dress of the figure on the front side is tied with a so-

\footnotetext{
${ }^{31}$ The most significant symbol of the goddess is the torch. For her torches, cf. Werth 2006, 153-165. Werth noticed that in the iconography of Hecate the depiction of the short torches was employed mostly in the Roman Imperial Period, see ibid. 153 and fn. 503.

${ }^{32}$ There are various debates on the dress of Hecateia, see for example Willers 1990, 302 (chiton); Eckstein 1965, 29. Eckstein points out that it is difficult to determine, whether the dress of Hecate is a peplos or a chiton, but he himself favours a chiton, whereas Werth (2006, 51, fn 161) asserts that the dress of Hecate is a peplos, not a chiton. There are indeed many examples in the sources which show this confusion of ideas. For the dress of Hecate in general, see Werth 2006, 109-112 and on the peplos see ibid. 114-116.
} 
called Heracles knot (see below, on the figure of Men) below the chest. The goddesses' heads are badly damaged except for the right head. The right head is broken at the top; the facial features are lost. However, it appears that she wears a high polos $^{33}$ on her head and her long hair falls down to both of her shoulders. It is probable that the other heads, too, were crowned with a polos. On the right of the goddess is the depiction of a dog (fig. 1c and f).$^{34}$ The dog is in a sitting position and its face is shown looking up and turning its head to the goddess. Its facial features are lost, a leash ${ }^{35}$ around its neck is visible.

Men, depicted as of the same height as the goddess, puts his right foot on a lying bull, holds a staff (in some descriptions termed as thyrsos) in his right hand and leans towards it gently. His left hand is at waist height and he holds a pinecone whose top is damaged. The head of the god, possibly wearing a Phrygian hat, is missing. No traces of a crescent are visible, which would have been depicted behind his shoulders. The god wears short boots and long, loose trousers. He wears a chiton over his long-sleeved chiton and a chlamys (cloak) on it. The chlamys hangs down from his left arm. The belt of Men is tied with a Heracles knot, as it was the case for Hecate.

Some monuments, on which the god Men is depicted in such an iconography, are recorded from Lydia and Phrygia. The relief of a stele fragment found in Maionia shows the god in the same ico-

${ }^{33}$ The polos is an indispensable part of the iconography of Hecate; on this issue see in general Müller 1915.

${ }^{34} \mathrm{~A}$ dog occurs on the monuments listed under no. 1, 7 and 11 below. In the inscription of cat. no. 6 'a skylakaina' ( $\sigma \kappa v \lambda a ́ \kappa a ı v \alpha)$ is mentioned, describing in poetic language a 'female dog'. Like the torch, the dog is also one of the most significant and earliest attested symbols of Hecate. From the $4^{\text {th }}$ century B.C. onwards, the dog is attested on Hecate depictions and this animal is Hecate's companion till the end of the $3^{\text {rd }}$ century A.D.; see Werth 2006, 173. Werth found out that on representations until the $1^{\text {st }}$ century B.C Hecate was accompanied by only one dog; she notes that two or more dogs began to appear after $1^{\text {st }}$ century B.C. These dogs are mostly shown sitting, and only occasionally standing. A dog does not, however appear on all Hecateia. L. Robert, however, remarks when we find a one-bodied Hecate at least two torches and a dog are required to identify this goddess with reasonable certainty; see Hellenica X, 116 (cf. here cat. no. 7). Werth thinks that there are no traces in almost any of the depictions which confirm a closer relationship of the goddess with a dog. She thinks that the dog is just depicted near the goddess, mostly without relevant stories; see Werth, ibid., 174. Some sources from the Classical Period demonstrate that the dog was the sacred animal of Hecate, which trembled when the goddess appeared (epiphaneia). Dogs were even sacrificed to Hecate. For these sources and further details, see Werth, ibid., 174 fn. 632-635.

Many ritual dinner deposits were recovered in small pottery vessels in Sardis, most of which included the bones of young dogs. It is assumed that these dogs were slaughtered as a sacrifice for Hermes or Hecate; see Greenewalt - Payne 1978, 43 fn. 12 and p. 44-45; Crawford - Greenewalt 2010, 240-242. On the dog sacrifice, see Werth, ibid., $175 \mathrm{fn}$. 641-642. Apart from these, the dog is linked with the goddess in connection with practises of magic and spells. The sources from later periods show that the dog was a part of Hecate's flock, which wandered around during the night and consisted of spirits and dangerous creatures. Hecate was also accompanied by the dog in her underground activities. Even Hecate herself was considered as a male or female dog. As a result, the dog is the sacred animal, attendant and companion of the goddess. On Hecate and dogs see also in general, Orth 1913, 2577-2578; Scholz 1937, 40-43 (Hekate); Nilsson 1955, 724; Berger-Doer 1997, 545-549; Johnston 1998, 269; Zeleny 1999, 67-74; Brehm 2002, 28 fn. 19. For the depiction of dogs between the Hecate figures of a Hecateion, see Şahin - Taşlıalan 2010, 204-205 no. 26 and 238 fig. 41.

${ }^{35}$ Likewise, for a dog depiction with a leash around the neck near Hecate, see Kraus 1960, 177 no. A35; Werth 2006, 308-309 no. 37. 
nography; see Cook 1964, 731 fig. 540 and 642 fn. 4. He is very similar depicted in high relief on a stele discovered presumably in the area of Kütahya (Phrygia) and now housed in the British Museum; see Drexler 1894-1897, 2714 fig. 6 = Lane 1971, Men, pl. 45 no. 102 = Naour 1983, 115 fn. 33. But, on both of these reliefs, Men puts his left foot, not the right one as here, on a bull. For the iconography of Men in general, see Vollkommer 1992. The monuments on which the goddess Hecate is depicted together with Men are in particular found within the province of Kütahya in Phrygia. We see both gods standing side by side on two small stele fragments (inv. nos. 23 and 6537) which I shall shortly be publishing. In addition, two more depictions of both gods occur on a grave stele from Kütahya, preserved today in the Istanbul Archaeological Museum; see Pfuhl - Möbius 1979, 502-503 no. 2089 fig. 300. It is highly likely that people in antiquity must have established a connection between these two moon divinities.

The monument can be dated to the $2^{\text {nd }}$ century A.D., on the basis both of its stylistic features and of similarities with other precisely dated examples.

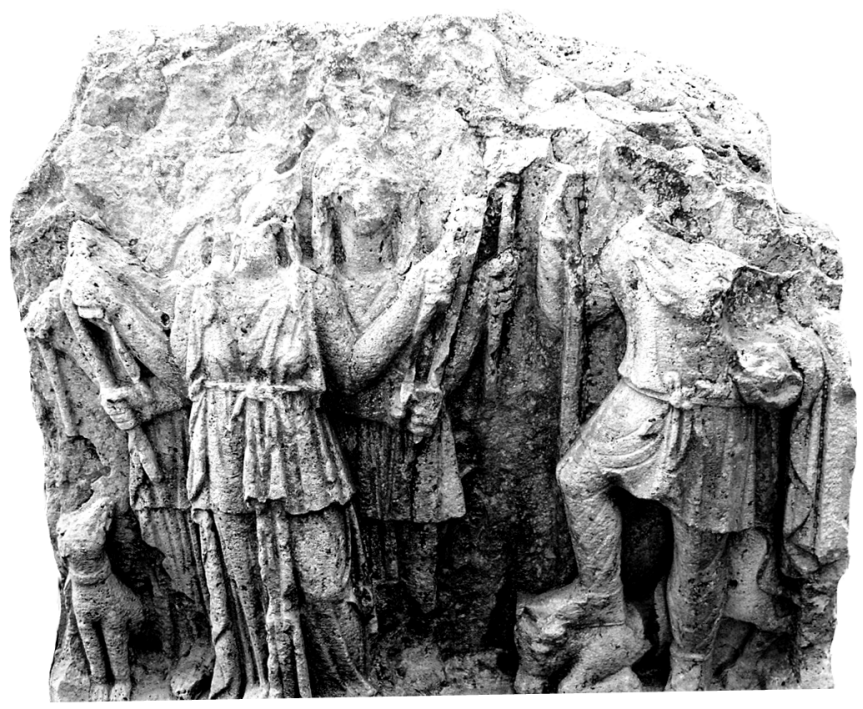

Fig. $1 b$

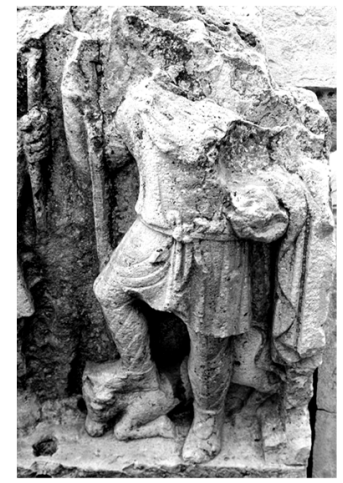

Fig. $1 d$

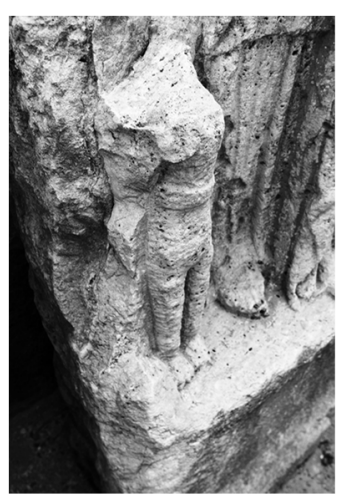

Fig. 1e

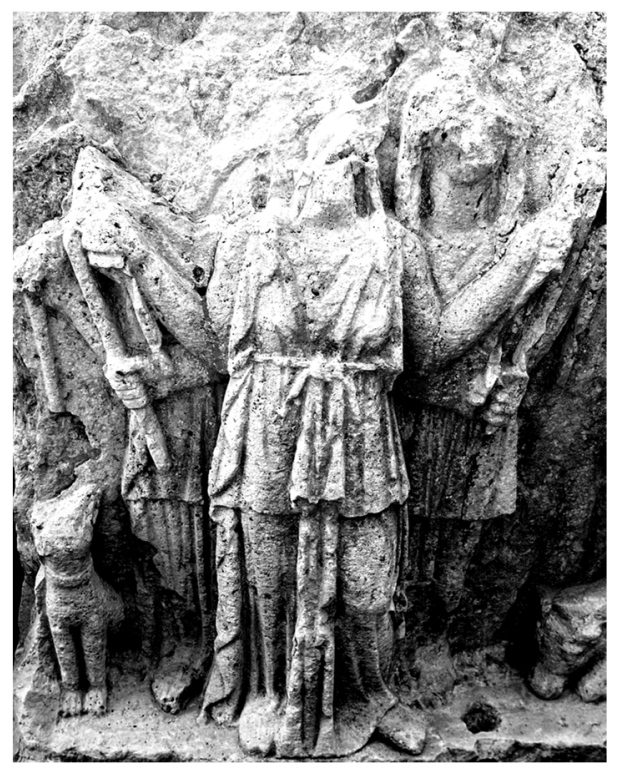

Fig. 1c

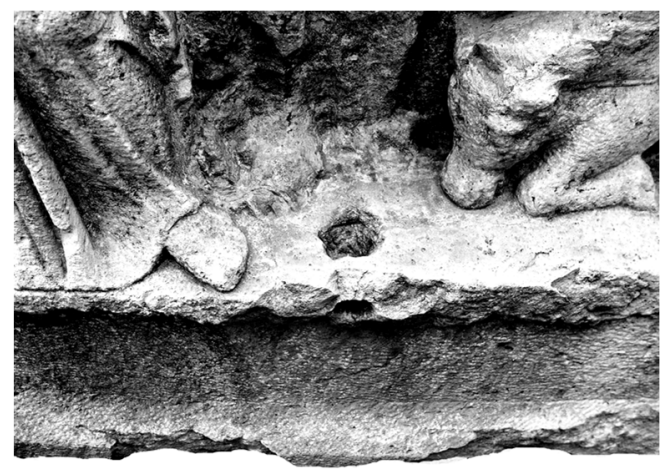

Fig. $1 f$ 


\section{Hecateion (Figs. 2 a-g)}

Gray marble ${ }^{36}$; Inv. No.: 373; Find-spot: Philadelphia (Alaşehir)/Manisa (donated to the museum; brought to the museum in 1946); H.: (complete) $39 \mathrm{~cm}$; (head) $9 \mathrm{~cm}$; L.: $14 \mathrm{~cm}$; (head) $9 \mathrm{~cm}$; D.: 12 $\mathrm{cm}$; (head) $8 \mathrm{~cm}$.

Ed.: Hanfmann - Ramage 1977, 172 no. 263 fig. 453; Greenewalt - Payne 1978, 44 fn. 15; Durugönül et al. 2015, 142 no. 80 .

In the case of this statuette, the goddess consists of three female figures standing back to back. This is very common for the iconography of Hecate. The head of the goddess was broken off, but has been restored. On many parts of this Hecateion there are visible breaks and damages. The three heads of the goddess apparently had a common polos, broken off and today missing. There are breaks and traces of abrasion of the faces and the hair. All the arms are broken away below the shoulders, so that the hands holding torches are missing. Also the dress is partly damaged.

The statuette has three arms instead of six. But six arms adjacent to each other must have originally been conceived, because the arms are disproportionally thick. All three figures are depicted as wearing peplos and having a dress tied with the belt below the breast. The smooth hair extending to the shoulder is parted in the centre. The monument is roughly worked and symmetrical.

Ramage argues that the monument should be dated to the $2^{\text {nd }}$ century A.D.

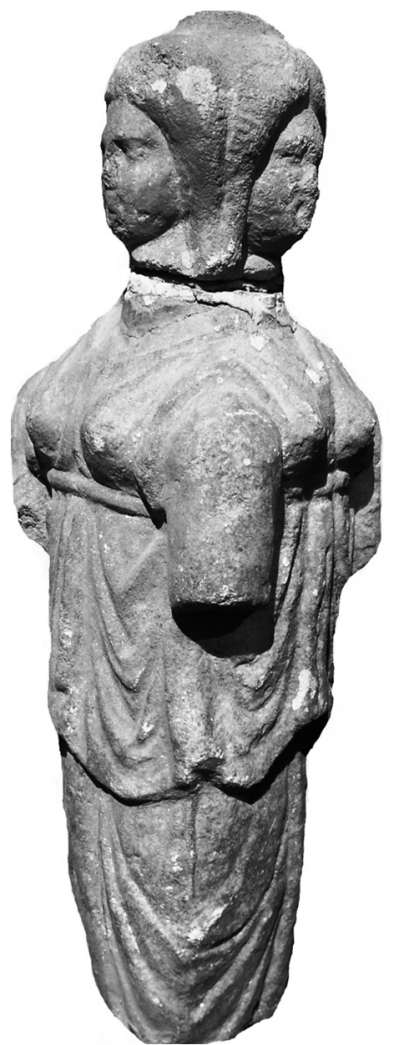

Fig. $2 a$

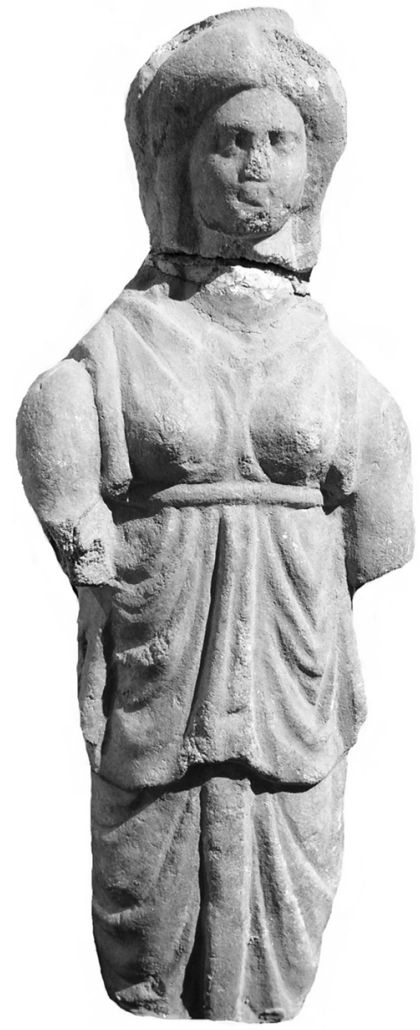

Fig $2 b$

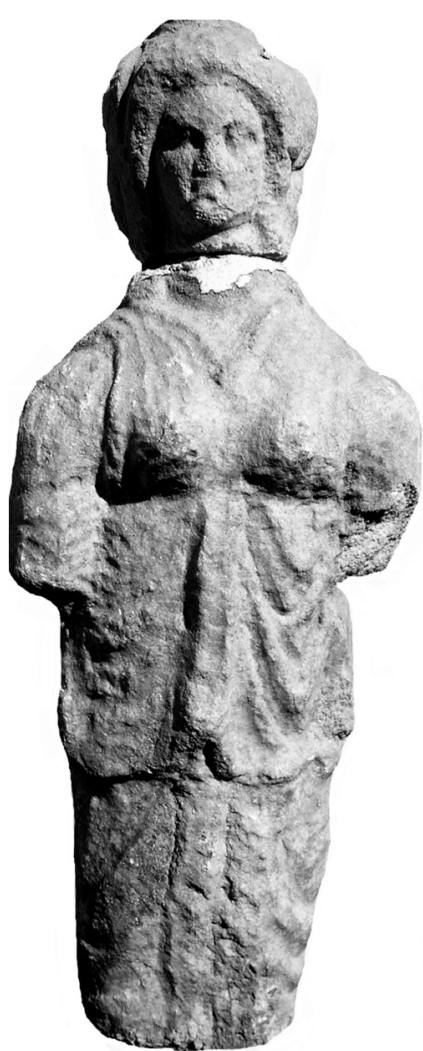

Fig. $2 c$

${ }^{36}$ In this catalogue, all the stone monuments are of marble except for no.1 (limestone). But it is known that Hecate monuments were also made of other materials, including bronze and ivory, see Werth 2006, 173, fn. 624 . 


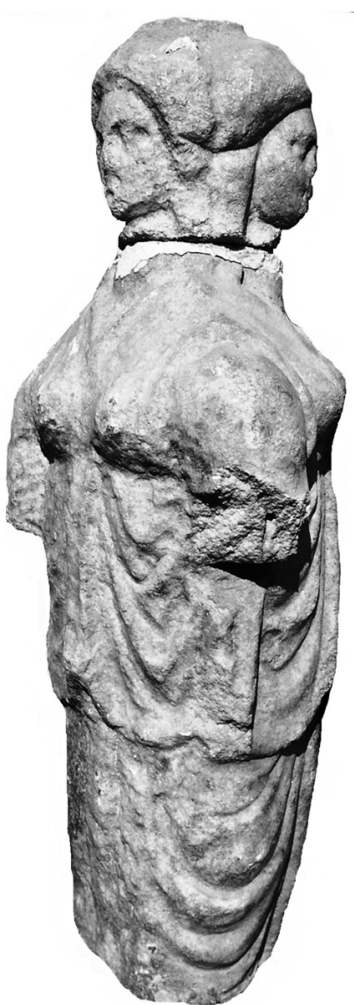

Fig. $2 d$

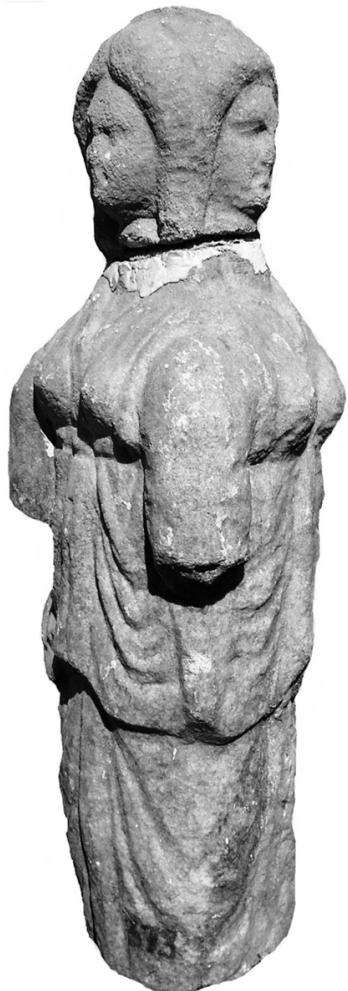

Fig. $2 e$

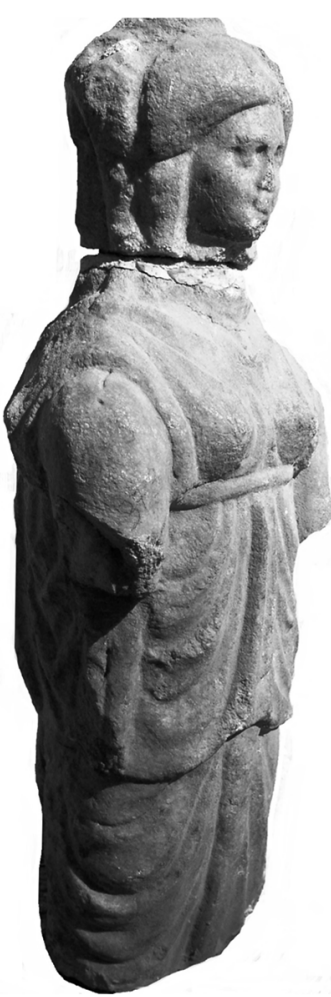

Fig. $2 f$

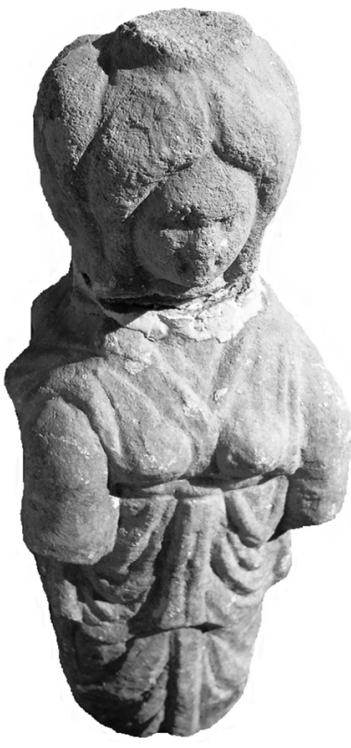

Fig. $2 g$

\section{Hecateion (Figs. 3 a-1)}

White marble; Inv. No.: 6629; Findspot: Philadelphia (Alaşehir)/Manisa (purchase); H.: $25 \mathrm{~cm}$; Diam.: (at the top) $12-13 \mathrm{~cm}$; (at the bottom) $15-16 \mathrm{~cm}$.

Ed.: Durugönül et al. 2015, 142-143 no. 81.

This Hecateion is partly broken above and below, damaged severely on its surface, but otherwise well preserved. It is of small size and is composed of three female figures, leaning their backs against a thick column. The central column is thicker than necessary and in this respect this Hecateion differs from conventional Hecate depictions. It has a rough and unpleasant appearence as it stands. The column is not entirely cylindrical and shows a slight inclination. It has a clumsy appearance due to the coarse long torch the goddess holds in her hand. The top of the column ends with a horizontal cut. Below there is an unsuccessfully worked low section, which is also lopsided and may have been intended as a base. The three female figures standing around the centre column are not all alike. All three figures hold a long torch touching the ground; each of them holds the torch with the right hand, while the left hand is grasping a piece of the dress. The flame, proving that they actually hold torches in their hands, is indicated by a slight widening of the torch shaft's upper part. Under the hem of the dress the feet are visible. The figures do not touch each other and between them there are spaces offering a view of the surface of the column. The position of the feet is incorrect, as the toes of the feet face each other.

All three figures wear sleeveless peploi and their arms are bare so far as can be seen. The belt below the breast makes the dress fall down in pleats to the legs; this part of the dress ends rather far above the knees. The bottom of the dress extends to the feet and a thick pleat runs between the legs. 


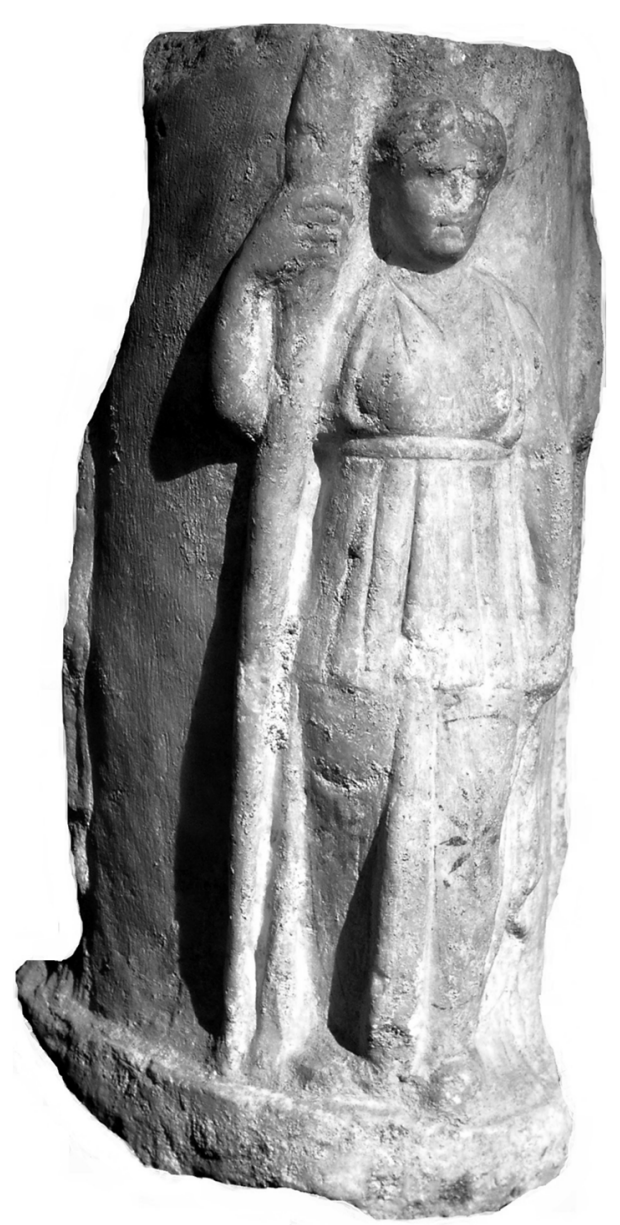

Fig. $3 a$

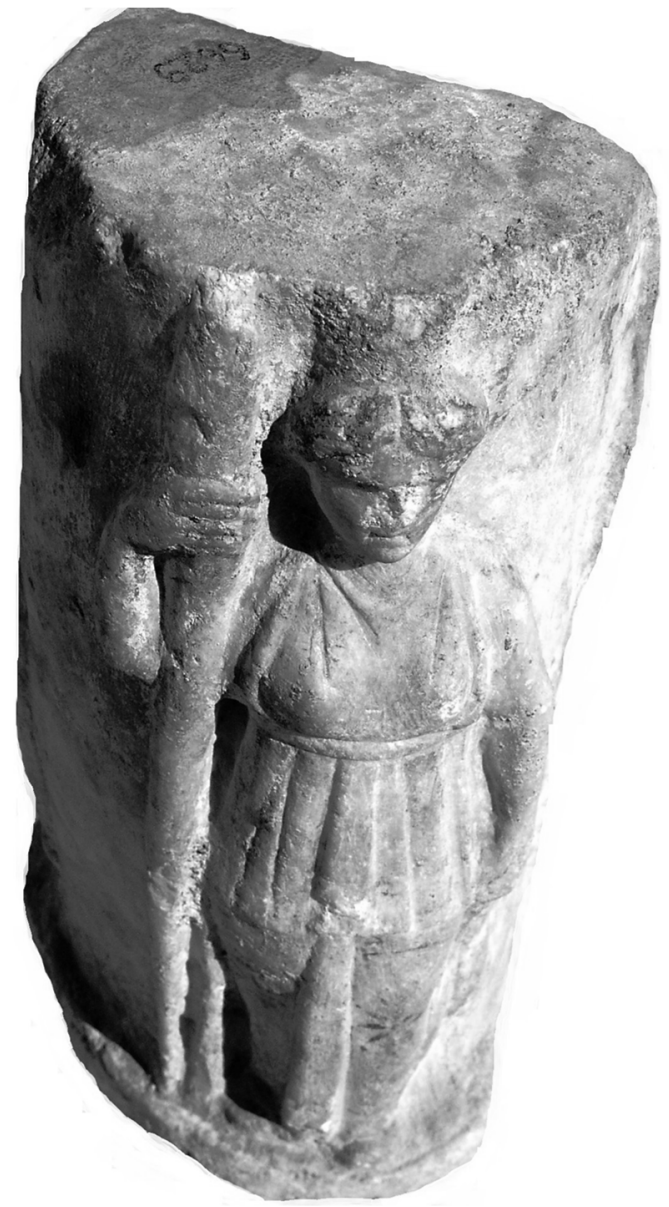

Fig. $3 b$

Some facial features of these figures are preserved, but the face of the third figure is broken. Thin facial lines are visible on the damaged faces. The hair is centrally parted above the forehead. Each of the three figures has a high polos on its head. It is understood that the Hecateion was painted, because there is a rosette shaped, thin-leafed, red-colored ornament resembling a star, which decorates the upper part of the dress of one of the figures (figs. 3a and 3c). The other two figures do not (today) carry this painted decoration, meaning that either it existed only on this figure or it has been lost from the others. Hecateia with remains of red color are known from the museums of Eskişehir (inv. no. A-94-92) and Antalya (inv. no. 2010/540, see Akyürek Şahin 2011, 240). Hecateia carrying long torches are already known from previous periods when compared to those having

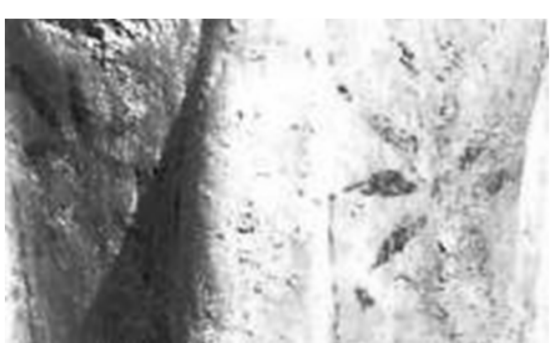

Fig. $3 c$ short torches, see Werth 2006, 153-154. That Hecate, a goddess of night, dark and underground, carries a torch indicates that she is active at night. The torch indicates that she is able to illuminate the darkness to provide light for the people. For detailed information on the torch of Hecate, see Werth, ibid., 153-165. This roughly worked Hecateion presumably dates to the $2^{\text {nd }}$ century A.D. 


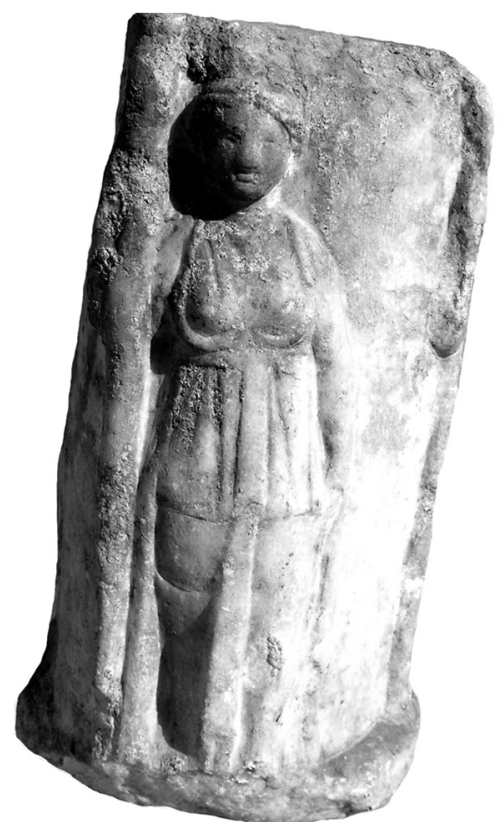

Fig. $3 d$

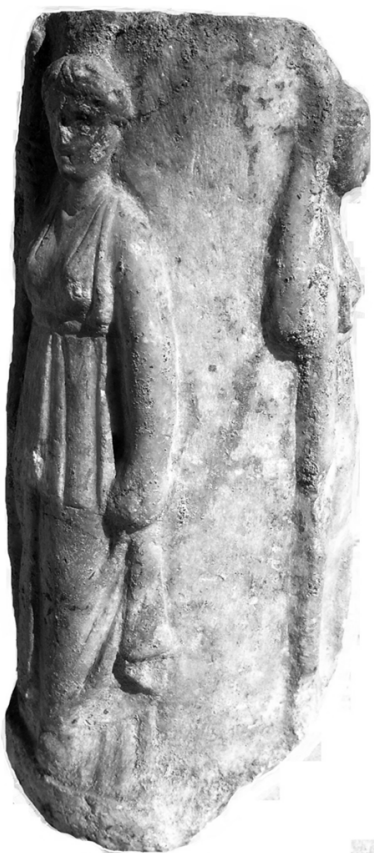

Fig. $3 g$

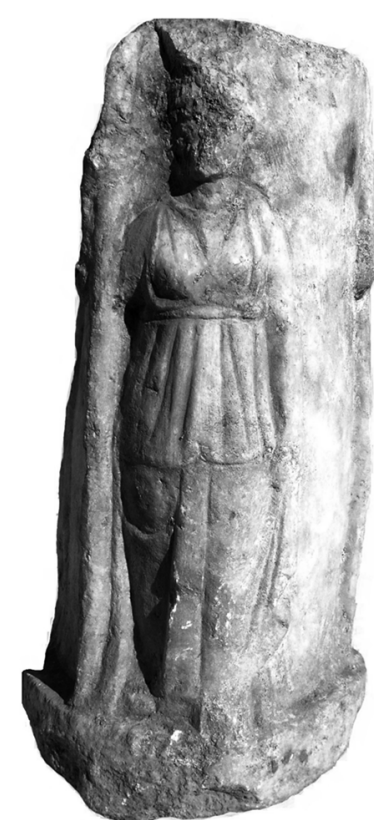

Fig. $3 e$

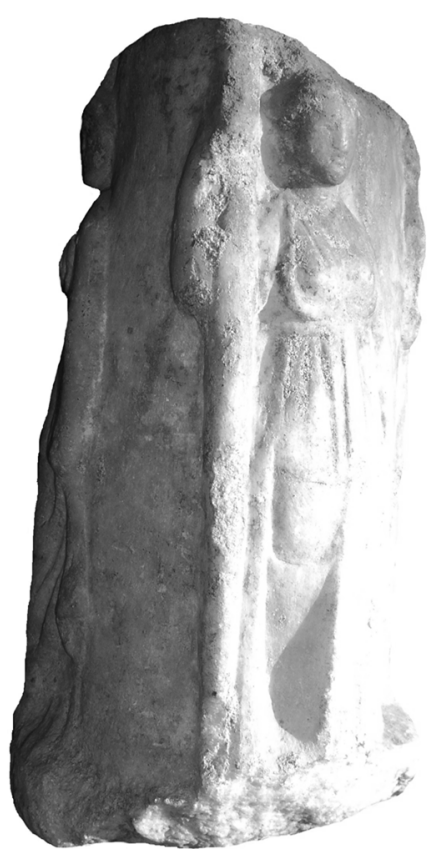

Fig. $3 h$

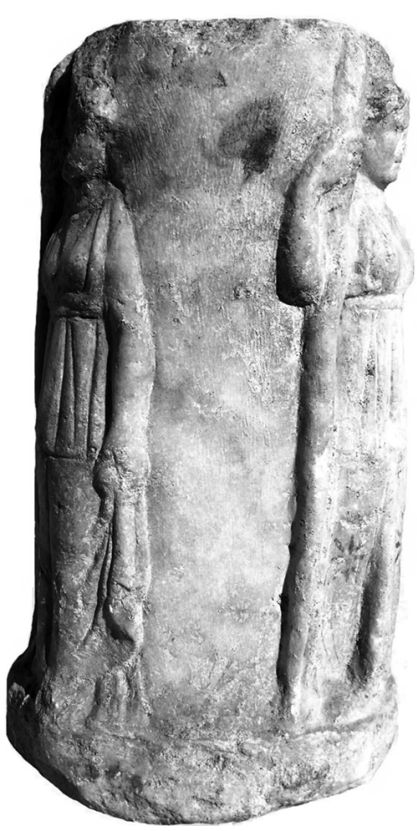

Fig. $3 f$

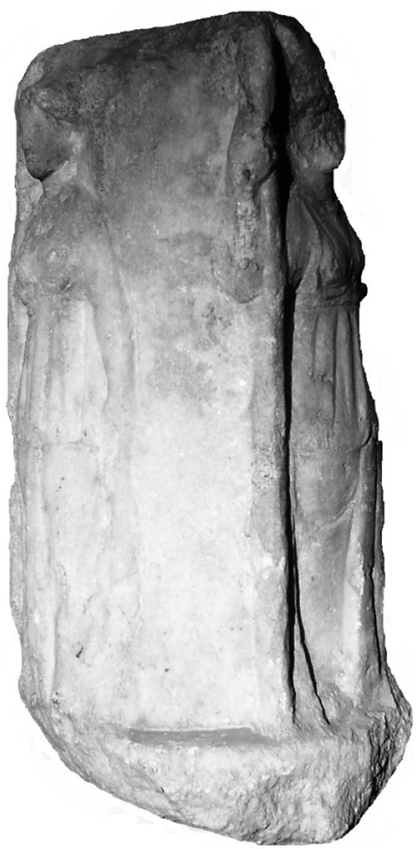

Fig. 31

\section{Maionia}

\section{Stele Fragment (Figs. 4 a-d)}

White marble; Inv. No.: 466 (old no: 1240). However, Greenewalt and Payne according to the report of the museum directorate assign this inventory number to a ceramic vessel,; see Greenewalt Payne 1978, 44 fn. 15); Find-spot: Maionia (Gökçeören village [former: Menye])/Kula /Manisa; H.: $24 \mathrm{~cm} ; L .: 33 \mathrm{~cm} ; D .: 9,5 \mathrm{~cm}$.

Ed.: Now s. Durugönül et al. 2015, 143-144 no. 82. A photo is provided by Akyürek Şahin 2006, 65 fig. 9. Herrmann - Polatkan (1961, 126), Greenewalt - Payne (1978, 44 fn. 15) and Paz de Hoz (1999, 68-69 fn. 440) notes its existence. 
Stele without pediment, carved from a small, thick and rough slab. It is broken at the bottom, therefore it is unknown if it had a base. The stele, framed by a rough border, shows the image of a Hecateion. The figures are broken below the waist. It is therefore unknown whether a dog was depicted at the feet of the goddess. Over the whole surface of the stele there are tiny breaks and damages. In particular, the face and the dress of the central figure as well as the hair of the other figures are worn.

The goddess is elegantly carved and the three figures stand back to back. The central figure stands in full frontal position, the others are carved in profile. The heads of the two lateral figures are slightly twisted to the right. All three figures hold a short flaming torch in their hands (see above cat. no. 1). The central figure, as well as the figure to her right have the torches in their left hands, whereas the other one holds it in her right hand. The torches and the frames are elegantly worked.

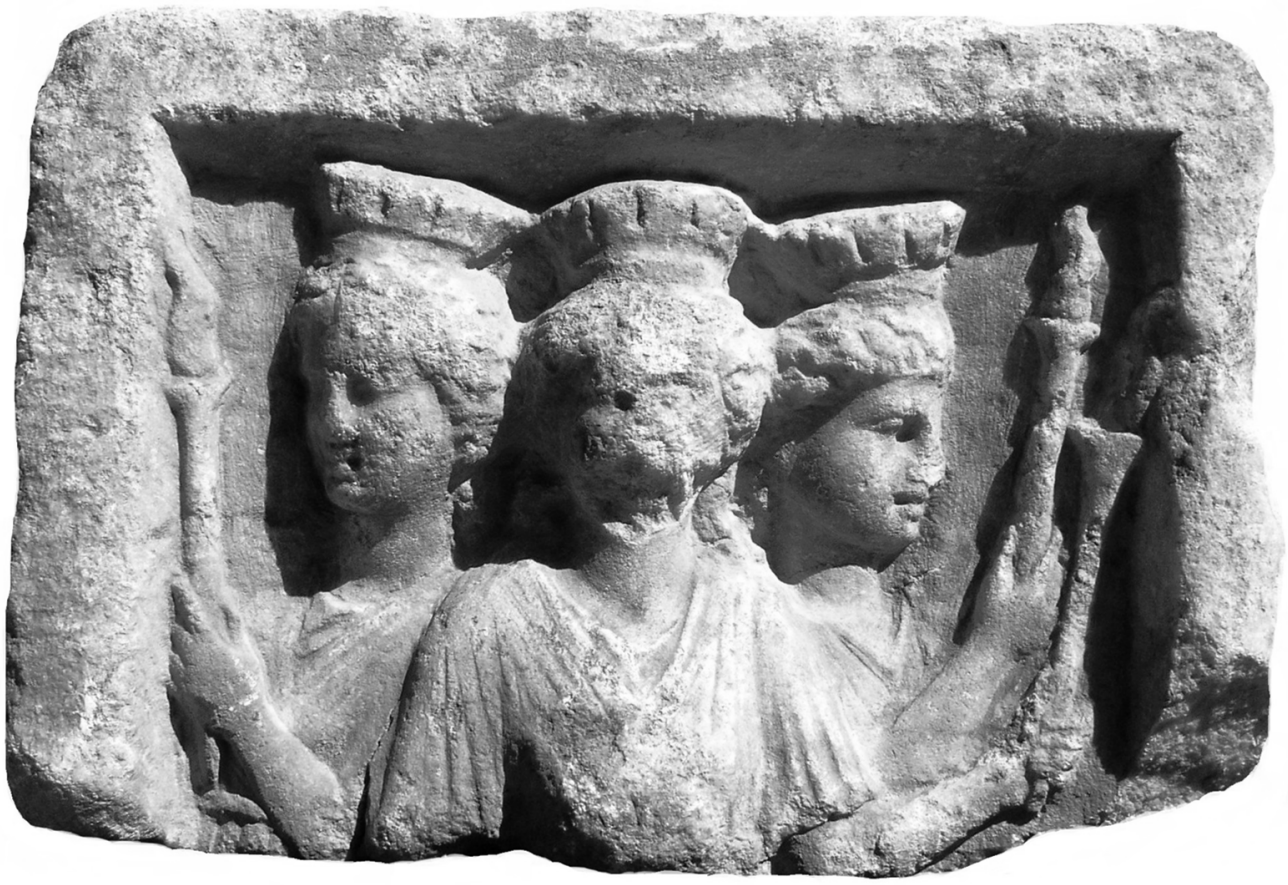

Fig. $4 a$

The goddess is depicted in a short-sleeved peplos. Her dress forms a loose and V-shaped fold at the neckline. The folds of the dress are thin and soft. On their heads the figures wear a low polos, whose upper part is shaped as a crown. These crowns resemble mural crowns (corona muralis) ${ }^{37}$ and touch each other slightly at the top. The cheeks of the figures are fat; their mouths are slightly opened. The wavy hair is rolled up at the nape of the neck. The figure on the left possibly wears a bracelet on her arm. Even though this depiction of Hecate is elegantly worked, the stele seems rough and lacking a detailed elaboration. Stylistically it may date to the $2^{\text {nd }}$ century A.D.

37 The mural crown does not form a part of the standard iconography of Hecate; yet it is found on some Hecateion depictions, where the goddess wears the crown, for example here cat. no. 14. The mural crown is a type originating in Mesopotamia and widely used in the Greek world from the Hellenistic Period onwards due to intercultural interactions; see Meyer 1996 and Meyer 2006, 111-112. On the mural crown see also Müller 1915, 46-51, as also for a discussion of the polos. 


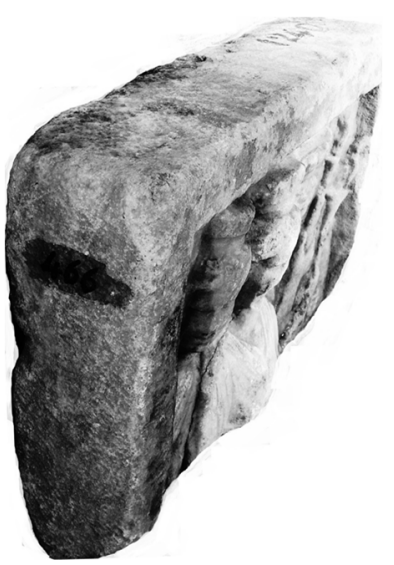

Fig. $4 b$

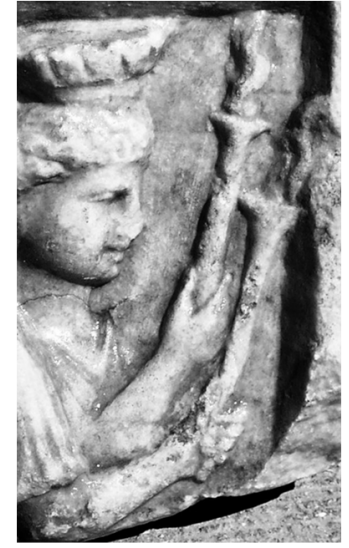

Fig. $4 c$

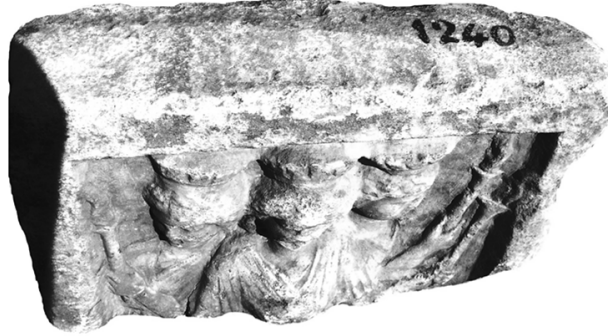

Fig. $4 d$

\section{Stele Fragment (Figs. 5 a-c)}

Marble; Inv. No.: 413 (old no: 1241). According to the report of the museum directorate Greenewalt and Payne assign this inventory number to a glass vessel, see 1978, 44 fn. 15); Find-spot: Maionia (Gökçeören village [former: Menye])/Kula/Manisa; H.: $52-53 \mathrm{~cm}$; height of Hecate depiction: 29 cm; L.: (top) $26 \mathrm{~cm}$; (bottom) $36 \mathrm{~cm}$; D.: 7-8 cm.

Ed.: Mitropoulou 1978, 48 no. 63 p. 96 fig. 79; Usman Anabolu 1987, 50 fig. 4 (giving the wrong inventory number); Usman Anabolu 1988, 127 fn. 55 (Author gives irrelevant information in this footnote and confuses the monuments. In addition, the inventory number is also incorrect ); Sarian, LIMC VI 1, 1003, no. 193; Werth 2006, 396 no. 223; Photo is provided byAkyürek Şahin 2006, 61 fig. 5. Herrmann - Polatkan (1961, 126), Greenewalt - Payne (1978, 44 fn. 15) and Paz de Hoz (1999, 68-69 fn. 440) mention it. Durugönül et al. 2015, 144-145 no. 83.

The stele is carved from a rough marble piece whose front surface was smoothed (lateral view: fig. 5a). It is broken all round. It is decorated with a depiction of Hecate in low-relief. It cannot be esti-

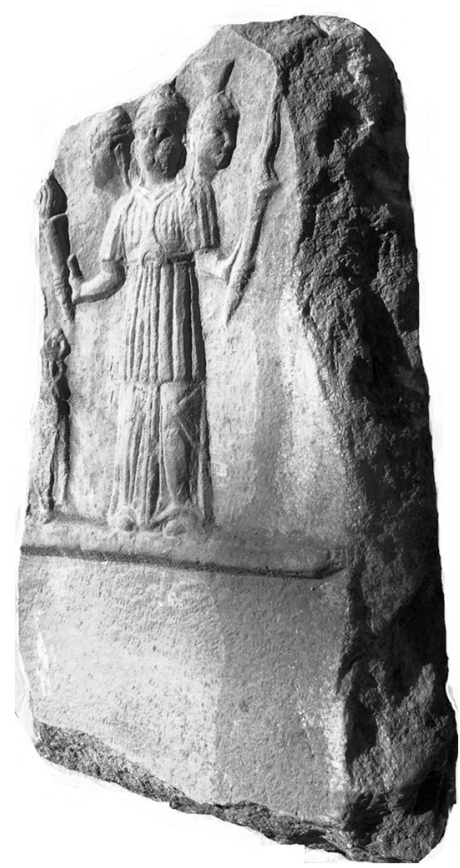

Fig. $5 a$

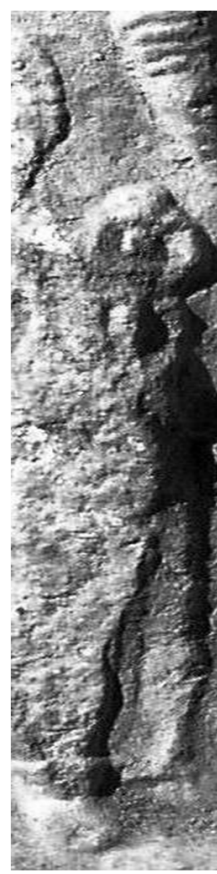

Fig. $5 b$ mated how far it extended to the top and the sides. The lower part of the stele is shaped as a pretty high base. At the top and bottom it is turned a little to the outside so that a slightly concave field results. This part is smoothed and polished and does not show either a relief or an inscription. A thin moulding profile separates it from the picture zone. Above the moulding profile there is a depiction of a Hekataion; to the right are traces of a smaller figure, which is severely damaged and broken. Only one body of the three-headed goddess is depicted, so that a further heads sit on the right and left shoulder of the facing figure. We may assume that the artist tried to depict three women figures standing back to back, but his attempt was not successful. The centre figure holds a short torch in each hand, whose flames are somewhat high (see above no. 1). The other figures do not have torches. 
The goddess wears a short-sleeved peplos and her dress is richly pleated by lines running parallel to each other. The legs, which are visible under the dress, are quite clumsy. Werth states that the goddess wears a peplos over a chiton, see Werth 2006, 396 no. 223. The feet end outside the fall of the dress. The peplos is tied with a thick belt below the chest. An object, hung from the neck, which appears to fall down to the waist, stands out in relief on the chest of the goddess. At the end of this necklace-shaped object is a depiction of a crescent that is oriented downwards and has downward pointing tips (fig. 5c). The crescent is placed right in the middle of the belt of the peplos. The facial features of the heads are damaged. It appears that they both wear a conical polos; only the polos on the right head is preserved. The thin, wavy hair of the figures falls down from the shoulders. To the right of Hecate another figure, whose height reaches only to the waist of the goddess, is visible. A careful examination of this figure, from which only a small part survives due to the break on the left side of the stele, makes it clear that Hermes was depicted there (fig. especially 5b). The god holds a kerykeion (caduceus, the symbol of Hermes which features two snakes winding around an staff, often winged) in his left hand. Only a few traces of the left of his head and body are preserved, and his left leg is visible. It seems likely that the god was depicted with a short and curly hairstyle. It is worth noting that Hermes is depicted as shorter than Hecate. This stele dates from the $2^{\text {nd }}$ or $3^{\text {rd }}$ centuries A.D.

After Apollo, the goddess Hecate is most frequently associated with Hermes. Hecate as well as Hermes conducts the souls of the dead to the Underworld, both protect gates and city entrances. Hermes Enodios as well as Hecate Enodia (Trioditis, Trivia) protects and guards the roads and both of

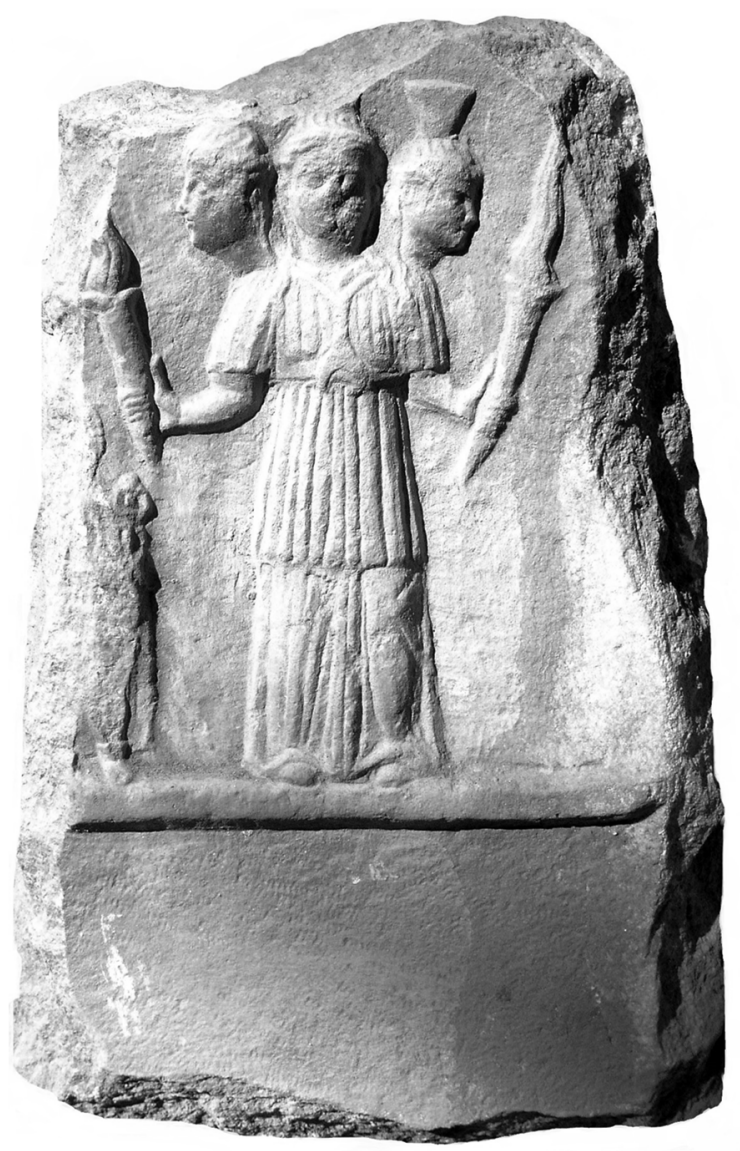

Fig. $5 c$ them supervise the crossroads (Kehl 1988, 320). Both gods are in contact with the underworld. For the close relation between Hermes and Hecate, see Lautwein 2009, 224-229 (Hermes und Hecate) and Brahms 1994, 155-156; also see Kraus 1960, 63; 71; Sarian, LIMC VI 1, 1008 s.v. G. La triple Hécate et Hermès (ou Priape). Hermes is also attested separately from Hecate in Lydia, see Paz de Hoz 1999, 15, 62, 64, 70, 85, 202-203 no. 23.1-3. It is probable that the god existed even in the Lydian Period, see Crawford - Greenewalt 2010, 238-240. An inscription on a statue base in Tralleis records that a priest of Hecate dedicated

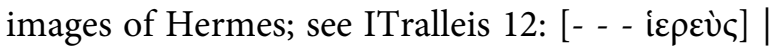

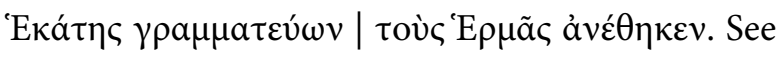

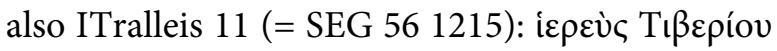

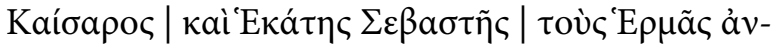
$\varepsilon \theta \eta \kappa \varepsilon v$. It is clear that Hermes and Hecate are depicted together in Asia Minor. These two gods stand side by side on some monuments I have recorded in various museums and my studies of them are still in progress. 


\section{A large inscribed stele (Figs. 6 a-c)}

\section{An epigram of a prayer for Hecate}

White marble; Inv. No.: 1232; (old no: 454) Find-spot: Maionia (Gökçeören village [formerly Menye])/Kula/Manisa; $H .: 124 \mathrm{~cm}$; L.: 37-42 cm; $D: 8 \mathrm{~cm}$; $L H .: 1,8 \mathrm{~cm} ; 1 \mathrm{~cm}$ (first line).

Ed.: Herrmann - Polatkan 1961, 125-126 no. 15 pl. IV; Herrmann, TAM V 1, 170 no. 523; Usman Anabolu 1988, $128 \mathrm{fn} .58$ (but the footnote is totally blank and the publication meant to be cited is apparently Herrmann, TAM V 1); Malay 1994, 56 no. 84 (inscription not given); Merkelbach Stauber 1998, 464 no. 04/22/01; Paz de Hoz 1999, 195 no. 19.1 and 68-69.

This stele has a regularly shaped pediment with a simple profile. On the corners of the pediment are acroteria ornamented with plant motifs. The side acroteria are complete, but the top acroterion is broken. On the left side of the pediment is a small crack. Inside the pediment is a depiction of a patera and in the inner sections of the corners are stylized heart-shaped leaf ornaments. On the shaft of the stele a large wreath composed of bay leaves carved in high relief is located in the middle and close to the pediment. A wreath is a popular motif on Lydian stelai. Above the wreath are three lines of a Greek inscription. They begin directly below the pediment, while four further lines are carved below the wreath. The inscription is neatly carved and complete. No other ornaments are on this stele. There is a dowel in the lower part of the stele. ${ }^{38}$

Herrmann and Polatkan date the inscription (and accordingly the stele) to the $2^{\text {nd }}$ century A.D. This stele is a dedication to Hecate in form of a prayer in verse. Its metre is hexameter, but the first verse is hypermetric (so Merkelbach - Stauber).

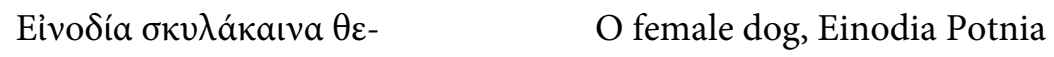

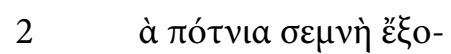

noble goddess,

$\chi \varepsilon \pi \alpha \sigma \tilde{\omega} v$

the most eminent above others

wreath

wreath

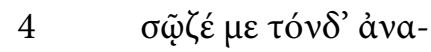

save me, who dedicated (this)

$\theta \varepsilon ́ v \tau \alpha$ кaì $\varepsilon \dot{\imath} \lambda \varepsilon \omega \varsigma$

and be merciful to those

6

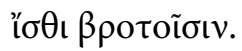

who are mortals!

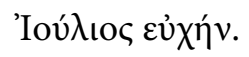

Iulius (dedicated this) as a vow.

The epigram reads as below:

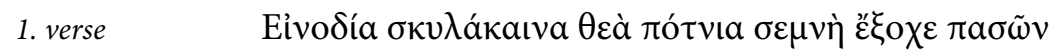

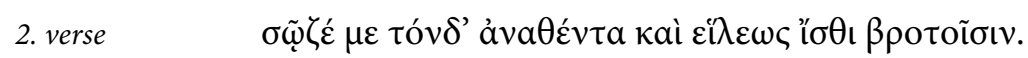

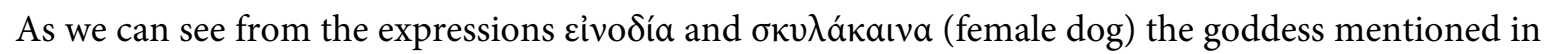
the epigram is Hecate. ${ }^{39}$ The inscription is a dedication of a certain Iulius. He prays to the goddess

\footnotetext{
${ }^{38}$ As the monument is stored in the museum in an inappropriate position amongst many other stone monuments, its lower part is not recorded on the photograph.

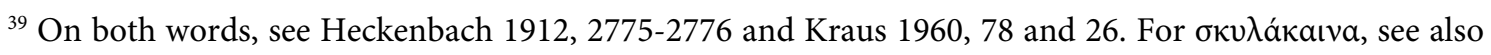
Greenewalt - Payne 1978, 43 fn. 12.
} 
for his own salvation and for the goddess' mercy to all mortals. M. Paz de Hoz thinks that the unusual wording, otherwise unknown in Lydian dedicatory inscriptions, may be due to the poetic character of the inscription. That the phrase 'Thea Potnia' usually employed for Meter, in this epigram is also used for Hecate is explained by her with the assumption that in this inscription an Anatolian goddess is meant by Hecate. She also points to the possibility that the poetic character of the hex-

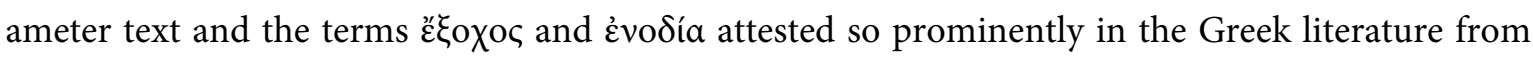
earlier periods may indicate traces of a pure Greek cult. Herrmann and Polatkan underlined that this is the first Hecate inscription discovered in Lydia. They proposed that this inscription, together with coins minted by this city and two uninscribed Hecateia ${ }^{40}$ provide strong evidence that a sanctuary of Hecate had existed in Maionia. ${ }^{41}$ For Hecate Enodia see Kraus 1960, 78-81. For Enodia in general see Jessen 1905; Chrysostomou 1998; Zeleny 1999, 56-65.
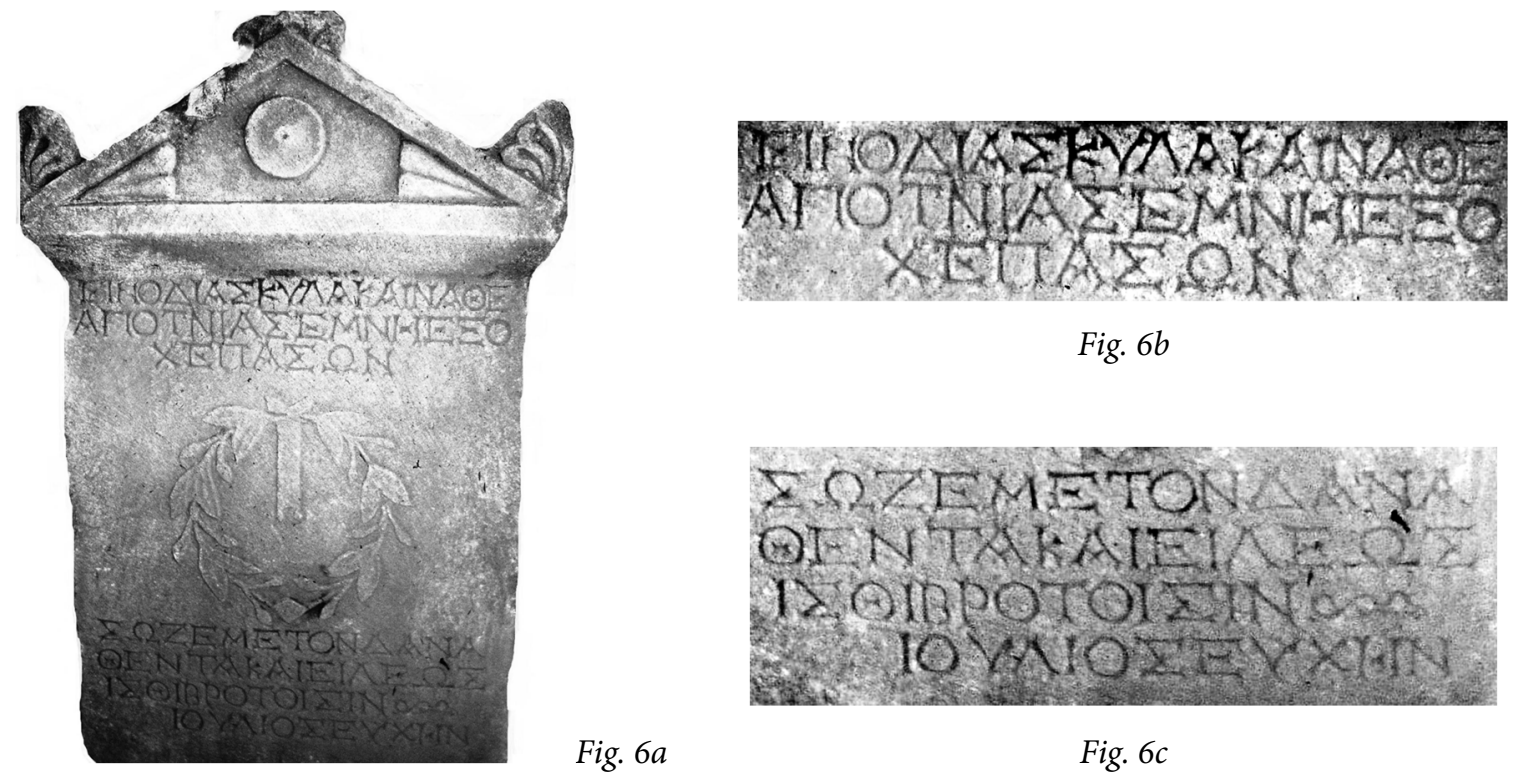

Fig. $6 b$

Fig. $6 a$

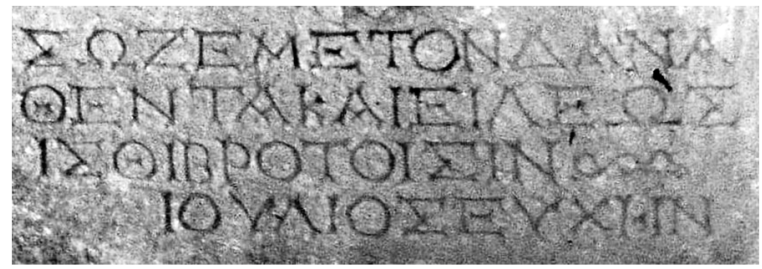

Fig. $6 c$

\section{Satala}

\section{Stele with relief (Figs. 7 a-c)}

Marble; Inv. No.: 433 (old no: 869); Find-spot: The inventory book records no information about its provenance; it only says that it is a donation to the museum. According to L. Robert (p. 113-114), it was found in Satala (Adala/Manisa) in the north of the Sardes Plain.; $H .: 42 \mathrm{~cm}$; height of the goddess figure: $30 \mathrm{~cm}$; L.: $37 \mathrm{~cm}$; D.: 7-8 cm.

Ed.: Robert, Hellenica X, 1955, 113-117 no. 22, lev. 15,1; Kraus 1960, 52 fn. 250; Greenewalt Payne 1978, 44 fn. 15; Sarian, LIMC VI 1, 995 no. 67; Werth 2006, 476-477 no. 425. The picture is given in Akyürek Şahin 2006, 60 fig. 1. Durugönül et al. 2015, 145-146 no. 84.

${ }^{40}$ The monuments, which Herrmann and Polatkan mentioned $(1961,126)$ as Hecataia, are in fact the monuments with Hecateion reliefs listed here under nos. 4 and 5.

${ }^{41}$ Herrmann - Polatkan 1961, 126: 'Durch diese Dokumente, zusammen mit den Münzbildern, kann das Vorhandensein eines Hekate-Heiligtums in Maionia als gesichert angesehen werden.' 
This stele is worked on a thin plaque and it seems that it originally continued on the left part of the stone. But there are no criteria to estimate how large the missing part is. On this firstly a thick and then a thin vertical profile appear. Possibly two stelai were carved side by side on this plaque. The

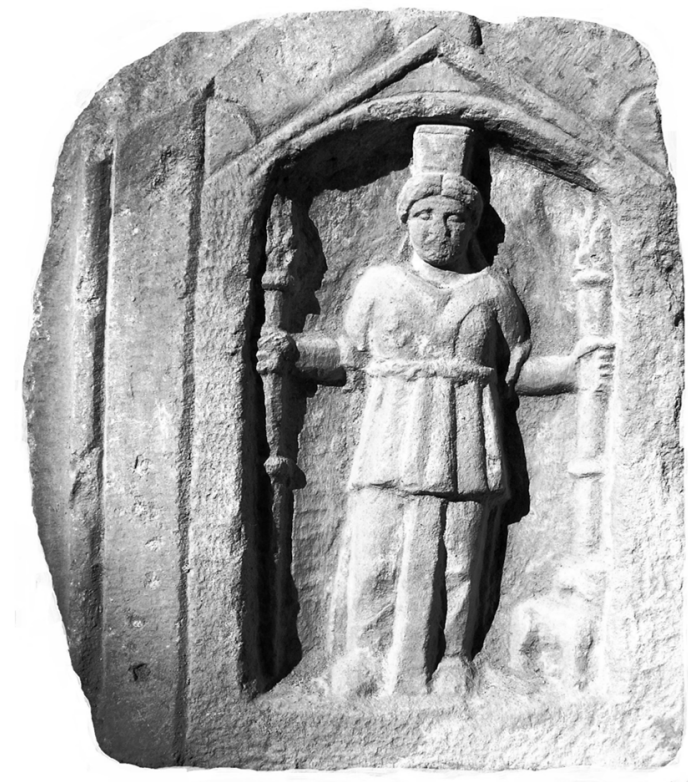

Fig. $7 a$ preserved part of the stele is designed as in the form of a naiskos. An area similar to a niche inside the pediment is carved. The arched part of the niche borders the pediment. The corners of the stylized pediment are decorated with acroteria. The top acroterion is rounded and broken away.

A passion for symmetry and rough work characterise the stele. Near the goddess' left foot stands a dog (on the dog, see above cat. no. 1).

The goddess holds a long torch in each hand. The flames of the torch are vigorously burning. On the shaft of the torches there are bracelet-shaped ties to keep the bunch of brushwood forming the torch together. The goddess' arms were arranged symmetrically and stretched out in a right angle from the body.

The goddess wears a short-sleeved peplos and her dress is tied with a belt below the chest. The pleats of the dress are carved with broad folds and the legs are roughly visible below the dress. The ends of the feet are clearly elaborated. The mouth and nose of the goddess are damaged. Her eyes are worked only superficially. She wears a high polos on her head and her hair is parted in the center and rolled up at the nape of the neck. Part of the hair at the nape of the neck falls over the shoulders.

On this relief the goddess is depicted with only one body. Robert pointed out that it is nearly impossible to identify a one-bodied goddess on reliefs or coin images with Hecate irrefutably (Robert, Hellenica X, 1955, 116-117 = Kraus 1960, 30-31); for those monuments which could possibly be associated with Hecate, see here no. cat. no. A. Robert postulated that two torches and dog were needed in order that one could with absolute certainty determine a single-bodied goddess as Hecate. Even though Robert thinks that this is a depiction of Hecate, it is still hard to claim this with certainty. Single-bodied Hecate depictions are mostly documented prior to the Roman Imperial Period; a large number of examples are given in Sarian, LIMC VI, 989-998. The goddess is also depicted single-bodied on the coins. 


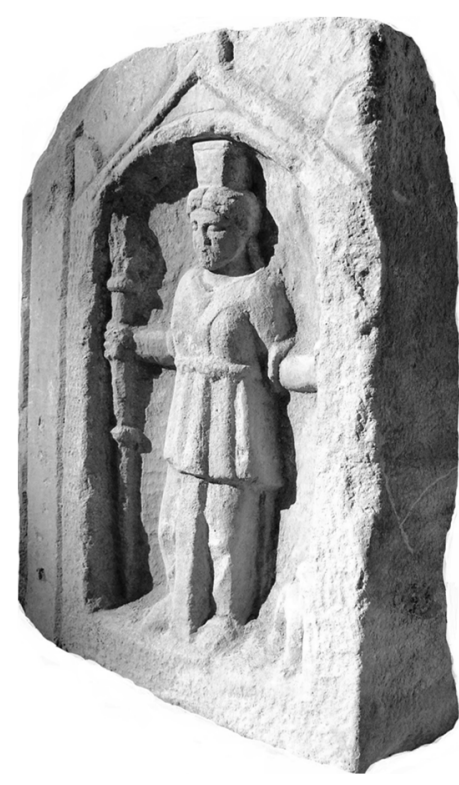

Fig. $7 b$

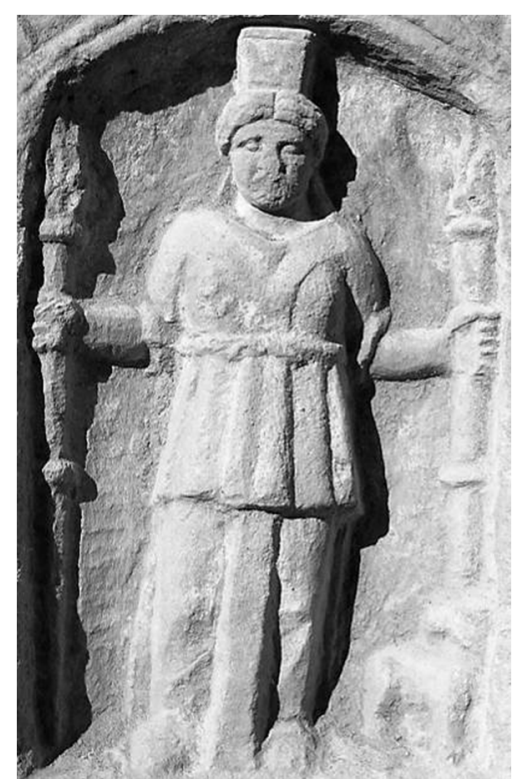

Fig. 7c

\section{Thyateira}

\section{Inscribed altar fragment (Fig. 8)}

\section{A dedication to Hecate, the Emperor Antoninus Pius and the Empress Faustina}

White marble; Inv. No.: 8083; Find-spot: Dağdere in the territory of Thyateira/Manisa (a village in the mountainous district between Thyateira, Iulia Gordos and Attaleia); H.: $66 \mathrm{~cm}$; L.: $40 \mathrm{~cm}$; D.: 15 cm; LH.: 1,5-2 cm.; H.: $66 \mathrm{~cm}$; L.: $40 \mathrm{~cm}$; D.: $15 \mathrm{~cm}$; LH.: 1,5-2 cm.

Ed.: Malay 1999, 47-48 no. 36 fig. 36; SEG 491554.

The altar is broken at the top and at the bottom. Base and capital are missing. On the shaft of the altar a well-preserved inscription of eleven lines is written. The inscription is carved within a frame of thin moulding profiles, but the last line is beneath the moulding profiles on the marginal border. The inscription is neatly carved and only in one instance a ligature is used. Malay finds it reasonable to suppose that there might have been a figure above the frame.

$\Theta \varepsilon \tilde{a}{ }^{` E \kappa a ́ \tau \eta ̣ ~} \sigma \omega \tau \varepsilon i ́ p \eta ̣$

2

4

6

10

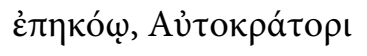$$
\sum \varepsilon \beta a \sigma \tau \tilde{\omega} \text { 'A } \delta \rho \alpha v \tilde{\omega}
$$

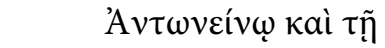

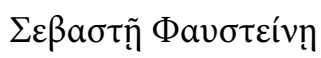

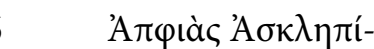

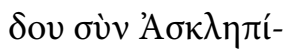

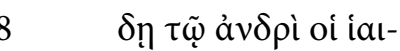

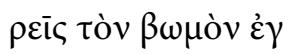

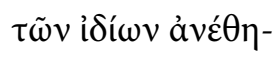

"For the Goddess Hecate, the attentive

Saviour, and to the Imperator

Augustus Hadrianus

Antoninus, and to Augusta Faustina Apphias, daughter of Asklepides and her husband Asklepides, the priests, set this altar up at their own expenses.

kav. 


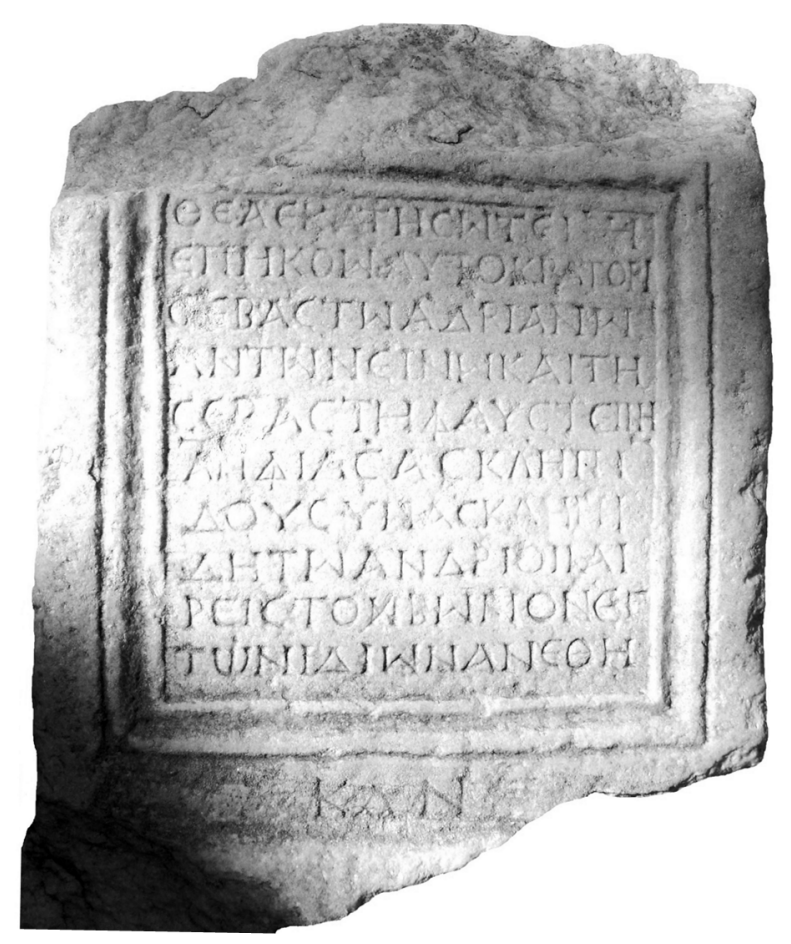

Fig. 8

The inscription dates from the time between A.D. 138, the year when the empress Faustina received the title 'Augusta' titel and A.D. 141, the year she died (Malay). For some epigraphic notes, see Malay 1999, 47.

This is the second inscription concerning the cult of Hecate in Lydia, which has come to light until now.; for the first one, see above no. 6. The priestess Apphias and her husband, a certain Asklepiades, dedicate an altar to Hecate and the imperial couple, Antoninus Pius and his wife Faustina (the Elder). Since the priestess, mentioned first, is the actual donor, whereas her husband is only a codedicant, we may guess that she is the priestess of a local Hecate sanctuary situated in a mountainous region at some distance from the city of Thyateira. It is quite possible that her husband, who was also a priest, performed the emperor cult in this settlement. This may explain why the imperial couple is mentioned. First and foremost the donation of this altar is a thank-offering to Hecate, who is called $\sigma \dot{\omega} \tau \varepsilon\llcorner\rho \alpha \dot{\varepsilon} \pi-$

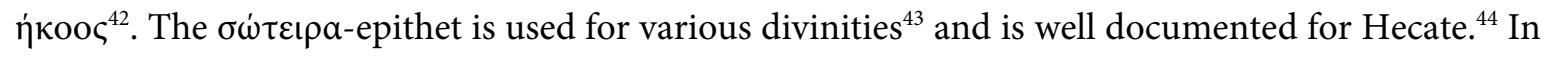
Carian and Phrygian inscriptions, the goddess is occasionally named with this epithet, sometimes on its own. Hecate, having magical powers and having spirits around her, is also a chthonic deity. This aspect of the goddess can be clearly observed on the Hecate monuments found in the Tembris (Porsuk) valley in Phrygia. Hecate was believed to have taken the souls of the dead out of the underworld, which leads T. Lochman to think that the 'Soteira' was conferred upon her for that rea$\operatorname{son}^{45}$. But in this inscription there is not the slightest indication that this is a chthonic Hecate. In the curse formulae of incriptions particularly found in the Porsuk Valley (Kütahya/Altıntaş Plain) Hecate is attested as a chthonic goddess. Lochman finds it striking that Hecate was acclaimed with

${ }^{42}$ For Soteira, see in general Höfer 1909-1915, 1236-1247, s.v. Soteira; Kehl 1988, 316; Johnston 1990: in this publication no direct information is given concerning the soteira epithet of the goddess. Although the

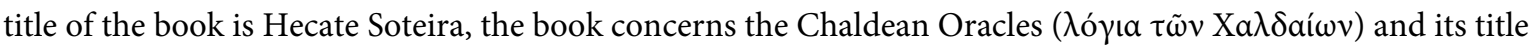
is therefore misleading.

${ }^{43}$ For examples cf. Martin 2003. Even though Soteira is mostly used as an epithet of a divinity, in some inscriptions a goddess is solely and exclusively invoked under the name of Soteira, see for example the documents in Lydia, Paz de Hoz 1999, 266-267 no. 454.1 and 54.2. But, as Paz de Hoz points out, Soteira is presumably employed in these inscriptions as the epithet of a main goddess who was worshipped in those areas where these votive offerings were discovered, Paz de Hoz, ibid., 20 fn. 90.

${ }^{44}$ Höfer 1909-1915, 1241-1243, s.v. VIII. Hekate. For a few examples, see Habicht 1969, 131-132 no. 119; Pfuhl - Möbius 1979, 502-503 no. 2089-2091; Lochman 1990,2, 463-464; Drew-Bear et al. 1999, 324 no. $519=$ Lochman 2003, 285 no. II 467.

${ }^{45}$ Lochman, 1990,2, 463-464. 
the epithet 'Soteira'. ${ }^{46}$ In these inscriptions she also carries the title of 'melaina ( $\mu$ ćlaıva = black)', which must be understood to mean that she was expected to frighten and to repel those who dared to rob the graves or to damage them. In Lochman's opinion, it indicates that Hecate also had a frightening side; whoever put his/her grave under the protection of this goddess wanted to avoid the dark side of death. Lochman emphasizes that the goddess has evil dark powers but at the same time the character of a saviour, and that both aspects were linked with each other. According to Lochman, a three-bodied Hecate depiction was placed on the grave stone of the dead man, who in this way was dedicated to the goddess. ${ }^{47}$ L. Robert also discussed this epithet, pointing out that such votive inscriptions for Hecate are particularly documented in Uşak and its surrounding, i.e. in Phrygia. ${ }^{48}$ The name of the goddess appears not only in votive inscriptions but also in grave inscriptions in Uşak and in its surroundings. ${ }^{49}$ Coming back to Hecate Soteira, to whom the priestess dedicated the altar as a thank-offering, the linkage between the goddess and the imperial couple makes me conclude that in this case the Saviour Hecate was not venerated for her connections with the underworld and the dead but for her assistance in earthly matters. Coins minted by pleaides Phrygian Apameia call Hecate Soteira and testify that even city-states venerated the goddess for her help in times of great distress ${ }^{50}$. The epithet of $\dot{\varepsilon} \pi \eta$ koo has been attested for a number of god and goddesses. For a Hecate epekoos from Odessos (Varna), see Kraus 1960, 163. For Ourania see ibid., 59.

\section{Monuments in the Manisa Museum whose provenances are unknown}

\section{A small stele Fragment (Figs. 9 a-b)}

White marble; Inv. No.: 77; Find-spot: Unknown (donated to the museum); $H .: 18 \mathrm{~cm} ; L .: 21 \mathrm{~cm}$; D.: $4-5 \mathrm{~cm}$.

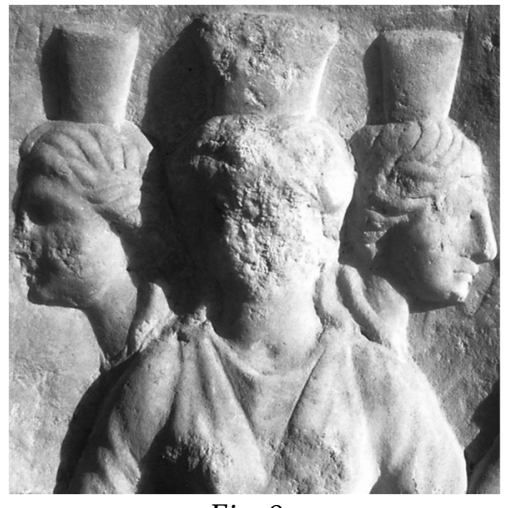

Fig. $9 a$

Ed.: Greenewalt - Payne (1978, 44 fn. 15) mentioned this stele and thought that it might have been found in the Hermos (Gediz) Valley. Durugönül et al. 2015, 146 no. 85.

The sides of the stele are roughly formed and its lower part is missing. The back is roughly smoothed. Due to the break, we do not know whether the stele had an inscription. This relief, as it is the case with other steles from Phrygia, seems to have been carved into a waste piece from the large marble quarries.

${ }^{46}$ Lochman 1990,2, 463-464.

${ }^{47}$ Lochman, ibid.

${ }^{48}$ See Robert, Hellenica X, 1955, fn. 2.

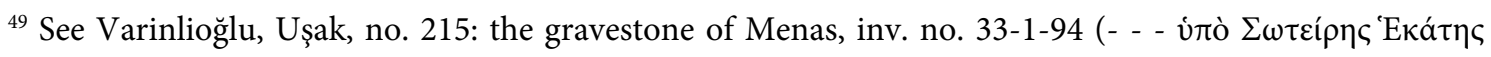

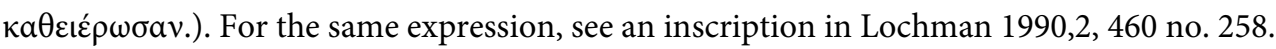

${ }^{50}$ Höfer 1909-1915, 1241, s.v. VIII. Hekate 1. Head, 1906, 88 no. 110-113 pl. 11,1. 


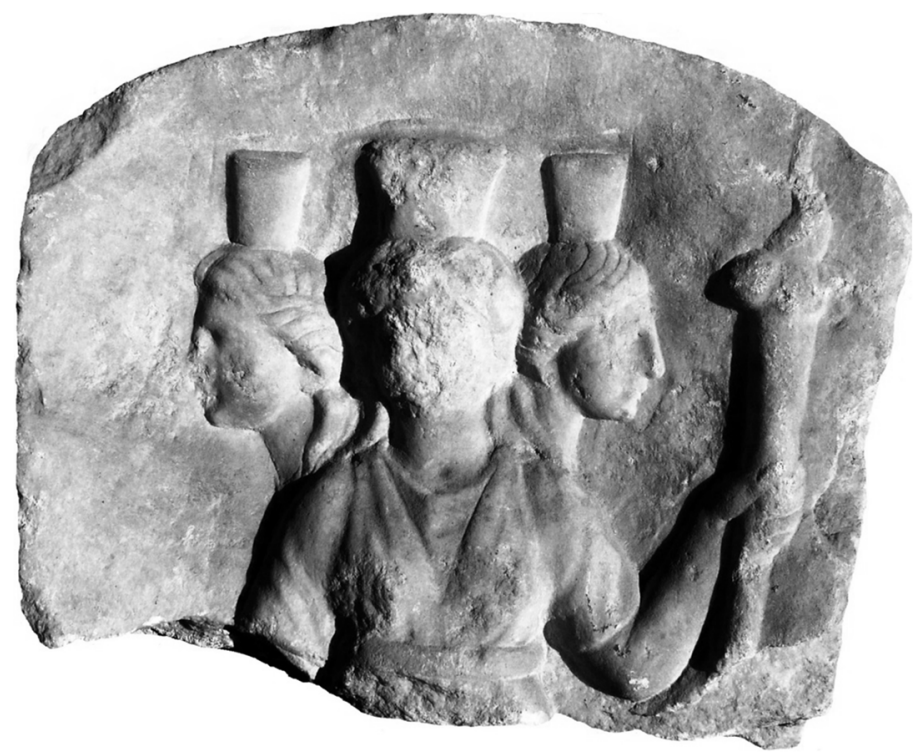

Fig. $9 b$

The stele does not have a pediment, its top ends with an uneven rounding. At the sides there are small breaks and damages. It seems that only Hecate is depicted, although the lower part of the stele is missing. Therefore, it is impossible to say whether there is a dog figure near the goddess' feet. Hecate is represented as three-bodied, but only the frontal body is shown; the heads of the other figures are placed on its shoulders and do not have visible bodies of their own.

The artist's intention was to depict three figures standing back to back. This sort of work, on which three heads are placed on one body, occurs also in cat. no. 5 above and is a common type of imagery. Only the frontal goddess has a torch in her left hand. Her short-sleeved peplos is wrapped by a broad belt below the chest. The folds of the garment are quite naturally arranged. All three heads of the goddess wear a high polos. The frontal face of the frontal goddess is damaged. The hair falls down to the shoulders and is neatly combed.

The stele dates from the Roman Imperial Period.

\section{Fragment of a Hecateion (Figs. 10 a-d)}

Marble; Inv. No.: 361; Find-spot: Unknown (donated to the museum); H.: $33 \mathrm{~cm}$; L.: $23 \mathrm{~cm}$; D.: 23 $\mathrm{cm}$.

Ed.: Greenewalt - Payne (1978, 44 fn. 15) merely mentions this Hecateion; Usman Anabolu 1987, 50 res. 2; Usman Anabolu 1989, fig. 10 (In both publications an incorrect inventory number [373] is given). Durugönül et al. 2015, 147 no. 86 .

Broken above and below. The heads of the goddesses and the lower parts of the shaft are missing. The surface of this Hecateion is much worn. It is composed of three women figures standing back to back. The figures stand frontally and their arms are lowered.

One of the figures has a snake coiling in both her hands (figs. 10b and 10d). This figure, which attracts the attention of the viewer, appears to be designed as the main figure. On the left arm the snake is quite visible; it coils up along the arm and reaches the body at the belt of the peplos and thereafter creeps up to the shoulders. Most likely the head of the snake is at the level of the shoulder. Because the right arm of the figure is damaged, the body of the snake is not preserved; the 
head, however, is visible around the right shoulder of the figure. All three figures wear short-sleeved and loose peploi. Buttons on the short sleeves of the peplos are visible. The garment is V-shaped and loose and is fastened to the body with a thin belt below the chest. The folds of the garment are rendered as vertical pleats.

The pleats of the cloth, and the apoptygma (the loose upper part of the cloth) pulled slightly forward in the middle of the body, evoke Hecateia formed in archaic style, even though this Hecateion is roughly and clumsily cut. For this type of Hecateia belonging (or not belonging) to the Archaic Age, see in general Petersen 1880; Petersen 1881; Kraus 1960, 84-152; Harrison 1965; Eckstein 1965; Willers 1990; Özgan 1999, 48-49 no. 16-17 pl. 11; Werth 2006, 35-105; Altun 2008. For Hecate in archaistic style, see Brahms 1994, 151-179. Even if this Hecateion has some features from earlier periods, it still dates from the Roman Period; possibly it may be a little earlier than the other Hecateia treated in this paper.

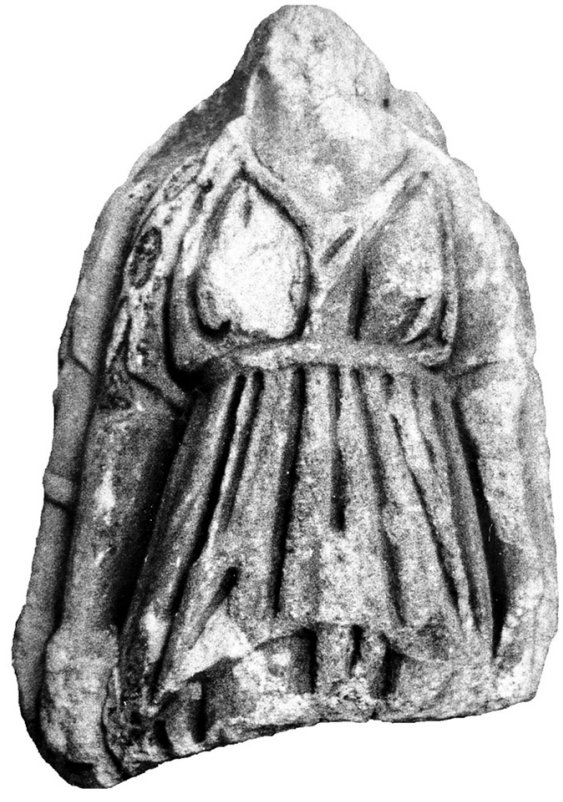

Fig. $10 a$

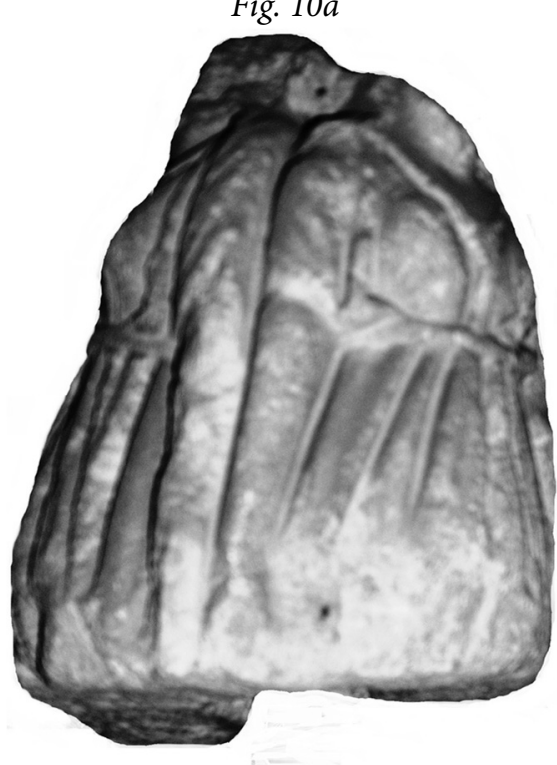

Fig. 10c

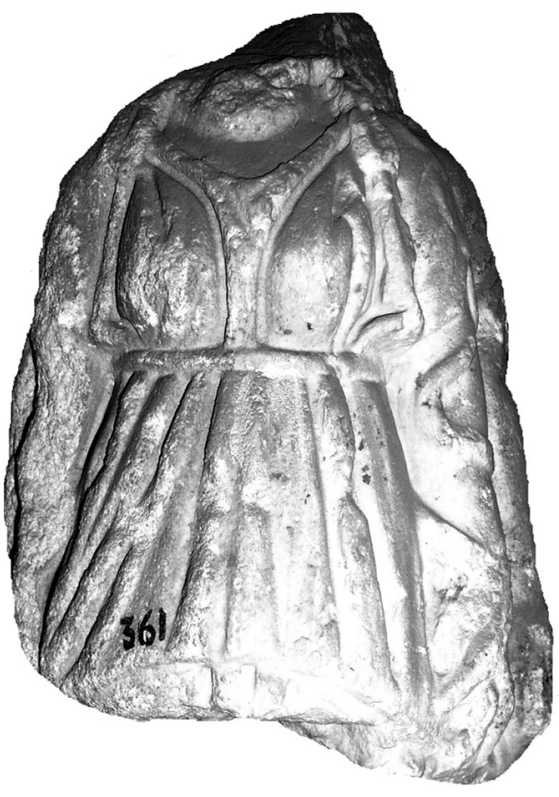

Fig. $10 b$

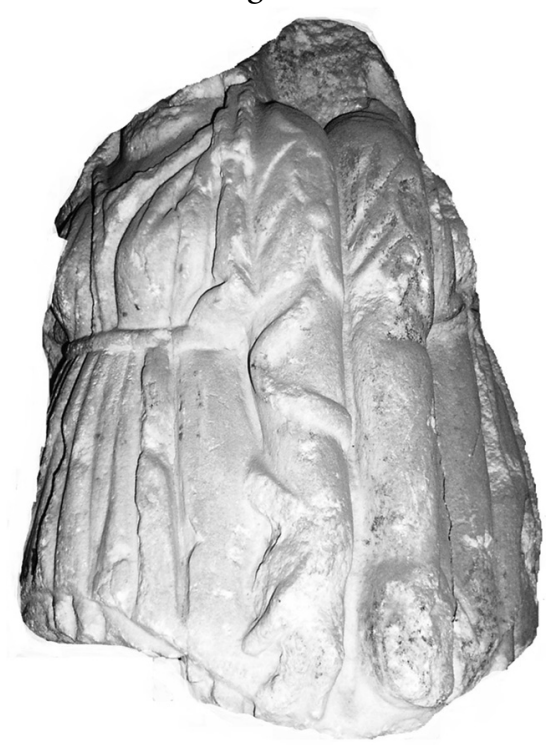

Fig. 10d 


\section{Fragment of Hecateion (Figs. 11 a-f)}

White marble; Inv. No.: 7062; Find-spot: Unknown (Confiscated and brought to the museum from Salihli/Pazarköy/Hacımuşlu farmstead); H.: ca. $28 \mathrm{~cm}$; L.: $16-17 \mathrm{~cm} ; D .: 23-24 \mathrm{~cm}$.

Ed.: Durugönül et al. 2015, 148 no. 87.

This small Hecateion is broken above from the shoulders and the heads are missing. It has a cylindrical shape and does not have a high base. In many places there are small breaks and traces of weathering. The Hecateion consists of three female figures, in relief, worked frontally and standing back to back. Some further figures are also carved in addition to the women figures, worked in relief near the feet of the three figures. One is a small sitting dog (fig. 11f) (for the dog see above cat. no. 1), the others are a small standing creature, probably a ram (figs. $11 \mathrm{~d}$ and 11e), and the last is a urn-like cube (figs. 11a and 11c). Handled vessels or cubes are rather unusual attributes of Hecate.

The arms and hands of the figures of the goddess are much worn and partly broken. It is not clear what some of the figures hold in their hands. One holds a handled vessel, possibly of metal, similar to a basket held in her left hand (fig. 11f). Another figure probably has a torch in her hand (fig. 11d, the figure on the left). The third one carries a cup, presumably a phiale (fig. 11c). However, these objects cannot be clearly distinguished due to the bad state of preservation.

All three goddess figures wear peploi and the ends of their feet are visible outside the garment. The goddesses are standing in classical contraposto and the folds of the dress are shaped accordingly; they are carved in the form of thin parallel lines.

The Hecateion probably dates from $2^{\text {nd }}$ century A.D.

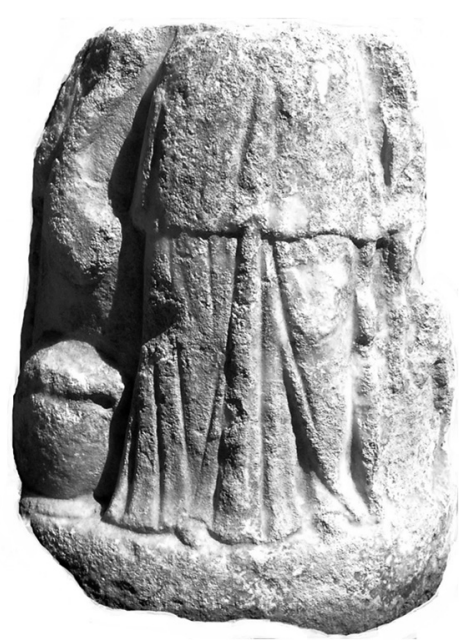

Fig. 11a

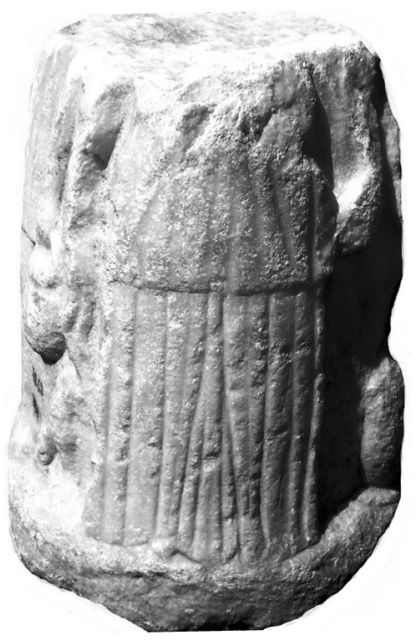

Fig. $11 b$

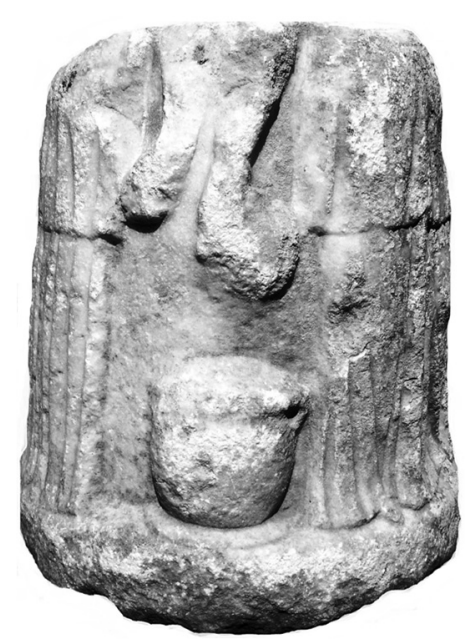

Fig. 11c 


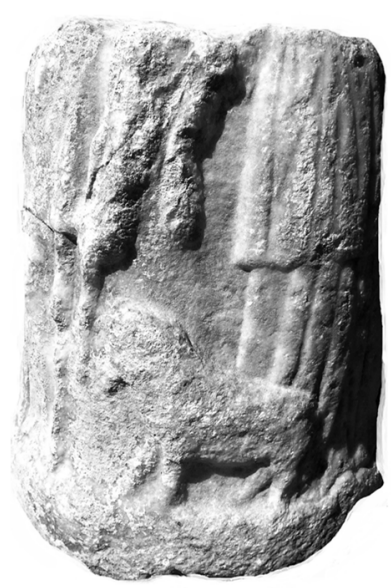

Fig. 11d

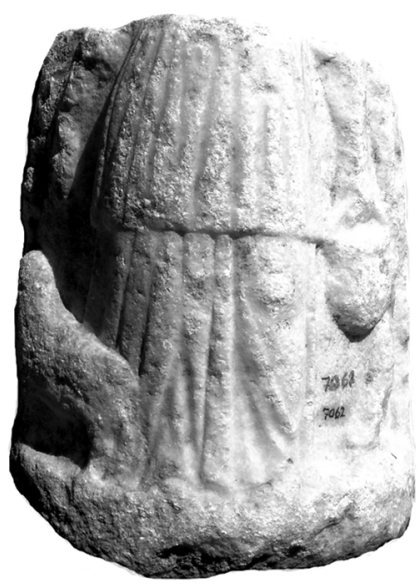

Fig. 11e

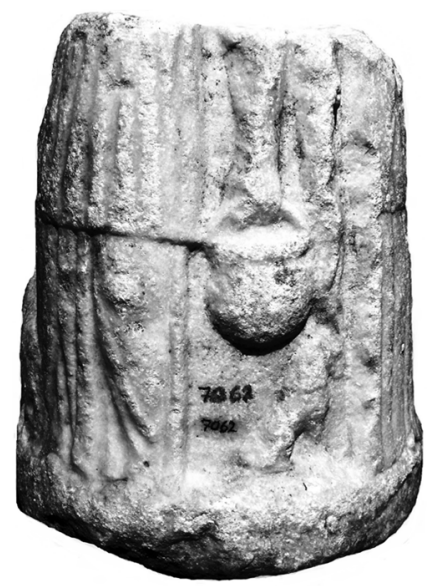

Fig. $11 f$

\section{Fragment of a Hecateion (Figs. 12 a-e)}

Marble; Inv. No.: 7938; Find-spot: unknown (purchase); H.: $36-37 \mathrm{~cm}$; L.: (shaft) $20 \mathrm{~cm}$; (base) 24 $\mathrm{cm} ; D .: 15-16 \mathrm{~cm}$.

Ed.: Durugönül et al. 2015, 149 no. 88.

Broken nearly all round. Mostly broken above and below. The surface is abraded and has small damages. The upper part of the shaft and the heads of all the figures of the goddess are missing. This Hecateion has a high base. On the base three figures are standing back to back. One is designed as

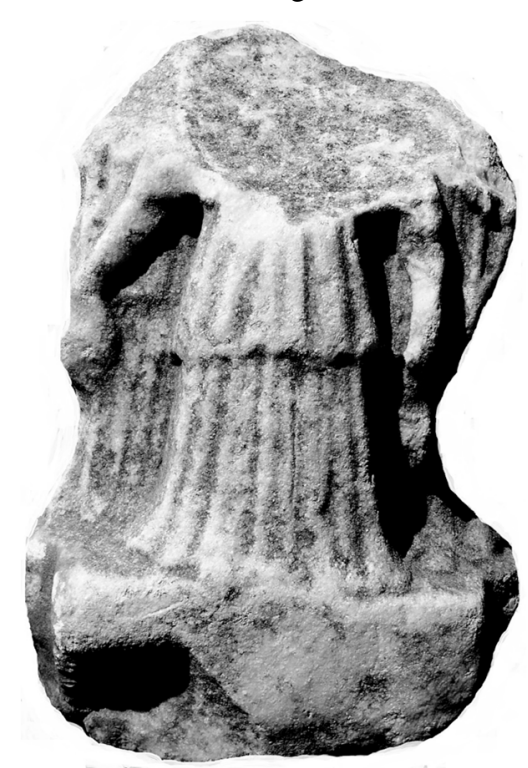

Fig. $12 a$ the main figure (fig. 12a); ${ }^{51}$ its posture is strictly frontal. The other figures are positioned next to the main figure and they are depicted in profile (figs. 12b-c and 12e).

Only one arm of the half figures is cut. The part which is understood as the back of the Hecateion, is left rough (Fig. 12d). All three Hecate figures join hands, but only four arms are seen in the whole composition. As well as holding each other's hands, the figures hold an object at the same time, which cannot be distinguished clearly due to the state of preservation (especially figs. 12b and 12e). All of them wear a richly pleated and short-sleeved peplos. Even though this Hecateion suffers badly from abrasions and breaks, it is evidently not elaborately worked.

Probably from the $2^{\text {nd }}$ century A.D.

${ }^{51} \mathrm{D}$. Willers remarked that none of the figures of any Hecateion are different from each other and there is no main figure, see Willers 1990, 301: 'Eine Hauptansicht und damit eine bevorzugte Figur war vom entwerfenden und ausführenden Bildhauer, wie bei allen Hekateia, nicht vorgesehen.' One can claim that this opinion of Willers is at least not valid for three-dimensional Hecateia dating from the Roman Period. It is evident that one of the three figures is the main one in many examples, see for instance here cat. no. 14 (fig. 14 a-c) and Hecateion (fig. 14d); cat. no. 10 (fig. 10 a-d) and even cat. no. 13 (fig. 13 a-b). 


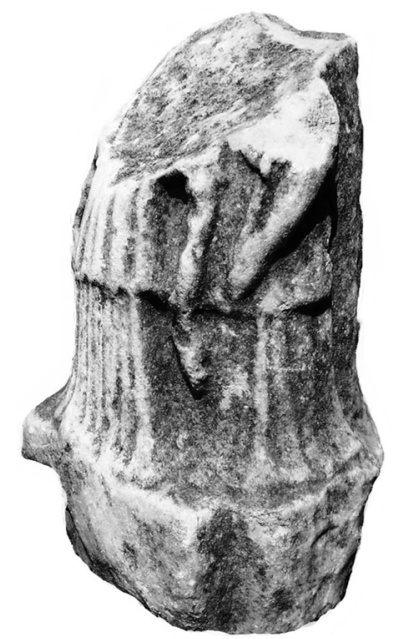

Fig. $12 b$

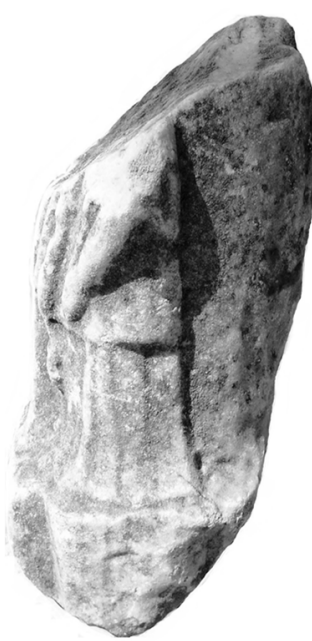

Fig. $12 c$

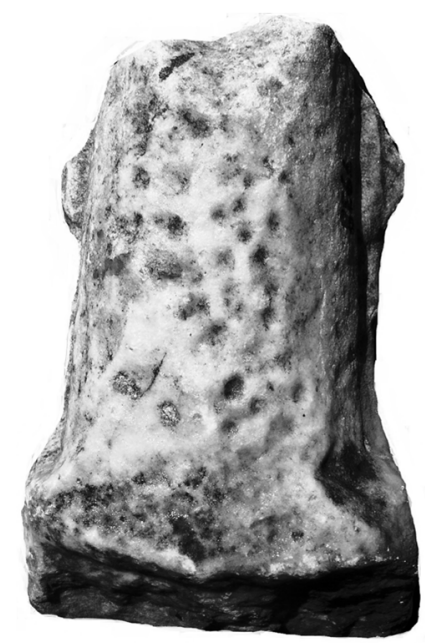

Fig. $12 d$

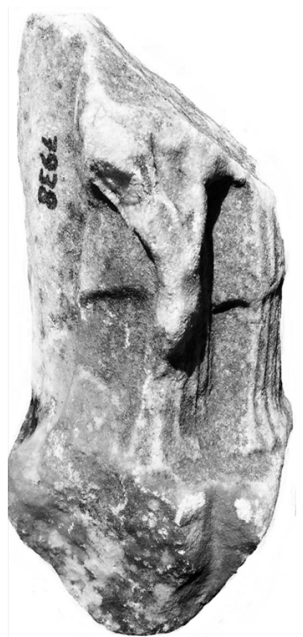

Fig. $12 e$

\section{Hecateion (Figs. 13 a-b)}

White marble; Inv. No.: 8677; Find-spot: unknown (confiscated and transferred to the museum); H.: $29,5 \mathrm{~cm} ;$ L.: $14-15 \mathrm{~cm} ; D .: 4-5 \mathrm{~cm}$.

Ed.: Durugönül et al. 2015, 149-150 no. 89.

The Hecateion is complete apart from the right figure's broken stephane $e^{52}$. It has a small damage and a dense yellow-brown patina. Under a lime deposit milk-white marble emerges. The base is low. All three figures of the goddess Hecate are standing side by side; but we can assume that the artist intended a composition of three figures standing back to back. This may be deduced from the fact that the main figure is placed in a full frontal position, while the side figures are worked in form of half-bodies. The back of the Hecateion is roughly smoothed (fig. 13b). The vertical marks of the stonecutter's chisel are visible.

All three figures hold a short torch in their hands. Due to the fact that the side figures are carved in the form of half-bodies, only one arm of each is visible, and therefore only four torches are depicted. While the peplos, belt and folds of the central figure are worked in detail, and distinctively, the side figures are cut quite imprecisely. The oval faces of the figures are frontal; the left figure has a largish face. The facial features are indiscernible due to the lime deposit. Their hair is depicted as large round locks above the forehead. They each carry a high stephane on their heads. Between the heads of the three figures there are small oval holes. A polos-like object rises at the back of the central figure's stephane. By this means this Hecateion gains a compositional centre (Werth 2006, 113 fn. 411).

The monument, characterized by its strict symmetry and its careless execution, probably dates from the $3^{\text {rd }}$ century A.D.

On the base of its iconographic features this Hecateion is of Phrygian origin. Even though it was found in Lydia, due to its style it certainly came from Phrygia (see below no. 14).

${ }^{52}$ For stephane (crown) in general, see Filges 1999, 394-397. On the features of the crown in the Roman Period ibid., 396-397. Also see Akyürek Şahin 2011, 239. 
This sort of Hecateion is documented in Phrygia in great numbers. ${ }^{53}$ Hecate is mostly attested in

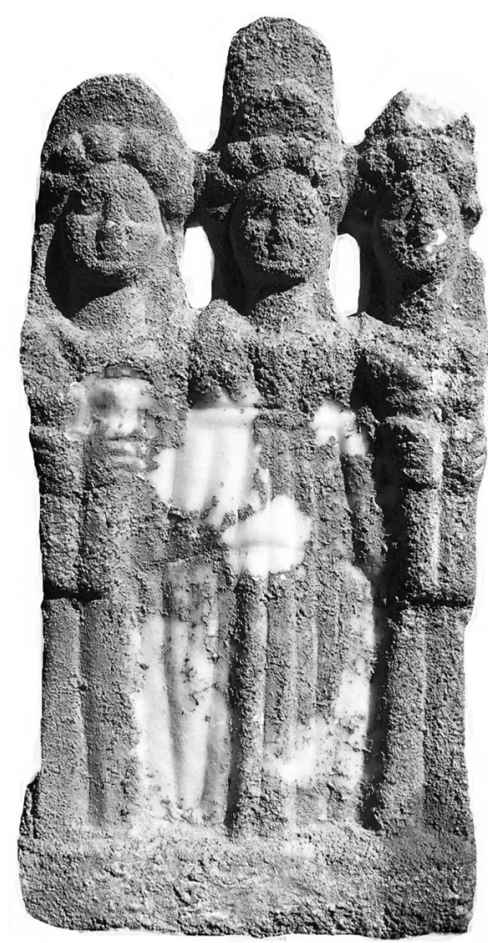

Fig. $13 a$

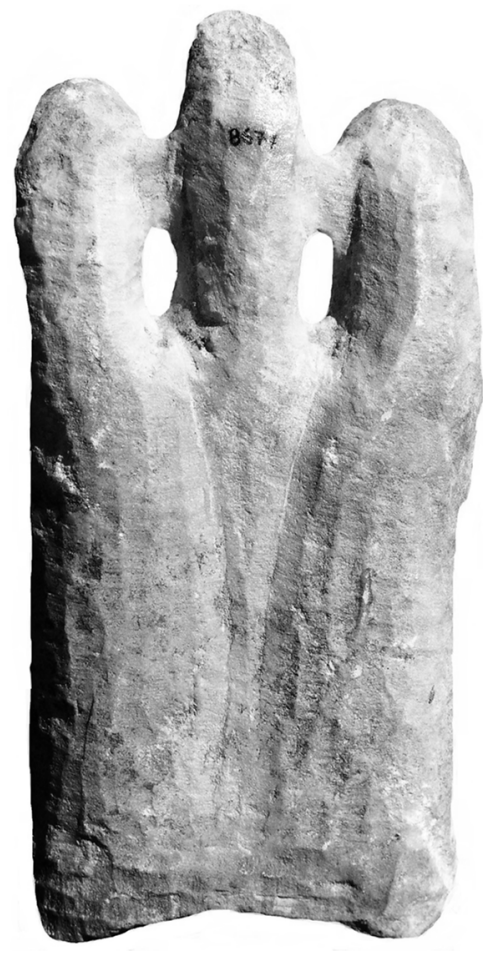

Fig. $13 b$ the ancient settlements of the Tembris (Porsuk) Valley and Akmonia. ${ }^{54}$ However, as many monuments stored in the museum depots indicate, the cult has traces in numerous parts of northwest Phrygia. The goddess is always depicted as three-bodied in accord with her evil character. She was worshipped as the goddess of the dead in that region and was regarded as a fearsome goddess. Her depiction was placed on the gravestones in order to preserve them. One can also say that the goddess has a relationship to Zeus, who was the god most worshipped in Phrygia. ${ }^{55}$

\section{Hecate Monuments Outside the Manisa Museum}

\section{Sardis?}

\section{Hecateion Fragment (Figs. 14 a-c)}

White marble; Paris, Musée du Louvre ${ }^{56}$, (donated to the museum in 1901 by. Gaudin); Inv. No.: MA 3249; Find-spot: Hanfmann ve Ramage: 'Allegedly from Sardis'; $H: 18 \mathrm{~cm}$ (height of the left head.: $11,7 \mathrm{~cm}$ ); L.: $17,5 \mathrm{~cm}$.

Ed.: Bulletin de la Société nationale des antiquaires de France (BSAF), 1901, 349 no. 50; Arch. Anz. 1902, 124, no. 50; Robert, Hellenica X, 1955, 115 fn. 3; Hanfmann - Ramage 1977, 165 no. 248 fig. 429-430; Greenewalt - Payne 1978, 44 fn. 15; Lochman 1990, 1, 461 fn. 31 B, p. 460 fig. 10; Lochman 1990, 2, 91 fn. 193.

${ }^{53}$ Plenty of Hekataia similar to this can be seen in the museums of Kütahya, Afyon, Eskişehir and Uşak, see above fn. 1 .

${ }^{54}$ For the traces in the Tembris Valley see Lochman 1990,1, 461 fn. $32=$ Lochman 2003, 198 fn. 16. For Akmonia see, Buckler - Calder, MAMA VI, no. 241; 245 and $402=$ Lochman 2003, 198 fn. 16. See in general, Lochman 2003, 90.

${ }^{55}$ An article on the Hecate cult in Phrygia is in preparation by me.

${ }^{56}$ For an earlier study concerning a group of Hecate monuments in the Louvre Museum, also containing some Hecate monuments originating from Asia Minor, see Michon 1892. 


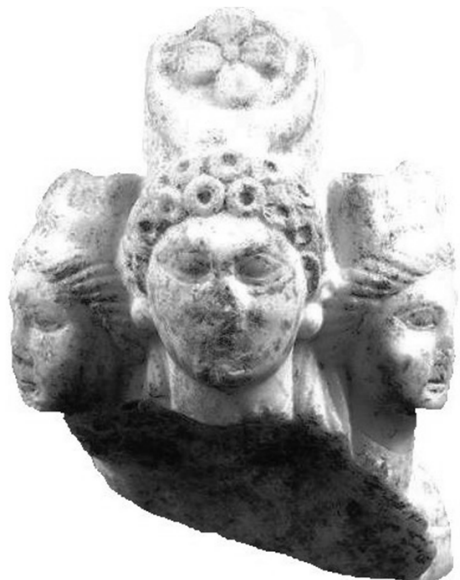

Fig. 14a: Excerpted from the following website: https://tr.pinterest.com/pin/53135445 6007851071/ (Access date: 21.04.2016).

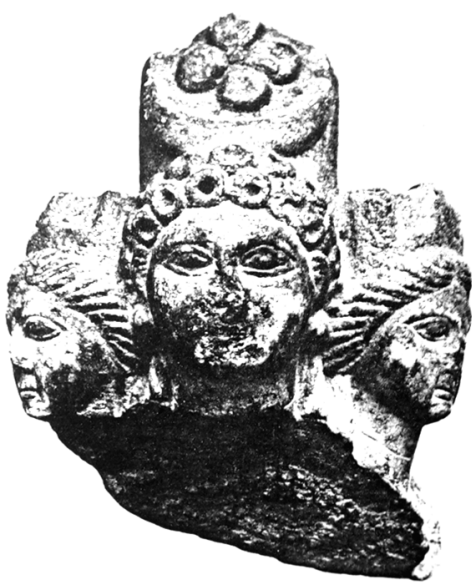

Fig. 14b: Hanfmann - Waldbaum 1975, fig. 429.n.

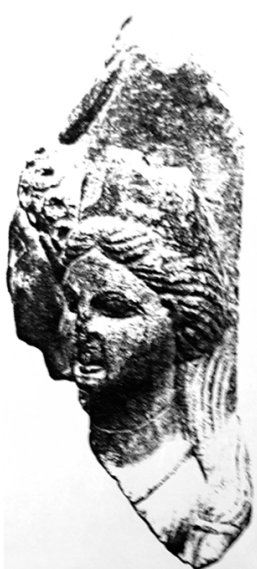

Fig. 14c: Hanfmann - Waldbaum 1975, fig. 430.

This fragment of a Hecateion comprises only the upper part (fig. $14 \mathrm{a}-\mathrm{c}$ ); shaft and base are missing. The three heads of the goddess are well preserved. The faces of the figures are oval and the cheeks are a bit chubby. The facial features are slightly eroded. The front figure, conceived as the main figure in the composition, faces frontally and has a hairstyle different from that of the side figures. The hair of the goddess is arranged in large, circular locks, framing the face; the hair of the side figures is arranged in horizontal parallel lines, and appears to have been combed backward. The hair of all the three figures falls down to the shoulders. The centre figure wears a high polos on her head. One can discern that the side figures carry mural crowns (corona muralis) (see above no. 4), despite the fact that they are rather abraded. On the front of the main figure's polos is the depiction of a large crescent that is oriented downward and a four-leafed rosette relief is seen in the middle of the crescent.

The jewellery of the figures attracts attention. Round earrings adorn the ears of the main figure. The right figure wears a necklace, which she appears to have worn tight around the neck. In general, the elaborate craftmanship and symmetry of this Hecateion is striking. It probably dates from the $2^{\text {nd }}$ or $3^{\text {rd }}$ centuries A.D.

This Hecateion, which according to publications was allegedly found in Sardis, is stylistically somewhat similar to the Hecateion preserved in the Rodin Museum ${ }^{57}$ in Paris (see cat. no. 14d). Even though the find-spot of the Hecateion in the Rodin Museum is not provided in any publications, ${ }^{58}$ its style indicates clearly that it is from Asia Minor. A group of Hecateia are recorded in the Kütahya Museum. ${ }^{59}$ Among these are in particular those discovered in the town of Altıntaş of Kütahya county, which are stylistically quite similar to the Hecateia above whose provenance was allegedly Sardis and also to the Hecateia preserved in the Rodin Museum. It is noteworthy that the hairstyle of the central figure and her polos ornamented with crescent and rosetta is almost identical. From

${ }^{57}$ Paris, Musée Rodin; Inv. No.: 65; White marble; Find-spot: Not provided in the publications; H.: 48,5 $\mathrm{cm}$; L.: 19,5 cm; D.: $10 \mathrm{~cm}$. This work belongs to the collection of antiquities of the famous sculptor A. Rodin.

${ }^{58}$ Frel 1967/68, no. 184 fig. 71; Mitropoulou 1978, 33 no. 6 and p. 68 fig. 25; Lochman 1990, 1, 461 fn. 31 A, 460 fig. 9; Lochman 1990, 2, 91 fn. 193; Sarian, LIMC VI 1, 1001 no. 162; Werth 2006, 376 no. 190.

${ }^{59}$ These monuments are in preparation for publication by me. 


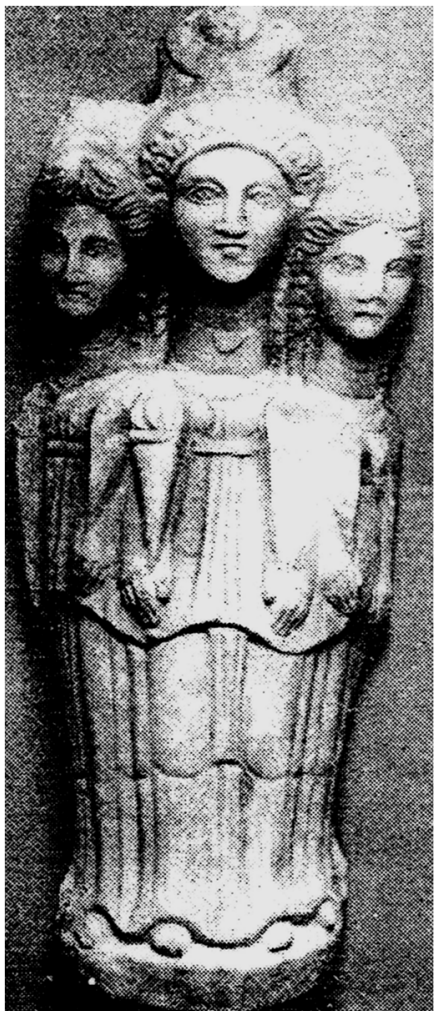

Fig. 14d: Hecateion in the Rodin Museum, Frel 1967/ 68, no. 184 fig. 71.

these observations, one can claim that both Hecateia (those in the Rodin and Louvre Museums) are of Phrygian origin (Altıntaş/Kütahya). As a matter of fact, this similarity of both Hecateia was already noticed by $\mathrm{T}$. Lochman and the provenance of these monuments was justifiably attributed by him to Phrygia (Tembris/Porsuk Valley) in $1990 .{ }^{60}$ As a result, the Hecateion, which I include in this catalogue because of its alleged find-spot (Sardis), is not of Lydian origin, even if it was found in Lydia according to the publications.

\section{Votive Stele with Relief (Figs. 15 a-b)}

Bluish-gray marble; Berlin, Antikensammlung, Staatliche Museen; Inv. No.: SK 688; Find-spot: Unknown, but possibly Maionia; H.: 54 $\mathrm{cm}$; L.: $27 \mathrm{~cm} ; D .: 12 \mathrm{~cm}$.

Ed: Petersen 1881, 65 d; Conze 1891, 256 no. 688; Kraus 1960, 52 fn. 250; Mitropoulou 1978, 46 no. 59 fig. 75; Sarian, LIMC VI 1, 1003 no. 194; Werth 2006, 396, no. 224.

Almost completely preserved (figs. $15 \mathrm{a}-\mathrm{b}$ ). Only the face of the centre figure is broken and the faces of the side figures are abraded, as is the whole surface of the stele. This stele of the aedicula type carries a Hecateion relief. The top of the stele is a little damaged and has an oval cutting. The pediment is placed on this oval-cut spot. Large side acroteria are at the corners of the high pediment. The topmost acroterium is decorated with plant motifs. On each side of the top acroterium a patera motif is carved. Inside the pediment there is a rough and almost round ornament of a crescent whose tips are oriented upwards. Within a slightly hollowed niche, a Hecateion covering the whole surface is depicted in low relief. The columns on each side of the niche and the capitals are coarsely worked. The goddess is depicted as three-bodied in this not very artfully executed Hecateion; the body on the front is seen as the principal figure and the other figures attach to it. The parts above the waist, faces and the arms of the side figures are visible. The dowel below the low base of the stele is broken and missing.

The side heads are also depicted frontally (en face). The goddess wears a long peplos and her garment is tied with a twisted belt. The folds are indicated by lines. All three figures spread their arms and hold short torches, whose flames are shown curling. The hair of the figures is parted in the middle over the forehead; they each wear a polos on their heads. The poloi are ornamented with vertical lines. The goddess has an ill-proportioned body. The symmetry employed on the stele is in general unsatisfactory.

This Hecateion dates from the Roman Imperial Age, possibly from the $3^{\text {rd }}$ century.

${ }^{60}$ See Lochman 1990, 1, 461 fn. 31; Lochman 1990, 2, 91 fn. 193. 


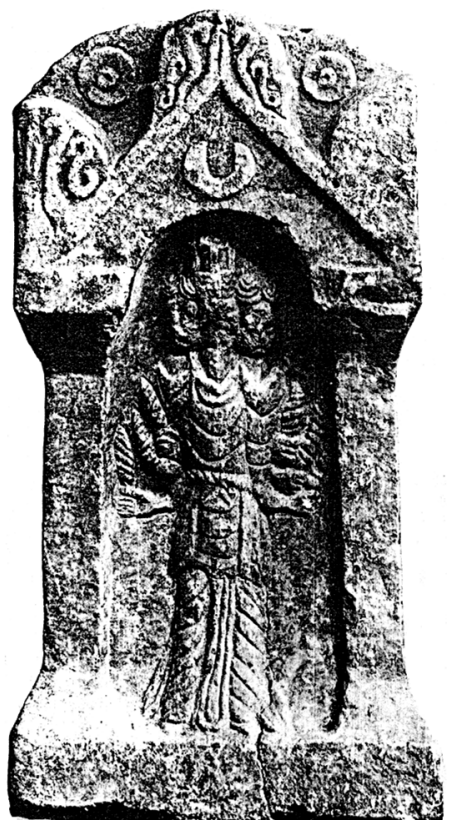

Fig. 15a: Mitropoulou 1978, 46 no. 59 fig. 75.

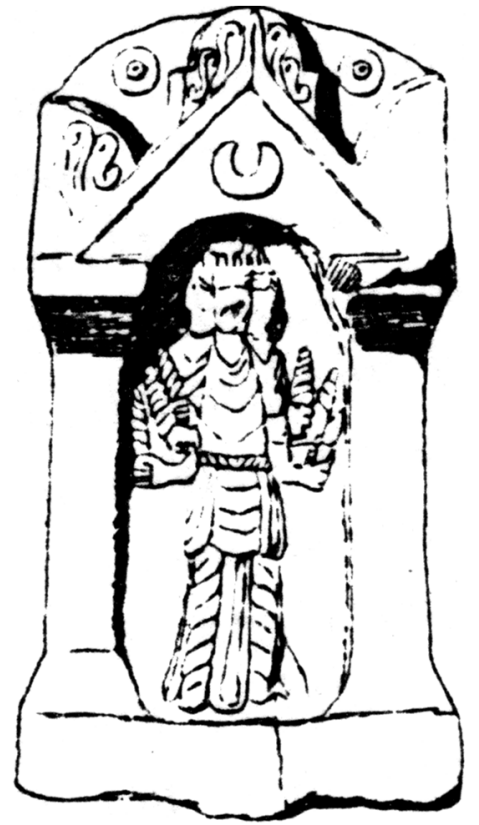

Fig. 15b: Conze 1891, 256 no. 688.

\section{A small Hecateion}

İncesu/Manisa (formerly: Gölde [Kollyda]). Keil and Premerstein recorded it in a church named

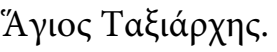

Ed: Keil - Premerstein II, 94 no. 4 (no photograph or drawings); Robert, Hellenica X, 1955, 115 fn. 3; Kraus 1960, 52 fn. 250; Greenewalt - Payne 1978, 44 fn. 15; Werth 2006, 403 no. 237. Other authors quoted from Keil and Premerstein.

Concerning this Hecateion, Keil and Premerstein merely note that 'three women figures stand back to back' and provide no further information. Robert mentions that it is a small relief. It is possible that it is identical with one of the Hecateia (or a relief) introduced in this paper.

\section{Votive Stele with a three-bodied Hecate Relief}

Find-spot: The precise find-spot is unknown, possibly from İncesu (formerly: Gölde [Kollyda]/Manisa). No information about the dimensions and material is provided by the publications.

The votive stele was copied in the church of 'Hagios Vlacoulos' in 1843 by Le Bas. On the stele is a three-bodied Hecate relief and its inscription survives in a very fragmentary state. Le Bas and Waddington did not describe the stele and did not provide any dimensions or photographs/drawings. Herrmann only referred to this limited information. The inscription is presumably a dedication to the goddess.

Ed.: Le Bas - Waddington 1870, 217 no. 677; Herrmann, TAM V 1, 119 no. 367.

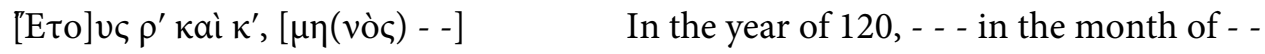

$$
\begin{aligned}
& 2 \text { [- - ]ос Mov[- - . - - - - ] son/daughter of Mou- - - }
\end{aligned}
$$


The year provided in the inscription is 120 . Since the Sullan Era was used in the region, one can securely date this inscription to the years A.D. 15-16.

\section{Grave stele of Glykonis which refers to Hecate (Fig. 18)}

White marble; housed in the National Museum in Warsaw; Inv. No.: 198813; Find-spot: The precise find-spot is unknown, but seems to be of northern-Lydia origin; $H .: 62 \mathrm{~cm} ; L .: 32 \mathrm{~cm} ; D .: 8 \mathrm{~cm}$; Lh.: $1,1-2 \mathrm{~cm}$.

Ed.: Wiegand 1905, 326-328; IGR IV, 621; Robert, Hellenica XI-XII, 1960, 579, fn. 5; Pfuhl - Möbius 1977, 210 no. 794 (no photo); Naour 1981, 20 fn. 36 and for the Hecate cult in North-eastern Lydia fn. 37; Robert, OMS V, 1989, 720 (on Hecate); Robert, OMS VII, 1990, 483-484 fn. 56 (Hecate); Strubbe 1997, 148-149 no. 215 (concerning the imprecation formula); Łajtar - Petzl 2003, 46-49 fig. 1.

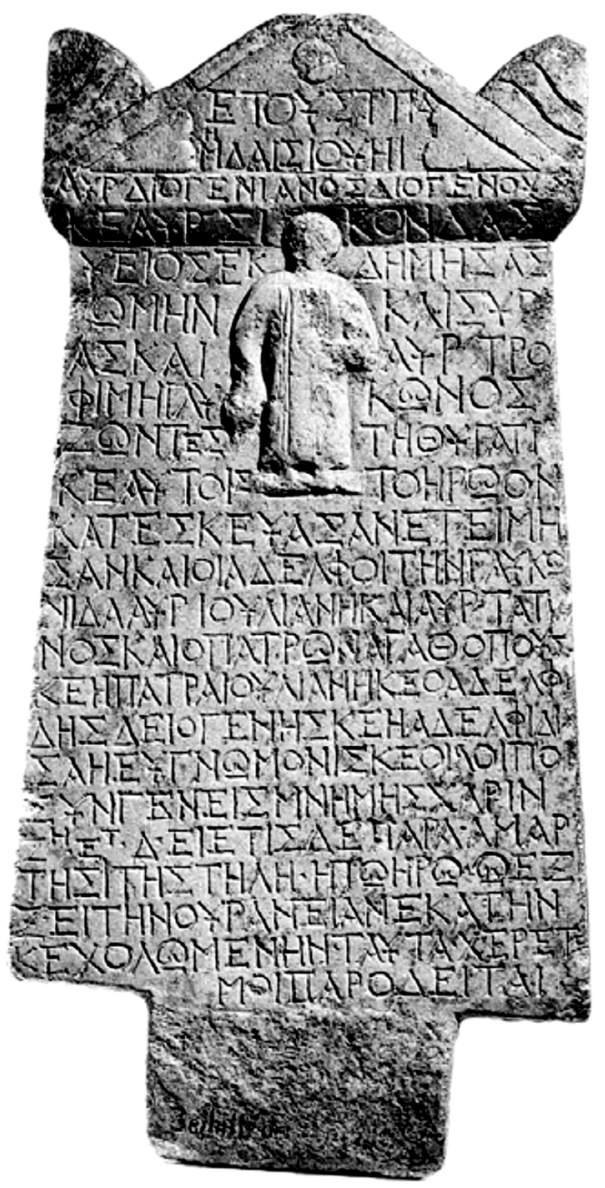

Fig. 18: Lajtar - Petzl 2003, 46-49 fig. 1: Grave stele of the 4 year old Glykonis and her parents.
For a rich bibliography providing valuable information about various issues of the inscriptions except for those treated here, see also Strubbe 1997, 148-149 and tajtar - Petzl 2003, $46 \mathrm{fn}$. 4. One can read the story of the way the stele was exported from Asia Minor and transferred to the National Museum in Warsaw in Lajtar - Petzl 2003, p. 46 (see also p. 50 for a Turkish summary).

The topmost acroterium of the stele with pediment is broken and missing. The shaft of the stele thickens down towards the base. The stele, which does not have a base, has a large dowel. The pediment is low and moulded by simple lines. The curved lines on the corner acroteria are stylized as plant decorations. On the top of the pediment a small patera is carved. In the inner sections of the stele are heart-shaped leaf ornaments. Right below the pediment is a relief of a standing person. This figure represents the daughter Glykonis mentioned in the inscription, who died at the age of four. All details of the figure are weathered and her head is placed on the lower profile of the pediment. She probably holds her toys (?) in her hands and the base upon which she put her feet is visible. Starting from the pediment, an inscription of 23 lines is thoroughly carved on the well-preserved stele. The first four lines are carved on the pediment. 
ह̌ंกขৎ $\tau \pi \delta^{\prime}$,

2

$\mu \eta$ (vòৎ) $\Delta$ aı бíov $\eta \iota^{\prime}$.

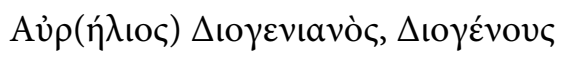

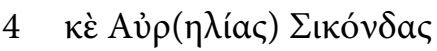

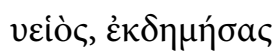

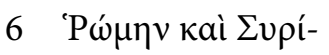

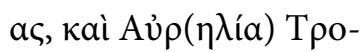

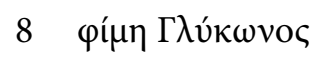

$\zeta \tilde{\omega} v \tau \varepsilon \varsigma \tau \tilde{\eta} \theta 0 \gamma \alpha \tau \rho \grave{i}$

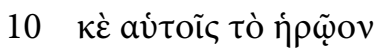

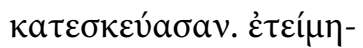

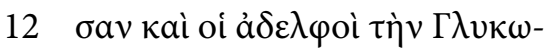

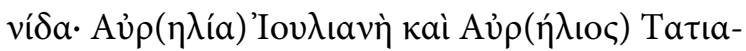

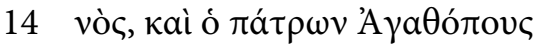

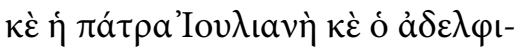

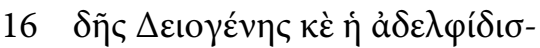

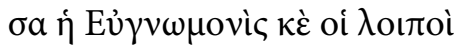

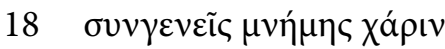

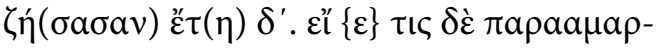

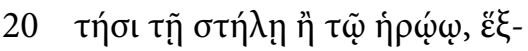

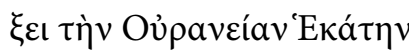

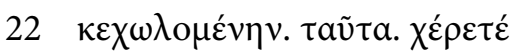

$\mu \mathrm{ol}, \pi \alpha \rho \circ \delta \varepsilon \tilde{\tau} \tau \alpha \mathrm{l}$.
In the year 384 , on $18^{\text {th }}$ day of the month Daisios.

Aurelius Diogenianos, son of Aurelius Diogenes and Aurelia Secunda, after travelling to Rome and to Syria. and Aurelia Trophime, daughter of Glykon, in their lifetime constructed the tomb for their daughter and for themselves. And the siblings also honoured the memory of Glykonis: Aurelia Iuliane and Aurelius Tatianos; and also her uncle Agathopous and her aunt Iuliane and her cousin Diogenes and her cousin Eugnomonis and the other relatives: (the deceased) lived four years. If anyone commits an offence against this stele or the tomb, he will incur the wrath of Urania Hecate. Such is life. Greet me, passers-by! ${ }^{11}$

${ }^{61}$ My translation is based on that of Łajtar - Petzl 2003, p. 50. 
The importance of this grave stele lies in the fact that the name of the goddess appears in the imprecation formula of the stele: 'If anyone commits an offence to this stele or the tomb, he will incur the wrath of Hecate upon himself. The goddess is mentioned as 'Ourania Hecate' in this inscription. L. Robert underlined the fact that in this case an epithet was used for Hecate that is mostly applied to Selene, see Robert, OMS V, 1989, 720: (' $\ldots$ il est intéressant qu'Hécate ici soit tirée du monde souterrain pour être Céleste. Elle est alors assimilée à Sélénè ...'). As Robert assumed that the find-spot of the inscription was around Uşak, he associated the imprecation formula in the inscription with the 'malédictions phrygiennes', see Robert, OMS VII, 1990, 483 fn. 56. In some inscriptions from Phrygia, one can indeed come across imprecation formulas where the name of the goddess is em-

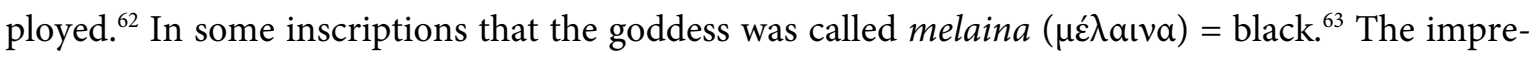
cation formula and the mentioning of the goddess (on Hecate, see Strubbe 1997, 149) in this inscription make us think that the stele was discovered in an area close to Phrygia. It is known that the north-eastern part of Lydia was under intense influence from Phrygia ${ }^{64}$ which may suggest that this stele can have a north-eastern Lydia origin. Be that as it may, Łajtar - Petzl $(2003,49)$ use this inscription as evidence for the scarce Hecate veneration in Lydia.

\section{Depictions of Hecate on Lydian coins}

Hecate is also depicted on coins of Asia Minor. In Lydia ${ }^{65}$ the cities of Philadelphia and Maionia minted coins with Hecate. ${ }^{66}$ L. Robert expressed his opinion of these coins. The identification of the coins having three-bodied depictions is obvious; ${ }^{67}$ less clear is the identification of coins with the depictions of only a single bodied-goddess. These are figures holding a torch in one hand and carrying a phiale or once again a torch on the other and there are no dogs accompanying them. Robert refuses the identification of the depictions on the coins introduced by Imhoof-Blumer ${ }^{68}$ as being of Hecate. ${ }^{69}$ I can support the justifiable criticism of Robert. As is seen above, the statuettes and reliefs documented in both Philadelphia and Maionia demonstrate that the goddess was depic-

${ }^{62}$ See Strubbe 1997, 96 no. 129; 112-116 no. 155; 130-131 no. 181 and possibly 255-256 no. 379; Lochman 2003, 90 fn. 188 .

${ }^{63}$ See for example Strubbe 1997, 130-131 no. 181; Lochman 2003, 90 fn. 188.

${ }^{64}$ See Naour 1981, 20 fn. 36; Lochman 2003, 198 fn. 16. See also above fn. 23.

${ }^{65}$ A group of coins depicting Hecate has been discovered in the city of Mastaura. Even though some sources locate Mastaura in the region of Lydia, it belongs to Carian-Phrygian borderlands (cf. Robert, Hellenica X, 1955, 115 fn. 4). Its coins are therefore not included in this study. M. Paz de Hoz likewise excluded the cults of Mastaura in her catalogue, cf. Paz de Hoz 1999, 7. For the most recent Mastauran coins (Kraus 1960, 167 no. 11) with the depictions of Hecate, see Werth 2006, catalogue no. 307; 452-454. Werth cites the oldest publications regarding these coins in the catalogue. On the Mastauran coins, see also Üreten 2005 and the paper of Nollé (2016) in this issue of Gephyra.

${ }^{66}$ Head states that the depiction of a goddess on an Attaleian coin in Lydia might be Selene or Hecate, see Head 1901, 28 no. 19 pl. IV 3. This coin is not included in the catalogue because I think that it does not have anything to do with Hecate. On the coins depicting Hecate/Selene in Lydia, see in general Greenewalt Payne 1978, 44 fn. 15.

${ }^{67}$ Robert, Hellenica X, 1955, 115 fn. 4, see here cat. no. 7.

${ }^{68}$ Imhoof-Blumer 1913, 13-14.

${ }^{69}$ Robert, ibid., 116 fn. 1. 
ted as being three-bodied, and this would also be expected on the coins struck in these cities. However, in my opinion, it is not possible to state with certainty that the goddess holding torches in both hands does not represent Hecate. Due to the fact that the monuments regarding Hecate are commonly dated to the $2^{\text {nd }}$ century A.D. or later, as is underlined above, these coins of both cities, which are dated to the reigns of Nero and Titus, could be the earliest evidence for the cult of Hecate if they really carry the depiction of the goddess. Except for these two cities, the existence of coins depicting Hecate in this region is uncertain. ${ }^{70} \mathrm{~A}$ small list of coins, belonging to Philadelphia ${ }^{71}$ and Maionia and which have been thought to carry Hecate depictions, is given below.

\section{Philadelphia}

1. (Reign of the emperor Nero) Imhoof-Blumer 1897, 122 no. 30 pl. 5,13; Imhoof-Blumer 1913, 13 no. 41 pl. 2,5; Robert, Hellenica X, 1955, 115-116 fn. 1; Kraus 1960, s. 30; Sarian, LIMC VI 1, no. 90; RPC I; Werth 2006, 486 no. 451.

2. (Reign of the emperor Titus) Imhoof-Blumer 1913, (Alte Kultbilder), 13-14 and Hekate von Maionia und Philadelphia: no. 42 pl. II, 6; ibid., Zur griechischen und römischen Münzkunde 127,7; RPC I; Werth 2006, 487-488 no. 455.

3. (Reign of the emperor Septimius Severus) Head 1901, 192, 34 pl. 21,13; Sarian, LIMC VI 1, 1007 no. 266 , pl. 671 no. 266 ; Werth 2006, 489 no. 459.

4. Imhoof-Blumer 1913 (Alte Kultbilder), 13-14 and Hekate von Maionia und Philadelphia: no. 41 lev. II, 5; Robert, Hellenica X, 1955, 116 fn. 1; Werth 2006, 494 no. 475.

5. (Roman Imperial Period) Head 1901, 191,30; RPC I, 3041.

\section{Maionia}

1. (Reign of the Emperor Nero) Imhoof-Blumer 1901, 176 no. 1 pl. 6,7; Imhoof-Blumer 1913, 13 no. 40 pl. 2,2-3; Robert, Hellenica X, 1955, 115-116 fn. 1; Sarian, LIMC VI 1, 996 no. 89; Werth 2006, 486 no. 450. Cf. Fleischer 1973, 304.

\section{Other monuments which might be related to Hecate}

It is probable that some monuments discovered in the Lydian Region are also related to Hecate. ${ }^{72}$ Since the name of the goddess is not given on these monuments and her iconography is not clearly

\footnotetext{
${ }^{70}$ A coin from Thyateira is said to carry Hecate depictions on it, see Imhoof-Blumer 1913, 14-15 no. 45.

${ }^{71}$ For the coins in Philadelphia, see also Doğan 2010, 112 no. 83-83 and p. 177.

${ }^{72}$ A white marble votive stele dedicated to a goddess named Nenenene was discovered in the Kula county of Manisa, see Keil - Premerstein I, 82, no. 178; Herrmann, TAM V 1, 89 no. 263 (with figure); Paz de Hoz 1999, 32-33; 261 no. 44,1. (H.: 35,5 cm; L.: 21,5 cm; D.: 5,5 cm; LH.: 1,6-1,2 cm). The inscription reads: A $\mu \mu \mathrm{t}$

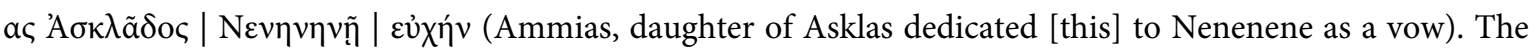
stele is broken at the top and has a relief of a standing woman. This figure most probably depicts the goddess Nenenene. To the right of the goddess is a depiction of a dog with its front legs raised up. Keil and Premerstein claim that Nenenene might be akin to Hecate due to this depiction of a dog. The authors date the stele to the $2^{\text {nd }} / 3^{\text {rd }}$ centuries A.D. from the style of lettering employed. Apart from this inscription, there is no other evidence regarding this goddess.
} 
evident, one cannot claim with certainty that they are Hecate monuments. Yet, with the intention of making the reader aware of their existence, I would like to briefly present these in this paper. ${ }^{73}$

A. Marble stele (In the inscription the stele is called ' $\beta \omega \mu$ óc'); since 1934 in the İzmir Museum (Transferred from Tire Museum); Inv. No.: 000-962; Findspot: Büyükkale (formerly: Büyük Kadife)/Tire/İzmir (South-west Lydia); H.: $80 \mathrm{~cm}$; L.: $59 \mathrm{~cm}$; D.: 12-13,5 cm; LH.: 1,4 cm.

Ed.: Jordanidis 1896, 471 no. 1; Keil - Premerstein III, 99 no. 148 fig. 61; Robert, Hellenica X, 1955, 117 pl. XIX 1; Greenewalt - Payne (1978, 44 fn. 15) mention this stele; IEphesos VII 1, 171 no. 3228; Werth 2006, 482 no. 438; Aybek et al. 2009, 137 no. 120.

The front side of a large, marble plaque is carved in relief in the form of a stele with pediment (see the figures below). The left side of the stele widens downward and thereby wins a curved appearance. In the low pediment a large patera is depicted. The first two lines of the inscription are carved around the patera, the third line is carved on the horizontal profile of the pediment. The shaft of the stele is framed by a thick moulding and figures are carved in relief in the middle of it. The goddess wears a polos and holds a lighted torch in her right hand, while in her left arm she holds a cornucopia (horn of plenty). She wears a chiton and a himation. The snake coiling around the lower part of the torch drinks something from the vessel on the small altar depicted to the right of the goddess. On the left side of the goddess there is a dog sitting and turning its head towards the goddess. The remaining three lines of the inscription are carved beneath the relief. From its inscription, Keil and Premerstein date this stele to the $2^{\text {nd }}$ century A.D.

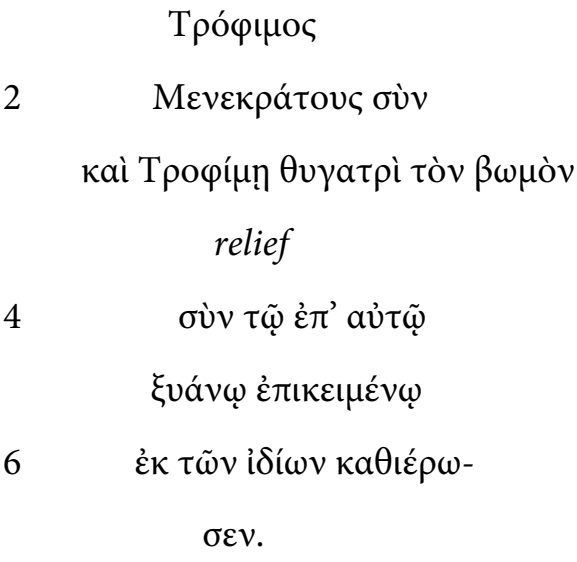

Trophimos, son of
Menekrates, together
with his daughter Trophime,
dedicated this altar
together with
the relief on it
at their own expenses.

Robert mentioned this stele when he discussed the cult of Hecate in Lydia, but did not explicitly identify the figure with Hecate. According to Keil and Premerstein, it may depict either Demeter or Kore. Werth, on the other hand, believes that the goddess depicted in the relief is the one-bodied Hecate and included it in his catalogue.

\footnotetext{
${ }^{73}$ In a confession inscription from Maionia, a goddess whose name is not given in the text might possibly be Hecate. One can easily deduce from the monuments in the catalogue that Hecate was worshipped in Maionia (cat. nos. 4,5 and 6). For the inscription, see Malay - Ricl 2006.
} 


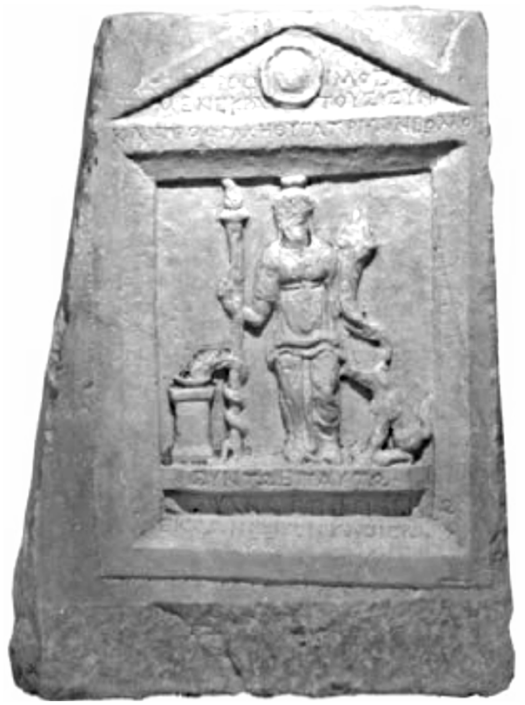

Aybek et al. 2009, 137 no. 120.

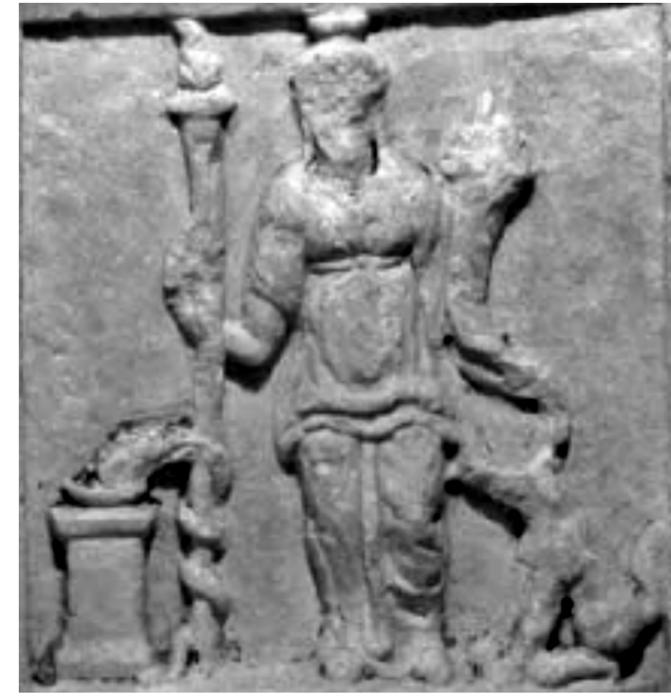

Detail from Aybek et al. 2009, 137 no. 120

B. Marble altar: In the museum of Manisa; Inv. No.: 6398; Find-spot: The find-spot as well as its provenance are unknown, possibly of Lydian origin; the publication quotes no dimensions of the monument.

Ed.: Malay 1994, 66-67 no. 161 fig. 55 A-D.

The altar is decorated with reliefs on all its sides; on top there is a low capital, at the bottom a socle (see the figure). On the front side (fig. 55A), directly beneath the capital are the remains of a frag-

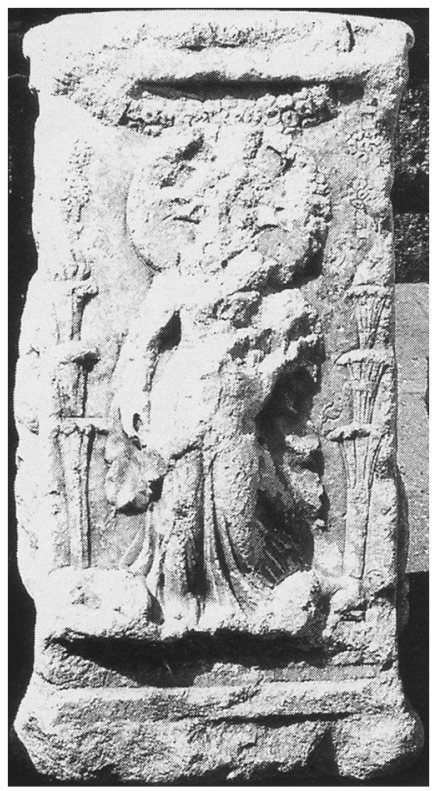

Malay 1994, 66-67 no. $161 \mathrm{fig}$. $55 \mathrm{~B}$. mentary inscription consisting of three lines. Some of the figures, being much eroded, are unidentifiable. At the back of the altar (side B) there is a standing goddess. The face of the figure, depicted between two burning and three-layered torches, is chipped. She wears a long, loose dress and carries a polos on her head. Behind her shoulders is the depiction of a large crescent moon. At each foot of the goddess there lies a dog curled up on the ground. Around the goddess' hair an aureole (?) is pictured. There is a garland above the head and beneath the capital of the altar. Although the goddess does not have three bodies, the torches, dogs and also the crescent moon suggest that she may well represent Hecate or Hecate-Selene.

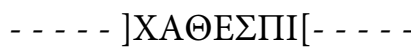

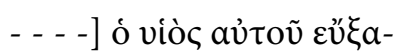

$$
\begin{aligned}
& \text { To. } ه
\end{aligned}
$$

It is possibly a votive inscription and bears the name of the goddess to whom the inscription was dedicated. In the editio princeps H. Malay notes on p. 67: 'To be fully published by S. Hijmans who hesitatingly dates it to the second century A. D.' 


\section{Bibliography}

Akyürek Şahin 2006

Akyürek Şahin 2007

Akyürek Şahin 2011

Altun 2008

Aybek et al 2009

Berg 1974

Berger-Doer 1997

Brahms 1994

Brehm 2002

Buckler - Calder, MAMA VI

Buckler - Robinson 1932

Chrysostomou 1998

Conze 1891

Cook 1964

Crawford - Greenewalt 2010

Doğan 2010

Drexler 1894-1897
N. E. Akyürek Şahin, Anadolu Hekate Korpusu ve Çeşitli Müzelerde Hekate Üzerinde Çalışmalar. Bir Ön Rapor, Arkeoloji ve Sanat Dergisi 121, 2006, 59-66.

N. E. Akyürek Şahin, Neue Votivsteine aus dem Museum von Afyon, Gephyra 4, 2007, 59-115.

N. E. Akyürek Şahin, Antalya Müzesi'nden İki Hekateion, Adalya XIV, 2011, 237-257.

A. Altun, Nikaia Hekateion'u, in: T. Tarhan - A. Tibet - E. Konyar (ed.), Muhibbe Darga Armağanı. Sadberk Hanım Müzesi Yayınları, İstanbul 2008, 81-86.

S. Aybek - M. Tuna - M. Atıcı, İzmir Tarih ve Sanat Müzesi Heykel Kataloğu, Ankara 2009.

W. Berg, Hecate: Greek or “Anatolian”?, Numen 21, 1974, 128-140.

G. Berger-Doer, LIMC VIII, 1997, 545-549, s.v. canes.

T. Brahms, Archaismus. Untersuchungen zu Funktion und Bedeutung archaistischer Kunst in der Klassik und im Hellenismus (Europäische Hochschulschriften 28, Archäologie 53), Frankfurt 1994.

O. Brehm, Artemis, Hekate oder Persephone? Überlegungen zur jugendlichen Göttin auf einem spätklassischen Relief aus Kyzikos, in: E. Schwertheim (ed.), Studien zum antiken Kleinasien V, Bonn 2002, 25-32 (AMS 44).

W. H. Buckler - W. M. Calder, Monuments and Documents from Phrygia and Caria (MAMA VI), Manchester 1939.

W. H. Buckler - D. M. Robinson, Greek and Latin Inscriptions (Sardis VII 1), Leiden 1932.

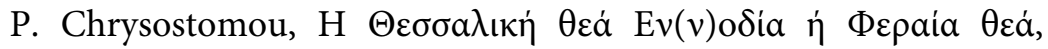
Athens 1998.

A. Conze, Königliche Museen zu Berlin. Beschreibung der antiken Skulpturen mit Ausschluss der pergamenischen Fundstücke, Berlin 1891.

A. B. Cook, Zeus. A Study in Ancient Religion, Volume I. Zeus god of the bright sky, New York 1964.

H. Crawford - Jr. Greenewalt, Lidya Tanriları. The Gods of Lydia, in: N. D. Cahill (ed.), Lidyalılar ve Dünyaları. The Lydians and Their World, Istanbul 2010, 233-246.

C. Doğan, Philadelphia Sikkeleri, Aydın 2010 (Adnan Menderes University - Unpublished Diss.).

W. Drexler, in: Roscher, ML II 2, Leipzig 1894-1897 (Reprint: Hil- 
Drew-Bear et al. 1999

Durugönül et al. 2015

Eckstein 1965

Filges 1999

Fleischer 1973

Frel 1967/68

Gauthier 1989

Greenewalt - Payne 1978

Habicht 1969

Hanfmann 1983

Hanfmann - Ramage 1977

Hanfmann - Waldbaum 1975

Harrison 1965

Head 1901

Head 1906

Heckenbach 1912

Herrmann 1962

Herrmann - Polatkan 1961 desheim 1965), 2687-2770, s.v. Men.

Th. Drew-Bear - Ch. M. Thomas - M. Yıldizturan, Phrygian Votive Steles. The Museum of Anatolian Civilizations, Ankara 1999.

S. Durugönül - D. Kaplan - M. Dinç - U. Tepebaş, Manisa Müzesi Heykeltraşlık Eserleri (Kilikia Arkeolojisini Araştırma Merkezi Yayınları 3), İstanbul 2015.

F. Eckstein, Das Hekateion in der British School zu Athen, in: Antike Plastik IV, 1965, 27-36.

A. Filges, Marmorstatuetten aus Kleinasien. Zu Ikonographie, Funktion und Produktion antoninischer, severischer und späterer Idealplastik, IstMitt 49, 1999, 377-430.

R. Fleischer, Artemis von Ephesos und verwandte Kultstatuen aus Anatolien und Syrien (EPRO 35), Leiden 1973.

J. Frel, in: Rodin collectionneur. Musée Rodin, Paris 1967-1968.

$\mathrm{Ph}$. Gauthier, Nouvelles Inscriptions de Sardes II, Geneva-Paris 1989.

C. H. Greenewalt - S. Payne, Ritual Dinners in Early Historic Sardis, Berkeley-Los Angeles 1978.

C. Habicht, Die Inschriften des Asklepieions, Berlin 1969.

G. M. A. Hanfmann, On the Gods of Lydian Sardis, in: R. M. Boehmer (ed.), Beiträge zur Altertumskunde Kleinasiens. Festschrift für K. Bittel, Mainz 1983, 219-231.

G. M. A. Hanfmann - N. H. Ramage, Stone Sculpture; Sardis Report 2, Cambridge 1977.

G. M. A. Hanfmann - J. C. Waldbaum et alii, A Survey of Sardis and the Major Monuments Outside the City Walls. Archaelogical Exploration of Sardis Report 1, Cambridge, MA 1975.

E. B. Harrison, III. Hekataia. Archaic and Archaistic Sculpture (Princeton 1965) (The Athenian Agora XI), 86-107.

B. V. Head, A Catalogue of the Greek Coins in the British Museum (BMC). Coins of Lydia, London 1901 (Reprint: Bologna 1964).

B. V. Head, A Catalogue of the Greek Coins in the British Museum (BMC). Coins of Phrygia, Londra 1906 (Reprint: Bologna 1964).

J. Heckenbach, RE VII 2, 1912, 2769-2782, s.v. Hekate.

P. Hermann, Ergebnisse einer Reise in Nordostlydien (Denkschriften der österreichischen Akademie der Wissenschaften 80), Vienna 1962.

P. Herrmann - K. Z. Polatkan, Grab- und Votivstelen aus dem nordöstlichen Lydien im Museum von Manisa, AnzWien 98, 1961, 
119-127.

Herrmann - Polatkan 1969 P. Herrmann - K. Z. Polatkan, Das Testament des Epikrates und andere neue Inschriften aus dem Museum von Manisa, Vienna 1969.

Herrmann, TAM V 1

Herrmann, TAM V 2

Herrmann - Varinlioğlu 1984

Höfer 1909-1915

Imhoof-Blumer 1897

Imhoof-Blumer 1901

Imhoof-Blumer 1913

IEphesos VII 1

IMagnesia

ITralleis

Jessen 1905

Johnston 1990

Johnston 1998

Jordanidis 1896

Kehl 1988

Keil 1923

Keil - Premerstein I

Keil - Premerstein II
P. Herrmann, Tituli Asiae Minors V. Tituli Lydiae 1, Vienna 1981.

P. Herrmann, Tituli Asiae Minors V. Tituli Lydiae 2, Vienna 1989.

P. Herrmann - E. Varinlioğlu, Theoi Pereudenoi. Eine Gruppe von Weihungen und Sühneinschriften aus der Katakekaumene, Epigr. Anat. 3, 1984, 1-18.

O. Höfer, in: Roscher ML IV, Leipzig 1909-1915 (Reprint: Hildesheim 1965), 1236-1247, s.v. Soteira.

F. Imhoof-Blumer, Lydische Stadtmünzen. Neue Untersuchungen, Geneva-Leipzig 1897.

F. Imhoof-Blumer, Kleinasiatische Münzen, Vienna 1901.

F. Imhoof-Blumer, Beiträge zur Erklärung griechischer Münztypen, Nomisma 8, 1913, 1-22.

R. Meriç - R. Merkelbach - J. Nollé - S. Şahin, Die Inschriften von Ephesos. Teil VII 1, Nr. 3001-3005 (Repertorium) (IK 17,1), Bonn 1981.

Th. Ihnken, Die Inschriften von Magnesia am Sipylos (IK 8), Bonn 1978.

F. B. Poljakov, Die Inschriften von Tralleis und Nysa I. Die Inschriften von Tralleis (IK 31,1), Bonn 1989.

O. Jessen, RE 5.2 (1905), 2634-2635 s.v. Enodia.

S. I. Johnston, Hekate Soteira. A Study of Hekate's Roles in the Chaldean Oracles and Related Literature (American Classical Studies 21), Atlanta, Georgia 1990.

S. I. Johnston, DNP 5, 1998, 267-270 s.v. Hekate.

E. Jordanidis, Funde, AM 21, 1896, 471.

A. Kehl, RAC 14, 1988, col. 310-338 s.v. Hekate.

J. Keil, Die Kulte Lydiens, in: W. H. Buckler - W. M. Calder (eds.), Anatolian Studies presented to Sir W. M. Ramsay, Manchester 1923, 239-266.

J. Keil - A. von Premerstein, Bericht über eine Reise in Lydien und der südlichen Aiolis ausgeführt 1906, DenkschrWien 53, 2/1, Vienna 1908.

J. Keil - A. von Premerstein, Bericht über eine Reise in Lydien ausgeführt 1908, Denkschr Wien 54, 2, Vienna 1911. 
Keil - Premerstein III

Kraus 1960

Łajtar - Petzl 2003

Lane 1971

Lautwein 2009

Le Bas - Waddington 1870

Lochman 1990,1

Lochman 1990,2

Lochman 2003

Malay 1994

Malay 1999

Malay - Ricl 2006

Martin 2003

Merkelbach - Stauber 1998

Meriç 1987

Meyer 1996
J. Keil - A. von Premerstein, Bericht über eine dritte Reise in Lydien und den angrenzenden Gebieten Ioniens, ausgeführt 1911, Denkschr Wien 57, 1, Vienna 1914.

T. Kraus, Hekate. Studien zu Wesen und Bild der Göttin in Kleinasien und Griechenland, Heidelberg 1960.

A. Łajtar - G. Petzl, Eine lydische Familie aus der zweiten Hälfte des 3. Jahrhunderts n. Chr. (zu Epigr. Anatol. 34, 2002, 99ff., Nr. 3 und IGR IV 621), Epigr. Anat. 36, 2003, 45-50.

E. N. Lane, Corpus monumentorum religionis dei Menis (CMRDM). I. The monuments and inscriptions (EPRO 19.1), Leiden 1971.

T. Lautwein, Hekate. Die dunkle Göttin. Geschichte und Gegenwart, Rudolstadt 2009.

$\mathrm{Ph}$. Le Bas - W. H. Waddington, Voyage archéologique en Grèce et en Asie Mineure. Inscriptions III, Paris 1870 (Reprint: Hildesheim 1972).

T. Lochman, Une stèle phrygienne, in: Deux acquisitions d'archéologie au musée Calvet d'Avignon, RLouvre 6, 1990, 455-461.

T. Lochman, Eine Gruppe spätrömischer Grabsteine aus Phrygien, in: E. Berger (ed.), Antike Kunstwerke aus der Sammlung Ludwig III. Die Skulpturen, Mainz 1990, 453-508.

T. Lochman, Studien zu kaiserzeitlichen Grab- und Votivereliefs aus Phrygien, Basel 2003.

H. Malay, Greek and Latin Inscriptions in the Manisa Museum (ETAM 19), Vienna 1994.

H. Malay, Researches in Lydia, Mysia and Aiolis (ETAM 23), Vienna 1999.

H. Malay - M. Ricl, A New Dedication from the Katakekaumene, Epigr. Anat. 39, 2006, 84-86.

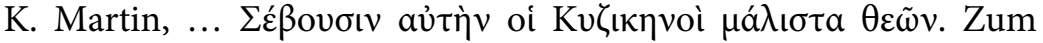
Kult der Kore Soteira im kaizerzeitlichen Kyzikos, in: E. Schwertheim - E. Winter (ed.), Religion und Region. Götter und Kulte aus dem östlichen Mittelmeerraum (AMS 45), Bonn 2003, 115-158.

R. Merkelbach - J. Stauber, Steinepigramme aus dem griechischen Osten I. Die Westküste Kleinasiens von Knidios bis Ilion, StuttgartLeipzig 1998.

R. Meriç, 1985 Yılı Alaşehir Kazı Çalışmaları, VIII. KST II, 1987, 259-271.

M. Meyer, "Neue" Bilder. Zur Verwendung und zum Verständnis von bildlichen Darstellungen in der Levante, in: B. Funck (ed.), 
Meyer 2006

Michon 1892

Mitropoulou 1978

Müller 1915

Naour 1981

Naour 1983

Nilsson 1906

Nilsson 1948

Nilsson 1955

Nollé 2010

Nollé 2016

Orth 1913

Özgan 1999

Paz de Hoz 1999

Petersen 1880

Petersen 1881

Petzl 1994

Petzl 1995
Hellenismus. Beiträge zur Erforschung von Akkulturation und politischer Ordnung in den Staaten des hellenistischen Zeitalters, Akten des Internationalen Hellenismus-Kolloquium, 9-14 März 1994 in Berlin, Tübingen 1996, 243-254.

M. Meyer, Die Personifikation der Stadt Antiocheia: ein neues Bild für eine neue Gottheit, Berlin 2006.

E. Michon, Groupes de la triple Hécate au Musée du Louvre, Mélanges d'archéologie et d'histoire 12, 1892, 407-424.

E. Mitropoulou, Triple Hekate Mainly on Votive Reliefs, Coins, Gems and Amulets, Athens 1978.

V. K. Müller, Der Polos, die griechische Götterkrone, Berlin 1915.

Chr. Naour, Inscriptions du Moyen Hermos, ZPE 44, 1981, 11-44.

Chr. Naour, Nouvelles inscriptions du Moyen Hermos, Epigr. Anat. 2, 1983, 107-140.

M. P. Nilsson, Griechische Feste von religiöser Bedeutung mit Ausschluss der Attischen, Leipzig 1906 (Reprint: 1995).

M. P. Nilsson, Die Religion in den griechischen Zauberpapyri, Lund 1948.

M. P. Nilsson, Geschichte der griechischen Religion I. Die Religion Griechenlands bis auf die griechische Weltherrschaft, München 1955 (Reprint: 1976).

J. Nollé, Beiträge zur kleinasiatischen Münzkunde und Geschichte 10. Kadwenische Münzbilder, Gephyra 7, 2010, 71-126.

J. Nollé, Beiträge zur kleinasiatischen Münzkunde und Geschichte: 12. Mastaura am Fuße der Mesogis. Überlegungen zu den Patriatraditionen einer wenig bekannten antiken Polis, Gephyra 13, 2016, 49-82.

F. Orth, RE VIII 2, 1913, 2540-2582, s.v. Hund.

R. Özgan, Die Skulpturen von Stratonikeia, Bonn 1999 (AMS 32).

M. Paz de Hoz, Die lydischen Kulte im Lichte der griechischen Inschriften, Bonn 1999 (AMS 36).

E. Petersen, Die Dreigestaltige Hekate I, AEM 4, 1880, 140-174.

E. Petersen, Die Dreigestaltige Hekate (Fortsetzung) II, AEM 5, $1881,1-84$.

G. Petzl, Die Beichtinschriften Westkleinasiens, Bonn 1994 (Epigr. Anat. 22).

G. Petzl, Ländliche Religiosität in Lydien, in: E. Schwertheim (ed.), Forschungen in Lydien, Bonn 1995, 37-48 (AMS 17). 
Petzl 2002

Petzl 2003

Pfuhl - Möbius 1977

Pfuhl - Möbius 1979

RLouvre

Robert, Hellenica

Robert, OMS

Robert 1964

Roloff 1994

Roscher ML

Roscher 1886-1890

RPC

Sarian, LIMC VI 1

Scholz 1937

Schuler 2002

Steuding 1884-1890

Stiegler 1967

Strubbe 1997
G. Petzl, Zum religiösen Leben im westlichen Kleinasien. Einflüsse und Wechselwirkungen, in: H. Blum - B. Faist - P. Pfälzner - A.M. Wittke (ed.), Brückenland Anatolien? Ursachen, Extensität und Modi des Kulturaustausches zwischen Anatolien und seinen Nachbarn, Tübingen 2002, 381-391.

G. Petzl, Zum religiösen Leben im westlichen Kleinasien. Einflüsse und Wechselwirkungen, in: E. Schwertheim - W. Winter (ed.), Religion und Region. Götter und Kulte aus dem östlichen Mittelmeerraum, Bonn 2003, 93-101 (AMS 45).

E. Pfuhl - H. Möbius, Die ostgriechischen Grabreliefs I, Mainz 1977.

E. Pfuhl - H. Möbius, Die ostgriechischen Grabreliefs II, Mainz 1979.

Revue du Louvre. La revue des musées de France.

L. Robert, Hellenica. Recueil d'épigraphie, de numismatique et d'antiquités grecques I-XIII, Paris 1942-1965.

L. Robert, Opera Minora Selecta I-VII, Amsterdam 1969-1990.

L. Robert, Nouvelles inscriptions de Sardes I. Paris 1964.

K.-H. Roloff, Lexikon der Antiken Welt 2 (H-Q) (1994), 1230, s.v. Hekate.

W. H. Roscher (ed.), Ausführliches Lexikon der griechischen und römischen Mythologie I-VI, Leipzig 1884-1937 (Reprint: Hildesheim 1965).

H. W. Roscher, in: Roscher ML I, Leipzig 1884-1890 (Reprint: Hildesheim 1965), 1900-1910, s.v. Hekate in der Kunst.

Roman Provincial Coinage.

H. Sarian, LIMC VI 1, 1992, 985-1018, s.v. Hekate (Addenda) (lev. VI 2, 654-673).

H. Scholz, Der Hund in der griechisch-römischen Magie und Religion, Berlin 1937.

Chr. Schuler, Rezension: María Paz de Hoz, Die lydischen Kulte im Lichte der griechischen Inschriften (AMS 36), Bonn 1999, Gnomon $74 / 5,2002,458-460$.

H. Steuding, in: Roscher ML I, Leipzig 1884-1890 (Hildesheim 1965), 1885-1900, s.v. Hekate.

H. Stiegler, KlP 2 (1967), 982-983 s.v. Hekate.

J. Strubbe, Arai Epitymbioi. Imprecations against Desecrators of the Grave in the Greek Epitaphs of Asia Minor. A Catalogue (IK 52), Bonn 1997. 
Şahin - Taşlıalan 2010

Usman Anabolu 1987

Usman Anabolu 1988

Usman Anabolu 1989

Üreten 2005

Varinlioğlu, Uşak

Vollkommer 1992

Werth 2006

West 1966

Willers 1990

Wiegand 1905

Zeleny 1999
M. Şahin - M. Taşlıalan, Smyrna Agorası Heykeltraşlık Buluntular1, Olba XVIII, 2010, 175-240.

M. Usman Anabolu, Manisa Müzesi'ndeki Üçlü, in: H. R. Çongur (ed.), Remzi Oğuz Arık Armağanı, 1987, 47-50.

M. Usman Anabolu, Batı Anadolu'da Bulunan Demeter ve Khitonien Tanrılar Tapınakları, AST 6, 1988, 121-139.

M. Usman Anabolu, İzmir Arkeoloji Müzesi'nin Deposunda Bulunan Yedi Hekataion (Üç Vücutlu Hekate Heykeli), in: C. Bayburtluoğlu (ed.), Ekrem Akurgal Armağanı, Anadolu (Anatolia) 22, 1981/83, Ankara 1989, 329-335.

H. Üreten, Bir Grup Sikkenin Işı̆̆ında Mastaura Kenti Tanrı ve Kültleri, Çankaya Üniversitesi, Fen-Edebiyat Fakültesi, Journal of Arts and Sciences 4, 2005, 129-142.

E. Varinlioğlu, Greek and Latin Inscriptions in the Uşak Archaeological Museum (Gephyra Monographies), İstanbul 2016 (in preparation).

R. Vollkommer, LIMC VI, 1992, 462-473 lev. 239-255, s.v. Men.

N. Werth, Hekate. Untersuchungen zur dreigestaltigen Göttin, Hamburg 2006 (Antiquitates 37).

M. L. West, Hesiod Theogony, Oxford 1966.

D. Willers, Hellenistische und Römische Idealplastik (Nr. 246-250), in: E. Berger (ed.), Antike Kustwerke aus der Sammlung Ludwig III (Skulpturen), Basel 1990, 301-307.

Th. Wiegand, Inschriften aus Kleinasien, AM 30, 1905, 323-330.

K. Zeleny, Die Göttin Hekate in den Historiae deorum gentilium des Lilius Gregorius Gyraldus (Basel 1548) unter besonderer Berücksichtigung der Rezeption Hekates in humanistischen Handbüchern und Kommentaren des 16. Jahrhunderts. Diplomarbeit zur Erlangung des Magistergrades der Philosophie, Vienna 1999. 


\section{Lydia’da Hekate Kültü: Manisa Müzesi’nden Eserler \\ Özet}

Bu makalede Manisa Müzesi'nde bulunan eserlerin ışığında Lydia'daki Hekate kültü incelenmektedir. Eserler bir katalogda bir araya getirilmiştir ve kült çerçevesinde arkeolojik ve stilistik açılardan incelenmektedir. Katalog beş bölüme ayrılmıştır: Birinci kısımda müzedeki buluntu yerleri kesin bilinen eserler; ikinci kısımda ise müzedeki buluntu yerleri bilinmeyen eserler incelenmektedir. Üçüncü kısımda müze dışındaki eserler; dördüncü kısımda sikkeler ve beşinci kısımda ise kültle ilgili olabilecek iki eser derlenmiştir. Lydia'da Hekate ile ilgili bugüne kadar sadece iki yazıt (no. 6 ve 8) ele geçmiştir. Yazıtların dışında bölgede üzerlerinde Hekateion betimli steller ve kabartmalar bulunmuştur. Yaklaşık yirmi civarındaki bu buluntular bölgede Hekate'nin varlığını açık biçimde ortaya koymaktadır. Eserlerin buluntu yerleri Philadelphia, Maionia, Satala, Thyateira, Sardis, Kollyda ve Sidas'tır. Buluntu durumuna göre Philadelphia ve Maionia'da yerel tapınaklar veya kült yerlerinin varlığından söz edilebilir. Makalede incelenen eserler tanrıçanın Lydia’nın her yerinde değil de, daha çok doğu bölgelerinde (Mysia Abbaïtis'in güneyi) yaygın tapınım gördügüne işaret etmektedir. Bu sonuç Lydia'nın doğu bölgelerinin Hekate kültünün yoğun olduğu Phrygia bölgesi ile komşu olmasına ve oradan etkilenmesine bağlanmaktadır. Lydia'nın Hellenleşmiş batı bölgesinde Hekate kültünün son derece sinırlı belgelenmesi, doğu kesimlerde Hekate adıyla tapınım gören tanrıçanın, tıpkı Phrygia'da olduğu gibi, kökende yerli bir Anadolu tanrıçasının Yunanlaşmış şekli olduğunu da düşündürmektedir. Makalede tanıtılan tüm eserler olasılıkla İ. S. 2. yüzyıla ait olmalıdır.

Anahtar Sözcükler: Hekate; Lydia; Manisa Müzesi; Hekateion; Mysia Abbaïtis.

\section{The Cult of Hecate in Lydia: Evidence from the Manisa Museum}

\section{Abstract}

In this article, the cult of Hecate in Lydia is examined on the basis of both the Hecate monuments housed in the Manisa Museum and those whose Lydian origin is asserted by publications. The monuments have been compiled in a catalogue and described archaeologically; they are commented on from the point of view of their significance for the cult of Hecate in Lydia. The catalogue is divided into 5 parts: 1 . The monuments whose provenance is established, 2 . The monuments whose provenance remains unknown, 3. The monuments outside the museum, 4. Coins, 5. Two other monuments that may be related to Hecate. Till now only two inscriptions concerning the cult have been attested in Lydia (see cat. no. 6 and 8). Apart from the inscriptions, there are Hecateia and stelai and reliefs which depict the goddess. At the end we can state that the worship of Hecate is not particularly prevalent in Lydia. However, nearly 20 examples provide evidence for the existence of the goddess' veneration in this region. Their find spots are Philadelphia, Maionia, Satala, Thyateira, Sardis, Kollyda and Sidas. By relying on their provenance, one can suggest that there were cultic places or local temples in the cities of Philadelphia and Maionia, and even in the countryside of Thyateira. We can learn from these monuments that the goddess was not worshipped in the whole of Lydia, but especially in the eastern parts of the region (north-western Lydian, i.e. the south of Mysia Abbaitis). It is argued that this situation can be explained by the influences of Phrygian cult and culture on Lydia. In the west of Lydia, where this influence was not so strong and where Hellenization was very extensive, evidence for the cult of Hecate was quite scarce. Nearly all the monuments in this article date from the $2^{\text {nd }}$ century A.D.

Keywords: Hecate; Lydia; Manisa Museum; Hecateion; Mysia Abbaïtis. 